\section{FIELDWALKED SITES}

Sites are listed in alphabetical order. See the maps below for location (Illus 6.1). The grid references refer to the north-east point of a field, bearing in mind that fields are often misshapen and rarely lie according to the compass. A total of 42 fields are covered here, from which over 11,000 lithics were recovered, representing at least 15 archaeological sites and a span of human activity covering some 10,000 years from around 12,000 в to $c 2000$ BC. Finds from the Late Upper Palaeolithic, Mesolithic, Neolithic and Bronze Age were present.

\subsection{Balbridie}

\subsubsection{Balbridie 1 (BB1)}

NGR: NO 7386095956

$45 \mathrm{~m}$ OD

4.89 hectares, $70-80$ pieces per hectare

Walked 10 March 2019, cold and frosty but sunny, 18 walkers, $2 \mathrm{~m}$ transects

Existing records from the field: a lithic scatter; and a cropmark of a possible ring ditch

Canmore: NO79NW 13; NO79NW 20

Aberdeenshire Historic Environment Record: NO79NW0010; NO79NW0018

The field sits on the Camphill Terrace on the southern bank of the river. A total of 326 lithics were found (Table 6.1), predominantly across the northern half of the field (Illus 6.2) and generally aligned along two palaeochannels running parallel to the river and visible in the satellite imagery, raising the possibility that the human activity was focused between the palaeochannels.

The lithic assemblage indicates activity in both the Late Mesolithic and the Neolithic. Most of the cores are single-platform cores, but there is a mix of other types as well. While the single leaf point and the knife forms suggest an Early Neolithic element to the site, there are also elements of Late Neolithic flint working, such as the bipolar cores. The assemblage is likely to derive from both the manufacture and the use of stone tools.

One blade from the site has been singled out for further study. A small blade of translucent honeycoloured flint was notable both for the fine quality of the raw material and for a distinctive black band running through the middle of the piece (Illus 6.3). A small patch of reddish adhesion on the left side prompted analysis at the York Experimental Archaeology Research Centre to investigate the nature of the material, but it was not possible to extract organic material for the identification of the adhesion. Microscopic analysis of the blade by Jess Bates revealed well-developed polish running perpendicular to the edge of the flint with some fine striations (Illus 6.4). As the polish was not particularly invasive it is interpreted as fairly short-term use for scraping plant material, perhaps soft green wood. An activity such as whittling might well result in this sort of polish, though other activities would have been available (Bates, pers comm). This blade, with its black central banding, is remarkably similar to a blade from the Mesolithic site of Star Carr in Yorkshire (Illus 6.5; Milner et al 2018).

\subsubsection{Balbridie East (EB1; EB2; EB3)}

EB1, NGR: NO 74658 95848; 7.3 hectares; 60-70 pieces per hectare

EB2, NGR: NO 74787 95802; 1.18 hectares; 50-60 pieces per hectare

EB3, NGR: NO 74799 95764; 1.04 hectares; 10-20 pieces per hectare

c $40 \mathrm{~m}$ OD

Walked 15 April 2018, dry and sunny weather, 21 walkers, $2 \mathrm{~m}$ transects

Aberdeenshire Historic Environment Record: NO79NW0124

The three fields at East Balbridie (Illus 6.6) lie on the Camphill Terrace and were selected for investigation due to their proximity to the lithic scatter site at Milton Cottage, part of the larger spread of lithics at Crathes, which lies on the opposite bank of the River Dee. A total of 518 lithics was found (Tables 6.2, 6.3 \& 6.4), spread widely across the fields but with a higher concentration of material towards the centre in EB2 (Illus 6.7). Together these fields have evidence for activity from the Mesolithic into the Neolithic. While there are some Late Neolithic types, notably the bipolar cores, and a bifacial piece, most of the evidence is likely to be Mesolithic or Early Neolithic. Most of the assemblage is flint, but it is supplemented by a few pieces of quartz. 


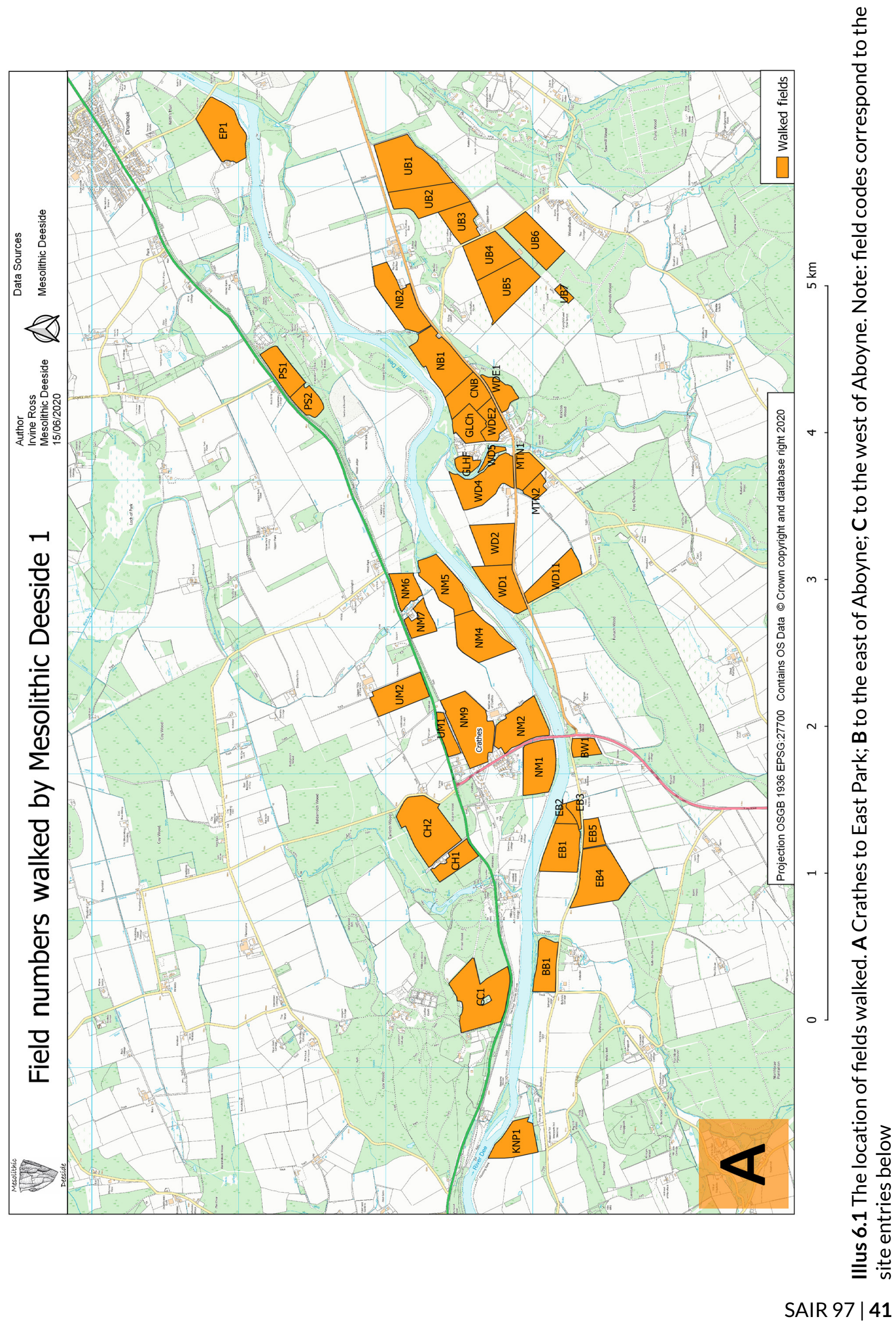




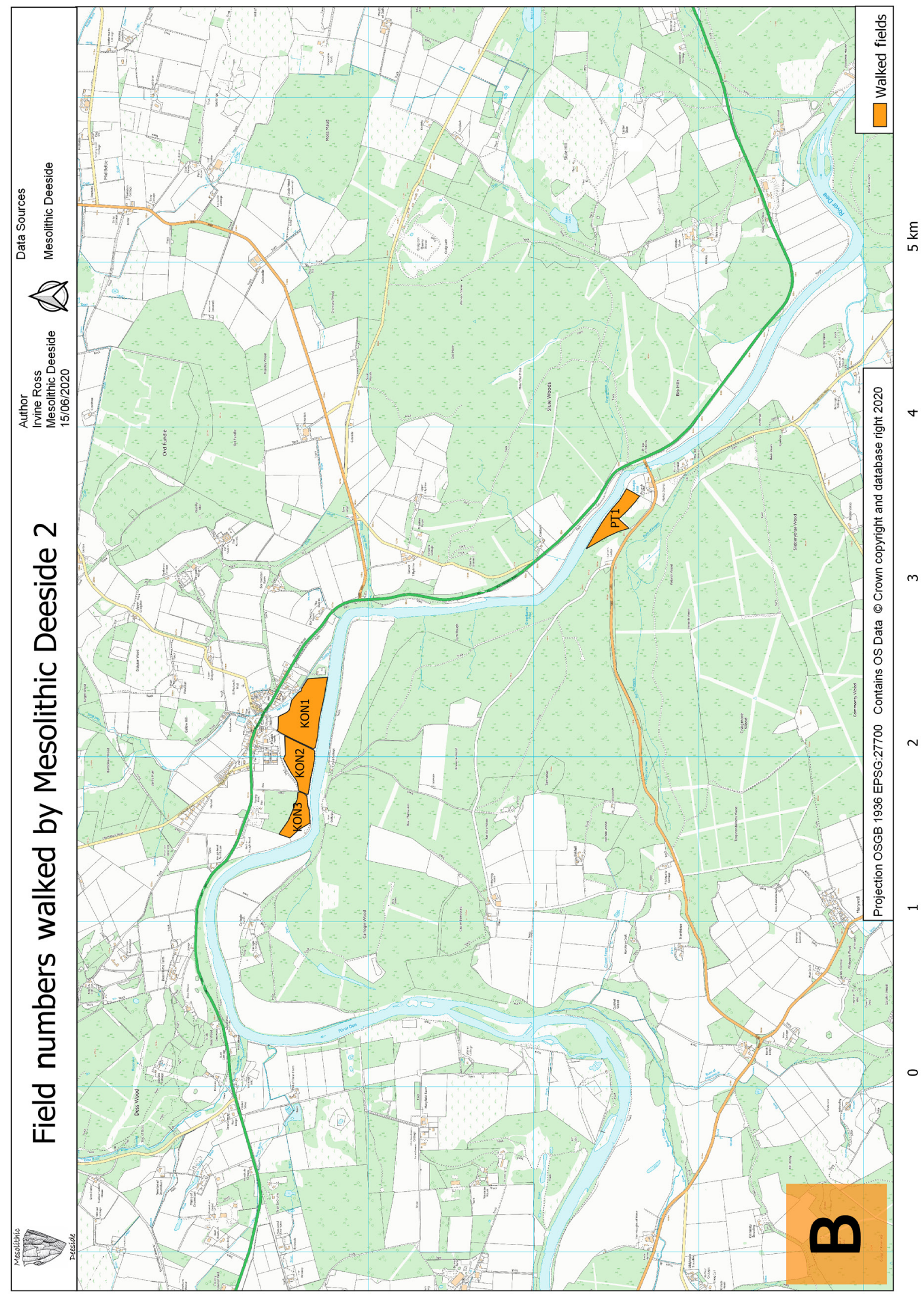




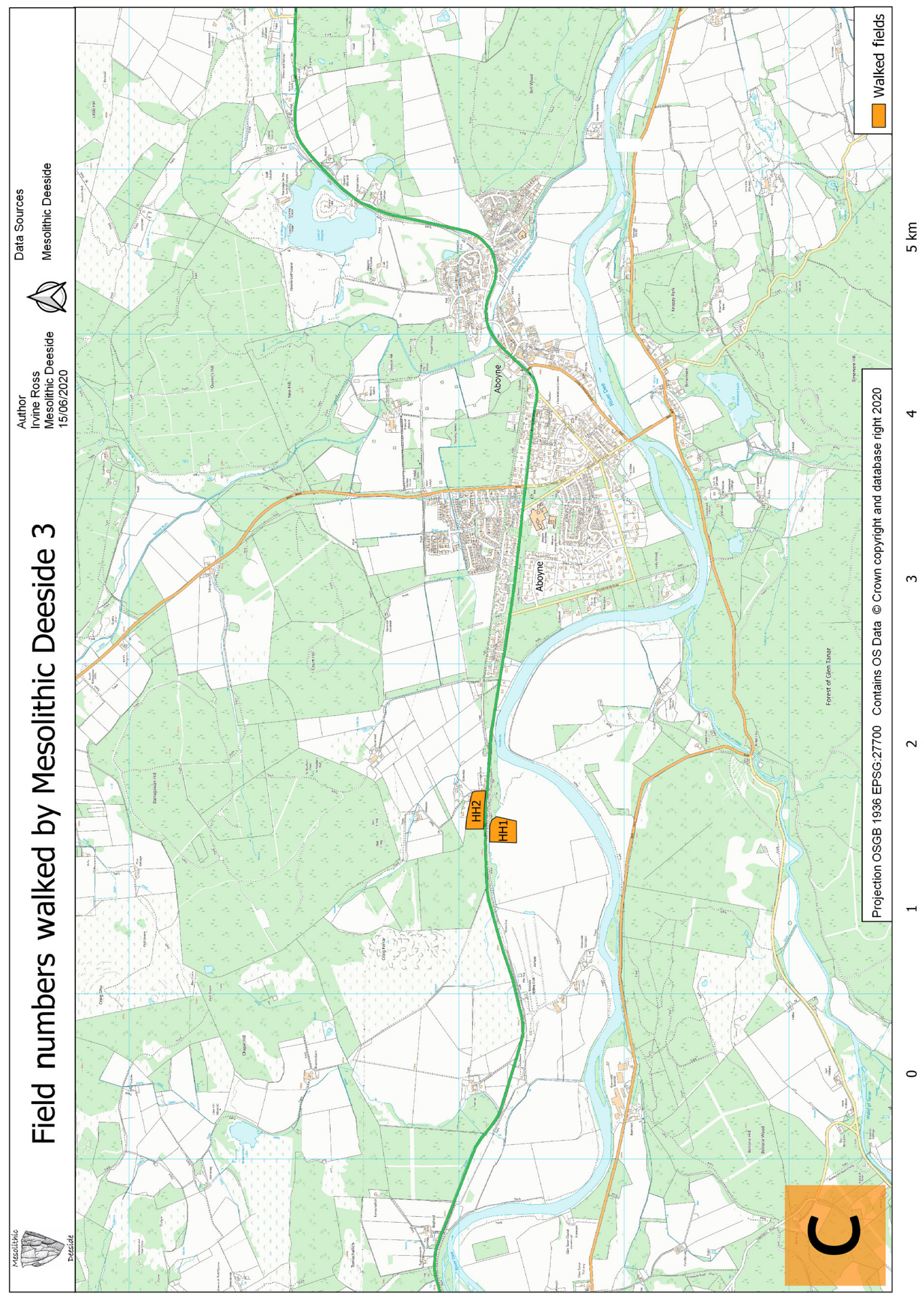




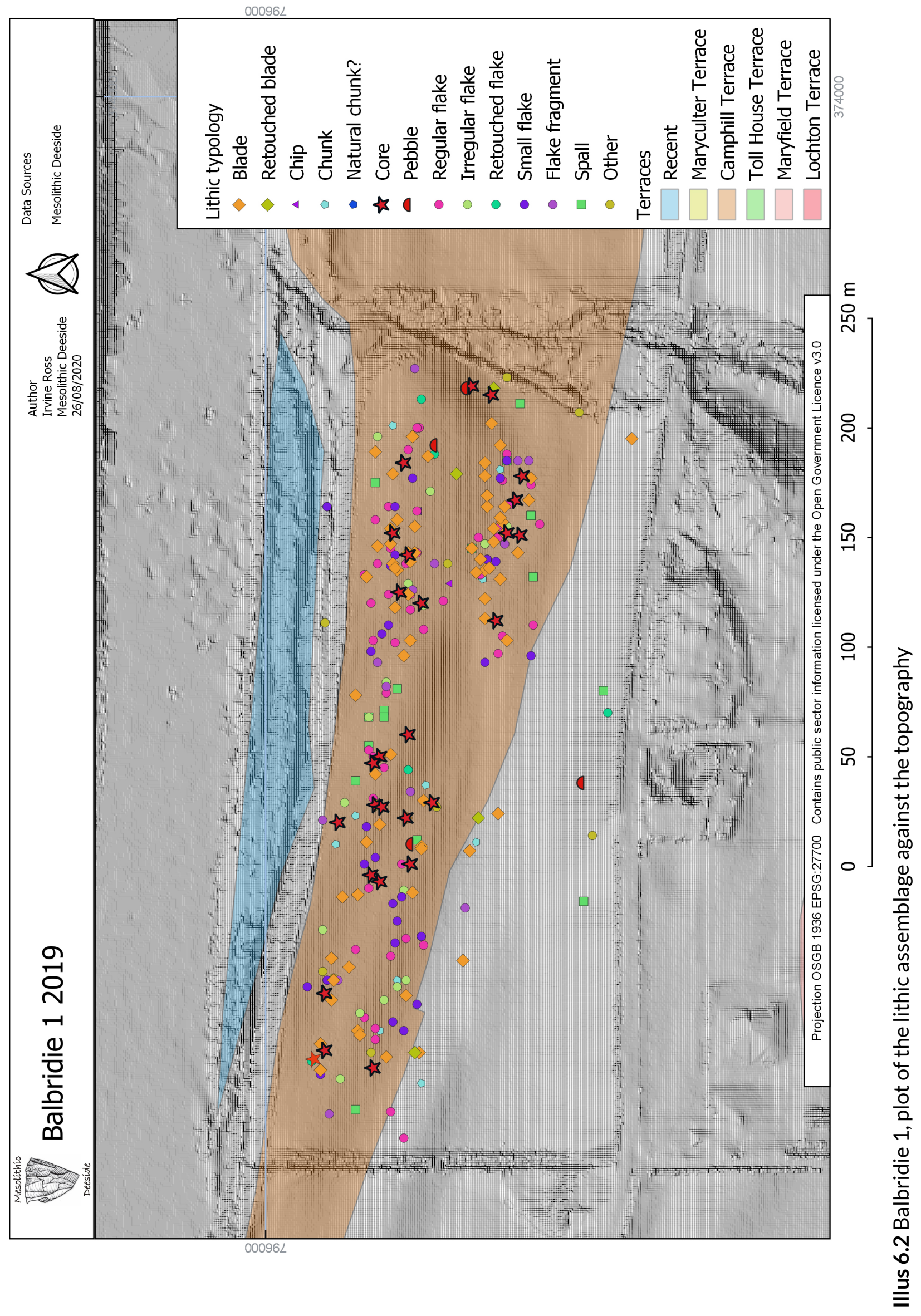




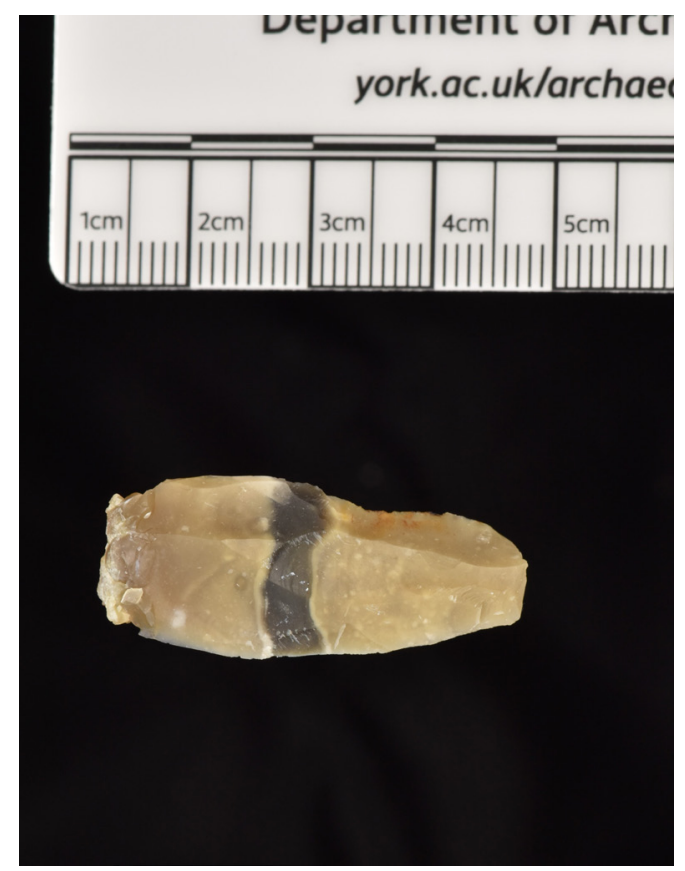

Illus 6.3 Blade from Balbridie 1
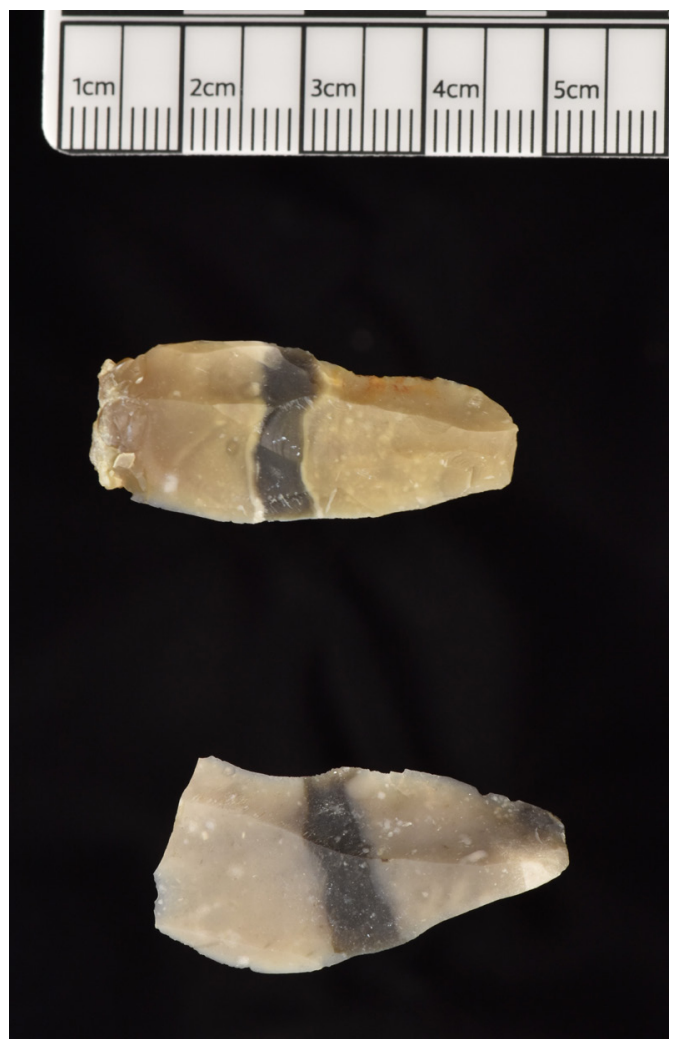

Illus 6.5 Blades, top Balbridie 1, bottom Star Carr

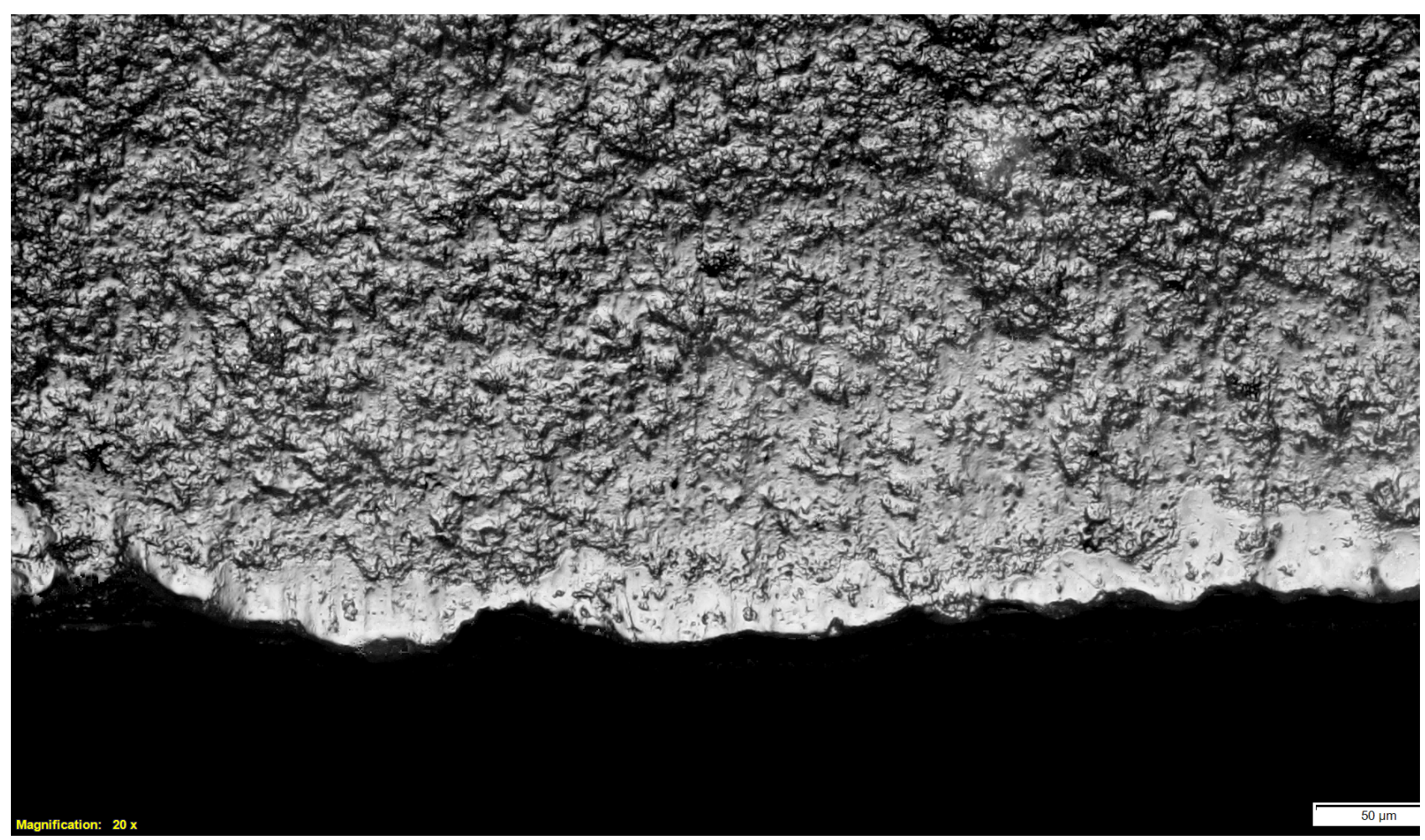

Illus 6.4 Polish on the right side of the ventral face of the blade, interpreted as used for whittling soft wood or vegetal material 
Table 6.1 Lithics from Balbridie 1

\begin{tabular}{|c|c|c|}
\hline Balbridie (BB1) & Flint & Type \\
\hline \multirow[t]{7}{*}{ Core } & 31 & Single-platform 13 \\
\hline & & Right-angled 2 \\
\hline & & Opposed-platform 1 \\
\hline & & Multi-platform 4 \\
\hline & & Core fragment 6 \\
\hline & & Bipolar 2 \\
\hline & & Flaked pebble 3 \\
\hline \multirow[t]{5}{*}{ Retouched tools } & 11 & Knife form 4 \\
\hline & & Scraper 3 \\
\hline & & Obliquely blunted blade 2 \\
\hline & & Microlith 1 \\
\hline & & Leaf point 1 \\
\hline Flakes & 116 & \\
\hline Blades & 83 & \\
\hline Chunks & 21 & \\
\hline Small flakes & 43 & \\
\hline Spalls & 16 & \\
\hline Pebbles & 0 & \\
\hline Total & 321 & \\
\hline Calcined (burnt) & 28 & \\
\hline Burnt/frost shatter & 9 & \\
\hline Other & 5 & \\
\hline
\end{tabular}

Agate: blade and flake

Blue quartzite: blade 1 , chunks 2 


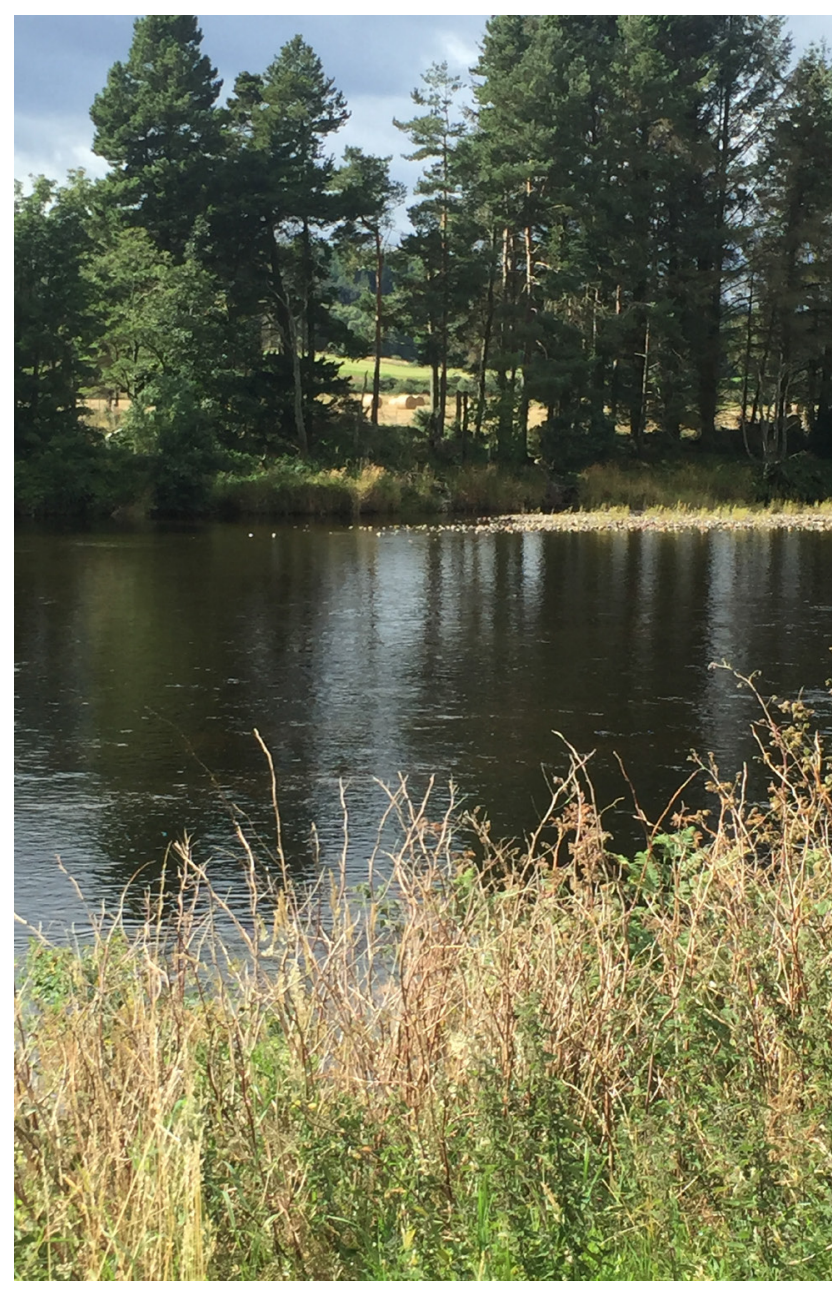

Illus 6.6 Balbridie East lies behind the trees, viewed from the north bank of the river

\subsection{Brigton West 1 (BW1)}

NGR: NO 7523595730

2.15 hectares, $<2$ pieces per hectare

Walked 16 April 2018, dry, field recently ploughed, not well weathered, heavy walking, 1 walker, $6-7 \mathrm{~m}$ transects

Aberdeenshire Historic Environment Record: NO79NW0130

Brigton West lies on the south bank of the river, to the west of Durris Bridge. The field does not sit on a specific terrace. It is in glacial till, sloping steeply down to the Dee. It was walked for prospection purposes and three flaked lithics were recovered (Table 6.5). To the east, immediately on the other side of Durris Bridge, lies the field of Brigton Farm which was walked by Kenney, and from which nine flints were recovered (Kenney 1993).

\subsection{Cairnballoch (CNB)}

NGR: NO 7754296587

5.17 hectares, 23 pieces per hectare

Existing records from the field: an enclosure; cropmark

Canmore: NO79NE 37

Aberdeenshire Historic Environment Record: NO79NE0048; NO79NE0052

Cairnballoch (Illus 6.8) lies to the west of, and adjacent to, Nether Balfour (section 6.11). The southern part of the field is on a large fragment of the Lochton Terrace surface at around $45 \mathrm{~m}$ $\mathrm{OD}$, but the northern part lies on steep ground in the Lochton Sand and Gravel Formation sloping down to the river. A total of 41 flaked lithics were recovered (Table 6.6), comprising a flake-dominated assemblage that includes a leaf point, two scrapers and a strike-a-light. There are distinct similarities between the lithic assemblages from the fields of Cairnballoch and Nether Balfour, both of which derive mainly from activity in the Neolithic and Bronze Age.

\subsection{Candieshill (CH1)}

NGR: NO 7434696692

c $60 \mathrm{~m}$ OD

3.75 hectares, $0-10$ pieces per hectare

Walked 5 February 2017, 12-15 walkers, 2m transects

Existing records: cropmark

Aberdeenshire Historic Environment Record: NO79NW0024; NO79NW0120; NO79NW0131

The fields at Candieshill sit back from the river on the northern bank, on an uneven, kettled, surface of the Lochton Terrace. A total of 26 lithics were collected, spread across the surface of the field. This field is located between the scatters at Crathes and the site at Warren Field.

A small assemblage of 26 pieces of worked flint was recovered (Illus 6.9; Table 6.7). This included three blades and four retouched pieces, as well as two cores: a multi-platform core and a bipolar core. Many of the pieces suggest Late Neolithic flint working, including both of the cores, though all of the retouched pieces were knife forms and possibly indicative of activity in the earlier Neolithic. 


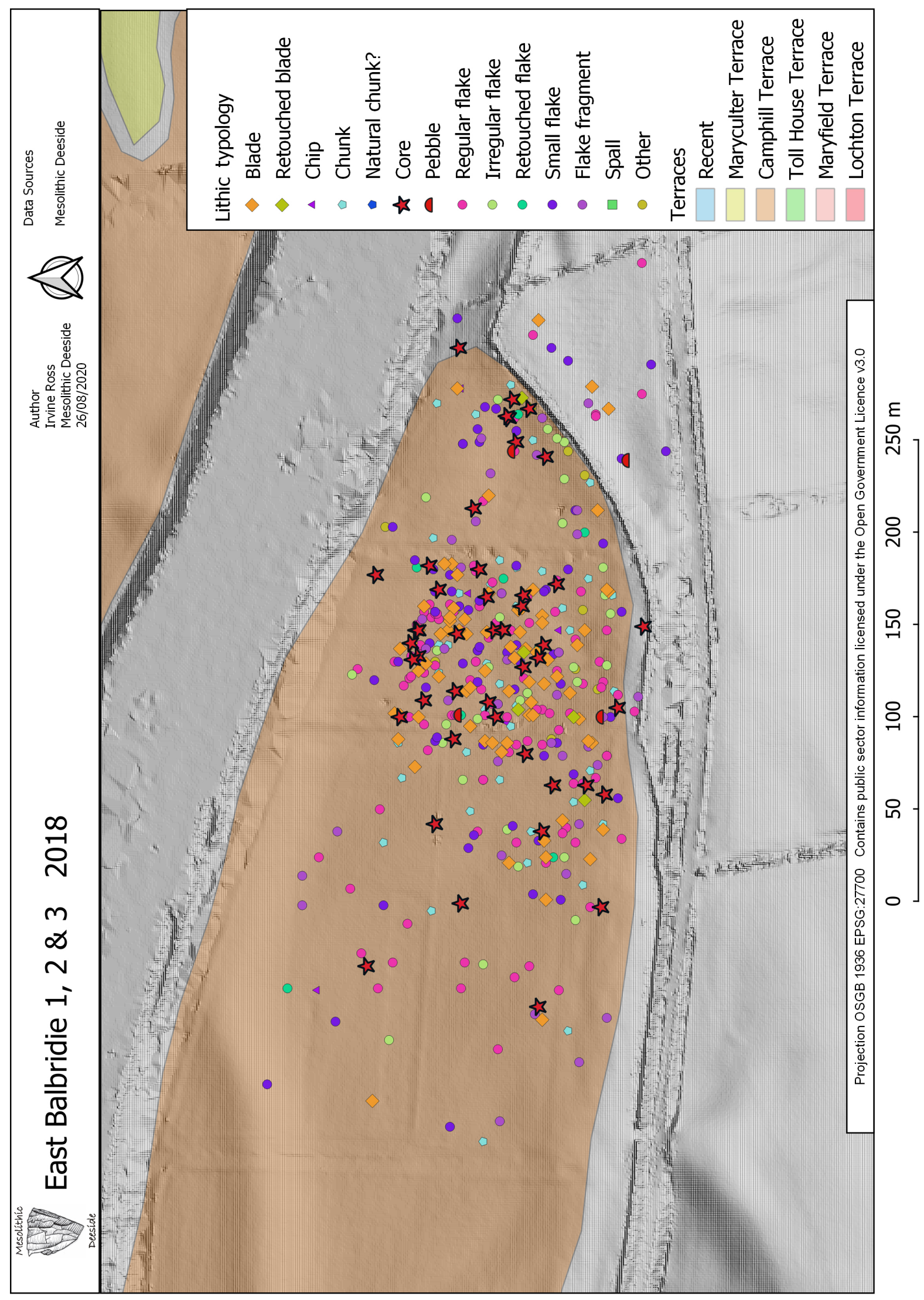

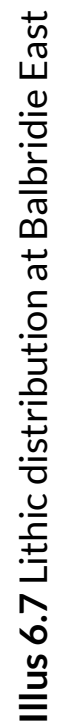


Table 6.2 Lithics from East Balbridie 1

\begin{tabular}{lcl} 
East Balbridie 1 (EB1) & Flint & Type \\
Core & 36 & Single-platform 20 \\
& & Multi-platform 2 \\
& Opposed-platform 1 \\
& Flaked chunk 3 \\
& Bipolar 2 \\
& Core fragment 6 \\
& Flaked pebble 2 \\
\hline Retouched tools & Awl 1 \\
& Bifacial 1 \\
& Edge retouched 1 \\
& Scraper 7 \\
& Knife form 1 \\
& Notched 1 \\
& Obliquely blunted blade 1 \\
& Serrated blade 1
\end{tabular}

\begin{tabular}{lr}
\hline Flakes & 186 \\
\hline Blades & 83 \\
\hline Chunks & 45 \\
\hline Small flakes & 67 \\
\hline Spalls & 0 \\
\hline Pebbles & 2 \\
\hline Total & 432 \\
\hline Calcined (burnt) & 11 \\
Burnt/frost shatter & 7 \\
\hline
\end{tabular}

Other

Quartz: bipolar core, chunks 3, flakes 9

Rhyolite: pebble

Black fine-grained stone 
Table 6.3 Lithics from East Balbridie 2

\begin{tabular}{lcl} 
East Balbridie 2 (EB2) & Flint & $\begin{array}{l}\text { Type } \\
\text { Core }\end{array}$ \\
& 7 & $\begin{array}{l}\text { Single-platform 1 } \\
\text { Multi-platform 4 } \\
\text { Right-angled 1 } \\
\text { Core fragment 1 }\end{array}$ \\
\hline Retouched tools & 5 & $\begin{array}{l}\text { Edge retouched 2 } \\
\text { Scraper 1 } \\
\end{array}$ \\
& & $\begin{array}{l}\text { Obliquely blunted blade 1 } \\
\text { Spokeshave 1 }\end{array}$ \\
\hline Flakes & 22 & \\
\hline Blades & 3 & \\
\hline Chunks & 6 & \\
\hline Small flakes & 10 & \\
\hline Spalls & 0 & \\
\hline Pebbles & 1 & \\
\hline Total & 54 & \\
\hline Calcined (burnt) & 1 & \\
Burnt/frost shatter & 0 & \\
\hline Other & Mudstone? chunk & \\
\hline
\end{tabular}

Table 6.4 Lithics from East Balbridie 3

\begin{tabular}{lcl} 
East Balbridie 3 (EB3) & Flint & Type \\
Core & 1 & Core fragment 1 \\
\hline Retouched tools & 0 & \\
\hline Flakes & 8 & \\
\hline Blades & 3 & \\
\hline Chunks & 0 & \\
\hline Small flakes & 5 & \\
\hline Spalls & 0 & \\
\hline Pebbles & 1 & \\
\hline Total & 18 & \\
\hline Calcined (burnt) & 0 & \\
Burnt/frost shatter & 0 &
\end{tabular}


Table 6.5 Lithics from Brigton West

\begin{tabular}{lc} 
Brigton West (BW) & Flint \\
Core & 0 \\
\hline Retouched tools & 0 \\
\hline Flakes & 0 \\
\hline Blades & 1 \\
\hline Chunks & 1 \\
\hline Small flakes & 1 \\
\hline Spalls & 0 \\
\hline Pebbles & 0 \\
\hline Total & 3 \\
\hline Calcined (burnt) & 0 \\
Burnt/frost shatter & 0 \\
\hline Other & 0
\end{tabular}

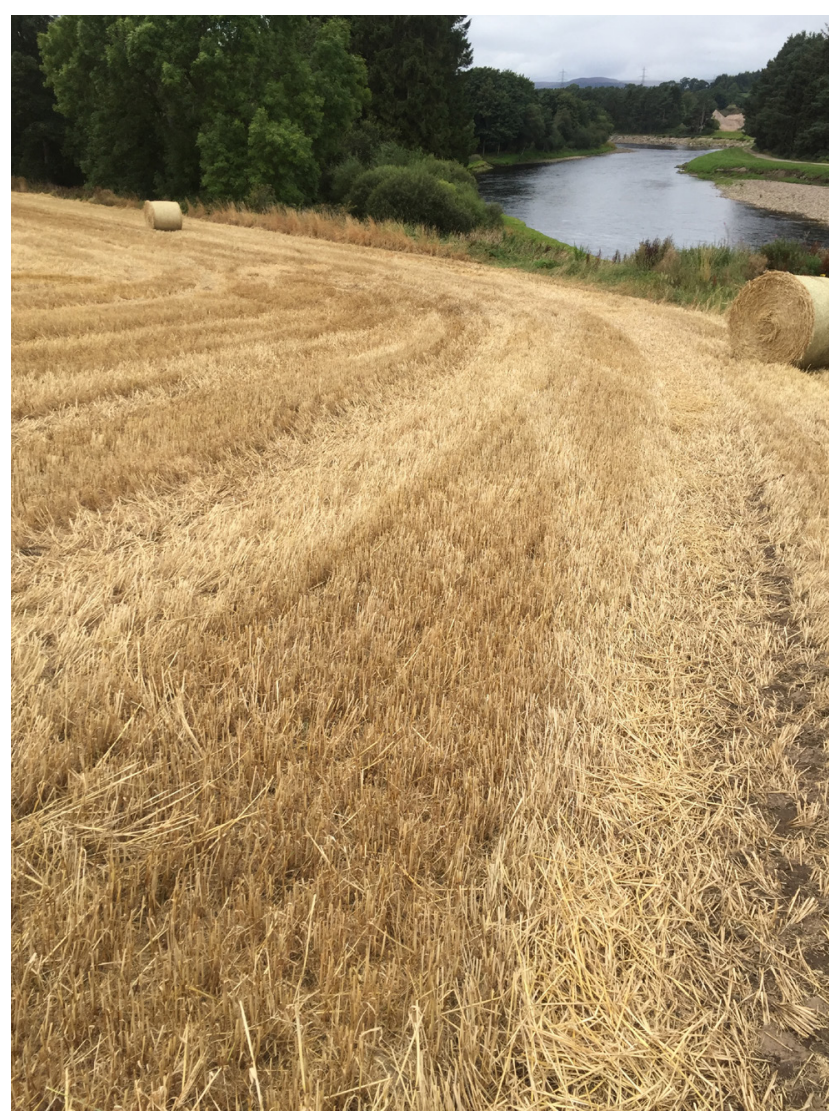

Illus 6.8 The field at Cairnballoch from the east, sloping down to the River Dee

Table 6.6 Lithics from Cairnballoch

\begin{tabular}{lcl} 
Cairnballoch (CNB) & Flint & $\begin{array}{l}\text { Type } \\
\text { Opposed-platform 1 } \\
\text { Core fragment 1 }\end{array}$ \\
\hline Retouched tools & 2 & $\begin{array}{l}\text { Leaf point 1 } \\
\text { Edge retouched 1 } \\
\text { Scraper 2 } \\
\text { Knife 1 } \\
\text { Strike-a-light 1 }\end{array}$ \\
& 6 & \\
\hline Flakes & 13 & \\
\hline Blades & 1 & \\
\hline Chunks & 11 & \\
\hline Small flakes & 6 & \\
\hline Spalls & 0 & \\
\hline Pebbles & 2 & \\
\hline Total & 41 & \\
\hline Calcined (burnt) & 0 & \\
Burnt/frost shatter & 0 & \\
\hline Other & 0 &
\end{tabular}




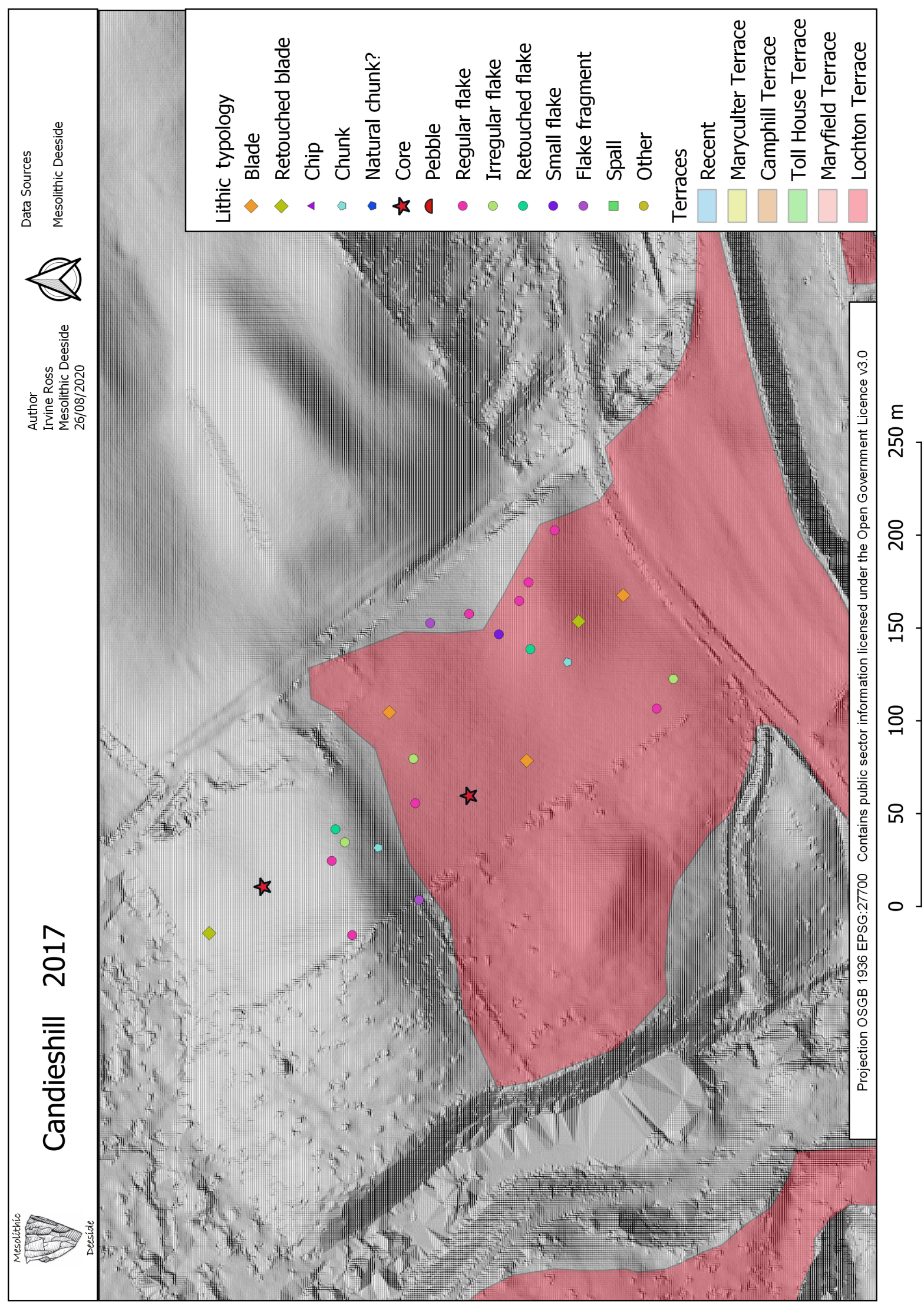

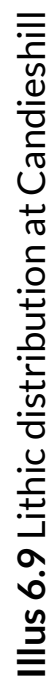


Table 6.7 Lithics from Candieshill

\begin{tabular}{lrl} 
Candieshill $(\mathrm{CH} 1)$ & Flint & $\begin{array}{l}\text { Type } \\
\text { Core }\end{array}$ \\
\hline Retouched tools & 2 & $\begin{array}{l}\text { Multi-platform 1 } \\
\text { Bipolar 1 }\end{array}$ \\
\hline Flakes & 43 & Knife form 4 \\
\hline Blades & 3 & \\
\hline Chunks & 3 & \\
\hline Small flakes & 1 & \\
\hline Spalls & 0 & \\
\hline Pebbles & 0 & \\
\hline Total & 26 & \\
\hline Calcined (burnt) & 2 & \\
Burnt/frost shatter & 0 & \\
\hline Other & 0 &
\end{tabular}

\subsection{Crathes Castle (CC1)}

NGR: NO 7356996565

\section{c $50 \mathrm{~m} \mathrm{OD}$}

12.49 hectares, $0-10$ pieces per hectare

Walked 19 February 2017, 12-15 walkers, 2m transects

Existing records from the field: a number of historic sites: aviary; ice-house; burial ground; ha-ha

Canmore: NO79NW 135; NO79NW 142; NO79NW 8.09; NO79NW 128

Aberdeenshire Historic Environment Record: NO79NW0052; NO79NW0117; NO79NW0121

Crathes Castle field sits above the river. The highest part of the field lies on the Lochton Terrace, the surface of which is kettled and crossed by shallow palaeochannels. The original terrace surface has not survived here. A small stretch of Maryfield Terrace has been identified in the south of the field. Twentyseven lithics were recovered (Table 6.8), spread thinly across the field (Illus 6.10). They are not indicative of a period.

\subsection{East Park 1 (EP1)}

NGR: NO 7945598296

9.61 hectares, $>300$ pieces per hectare

Walked in 2016 (2 walkers), 5 March 2017, 26
January, 9 and 17 February 2019 (12-15 walkers). Mixed wind and rain, $2 \mathrm{~m}$ transects

Aberdeenshire Historic Environment Record: NO79NE0023; NO79NE0126

The large field at East Park (Illus 6.11) is geomorphologically complex and the full details of this are set out below in the discussion of test pitting at the site (see 7.2 'East Park, Drumoak'). While the north-west of the field, around East Park Farm, is not a terrace surface, the northern half of the field does preserve an undulating fragment of the Maryfield Terrace, lying at around $35 \mathrm{~m}$ $\mathrm{OD}$, from the western end of which a steep slope falls south towards the river. At its base a narrow surface around $30 \mathrm{~m} \mathrm{OD}$, and $6 \mathrm{~m}$ above the present surface of the Dee, correlates altitudinally with the Camphill Terrace, though OSL analyses of relative deposition profiles (see 7.2.1 'Geomorphology and pIRSL/pOSL analyses') suggest that it formed at a different time. In the east a different landscape has been preserved. A large undulating surface some 1.5-2m below the Maryfield Terrace may represent a fortuitously preserved late-stage deposit of the terrace. Adjacent slopes are gentle, but later fluvial incision has created a steep slope that falls to the river, interrupted in places by a narrow surface which is poorly developed except near Park Bridge. 


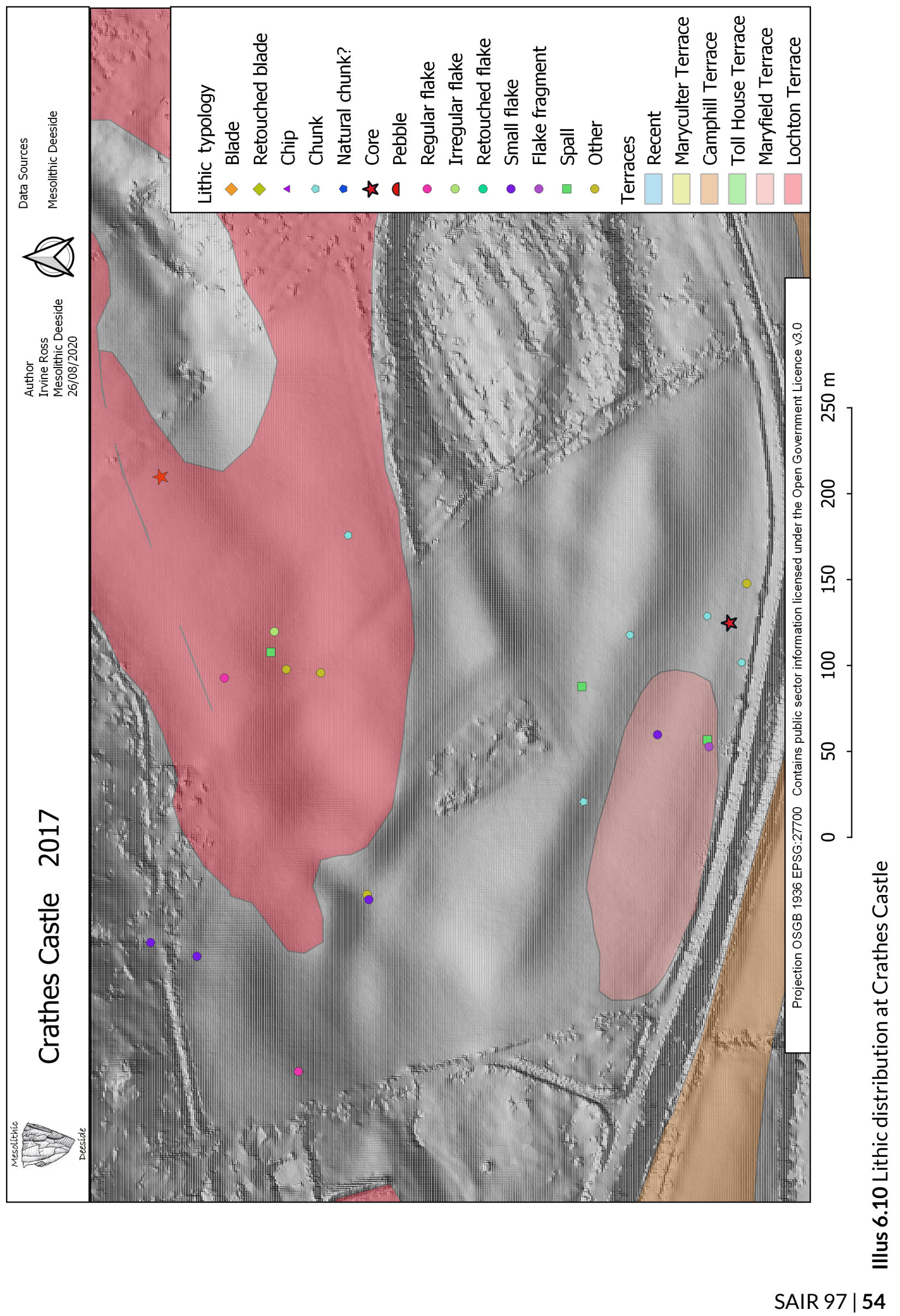


Table 6.8 Lithics from Crathes Castle

\begin{tabular}{lcl} 
Crathes Castle & Flint & $\begin{array}{l}\text { Type } \\
\text { Core }\end{array}$ \\
\hline Retouched tools & 2 & $\begin{array}{l}\text { Single-platform 1 } \\
\text { Core fragment 1 }\end{array}$ \\
\hline Flakes & 0 & \\
\hline Blades & 5 & \\
\hline Chunks & 5 & \\
\hline Small flakes & 6 & \\
\hline Spalls & 5 & \\
\hline Pebbles & 3 & \\
\hline Total & 0 & \\
\hline Calcined (burnt) & 26 & \\
Burnt/frost shatter & 8 & \\
\hline
\end{tabular}

Other Rhyolite chunk

This surface is not correlated with the Camphill or Maryculter Terraces.

The field has been investigated archaeologically several times, and there has also been a collection of lithics along the footpath between the field and the river (Tables $7.8 \& 7.9$ ). In addition, it was test pitted in 2018. Prior to the test pitting, only the lowest portion of the field, alongside the river, had been walked. This resulted in the recording of 648 lithics, the provenance of which is included in the wider discussion below (see 7.2.4 'East Park: lithic distribution'). The total number of lithics from East

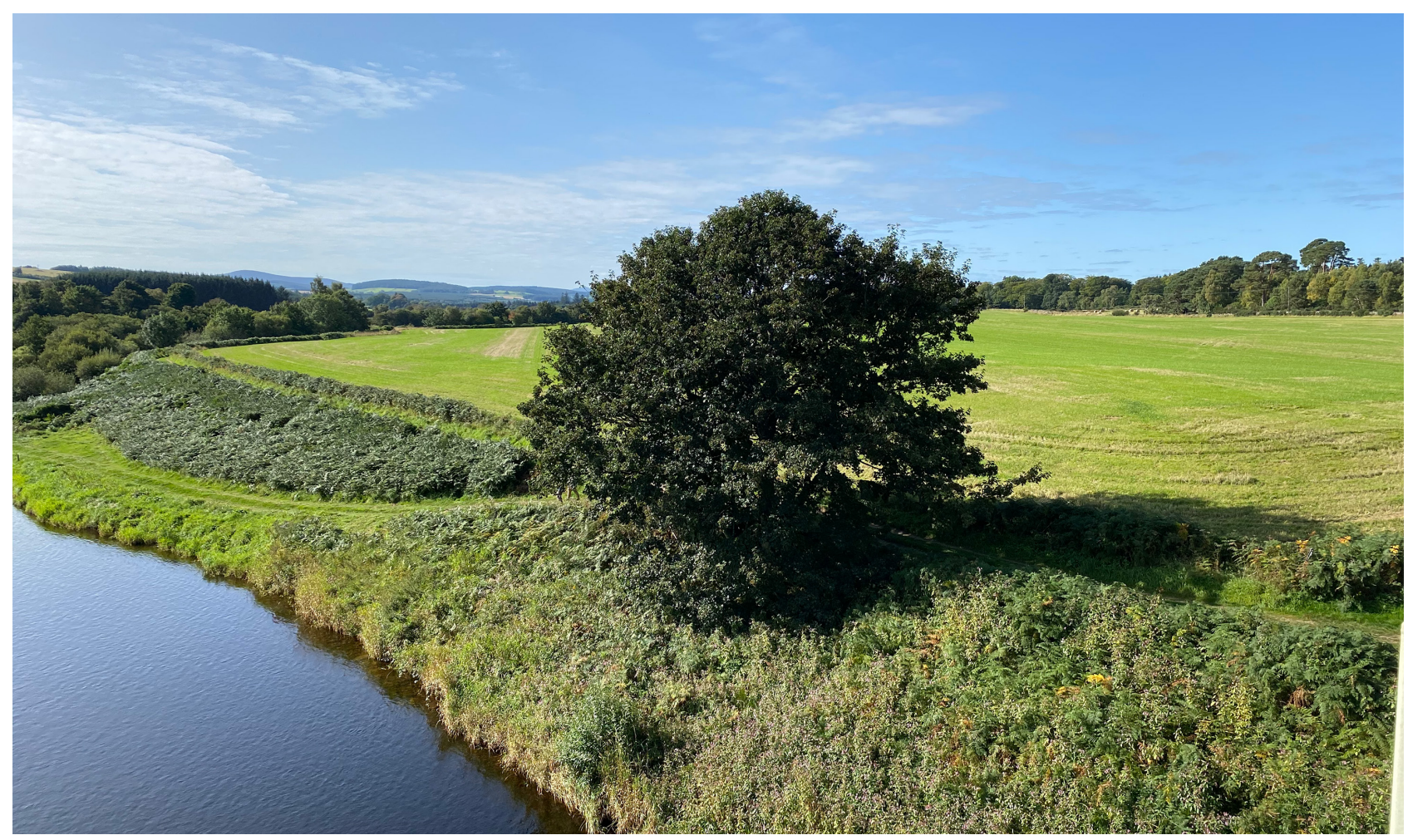

Illus 6.11 East Park from the east 


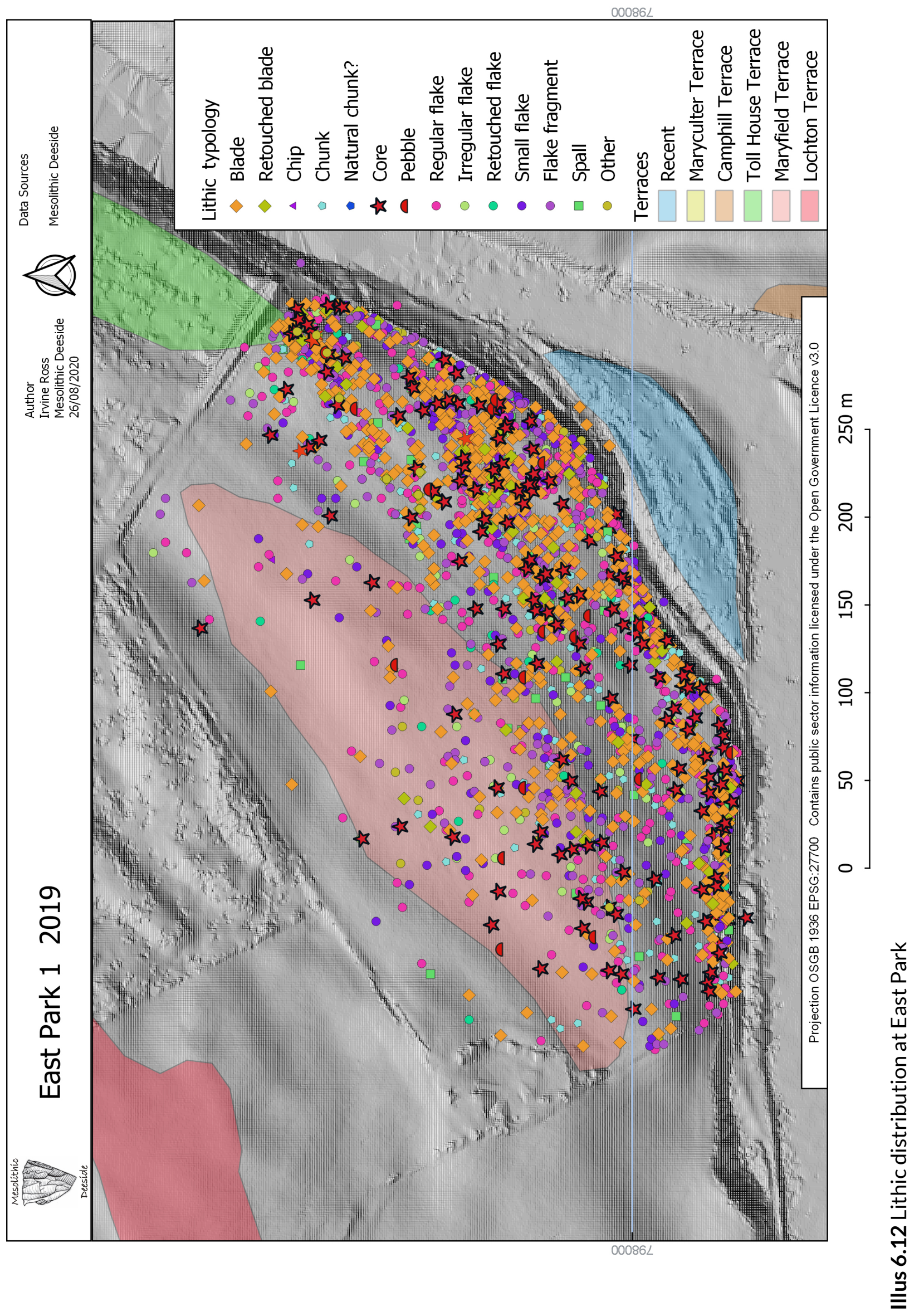


Park (including test pitting, further fieldwalking, and an assemblage of 260 pieces collected by students from the University of Aberdeen on a fieldwalking exercise in 2018) numbers 3,948 pieces. The assemblages have clearly accumulated over a considerable period of time and include artefacts typical of Late Upper Palaeolithic, Mesolithic and Neolithic activity. The lithics seem to concentrate along the southern and eastern (lower) edge of the Maryfield Terrace and on the slopes falling to the river (Illus 6.12), and the significance of the geomorphological complexity for interpreting this spatial patterning is left to the longer discussion below (7.2.4 'East Park: lithic distribution'). Overall, the assemblage contains a high number of cores and blades, both retouched and unretouched. The lithic assemblages from the different episodes of investigation have been combined and are discussed in the test pit report, below (7.2.2 'Lithics').

\subsection{Heughhead $1 \& 2(\mathrm{HH} 1 ; \mathrm{HH} 2)$}

HH1, NGR: NO 50019 98814; 150m; 2.3 hectares; $<1$ piece per hectare

HH2, NGR: NO 50221 98920; 2.21 hectares; $>100$ pieces per hectare

Walked 23 and 24 March 2019, windy but sunny with heavy rain on the second day

Aberdeenshire Historic Environment Record: NO59NW0117; NO49NE0159

These two fields sit on a till surface above two lower river terraces, towards the present river. The highest of these terraces is considered to have formed in the Younger Dryas Stadial because of the superb examples of braided river palaeochannels that cross it, a morphology absent on Holocene terrace surfaces (Maizels 1985; Maizels \& Aitken 1991). However, it has not been dated. The British Geological Survey (1996: Merritt et al 2003) maps this terrace as a lateral equivalent of the Camphill Terrace, which itself is likely to be earlier than the Younger Dryas (as dated by the occurrence of Late Upper Palaeolithic artefacts). The lower terrace surface at Heughhead is probably the Maryculter Terrace. A total of 239 lithics were recorded in the higher of the two fields, concentrated towards the lower slopes of the field (Illus 6.13), possibly due to the impact of colluviation. Only two pieces were found on the lower surface. This site was also test pitted (see 7.3 'Heughhead'; discussion of the lithics is included there).

\subsection{Kincardine O'Neil 1, 2 \& 3 (KON1; KON2; KON3)}

KON1, NGR: NO $5947199374 ; c 98 m$ OD; 7.62 hectares; $20-30$ pieces per hectare

KON2, NGR: NO 59166 99567; 4.05 hectares; 10-20 pieces per hectare

KON3, NGR: NO 58782 99418; 2.51 hectares; 10-20 pieces per hectare

97-99m OD

Walked 21 and 31 January 2018, overcast and damp, cold with a hard frost, and 2 March 2019, windy but bright, between 18 and 24 volunteers, $2 \mathrm{~m}$ transects broadening to $4 \mathrm{~m}$ in 2019

Existing records: a polished axehead, medieval hospital, old parish church

Canmore: NO59NE 63; NO59NE 6; NO59NE 1 Aberdeenshire Historic Environment Record: NO59NE0019; NO59NE0023; NO59NE0024; NO59NE0039; NO59NE0058; NO59NE0005; NO59NE0132; NO59NE0133; NO59NE0134

Three contiguous fields along the left bank, some $3 \mathrm{~m}$ to $4 \mathrm{~m}$ above the east-flowing River Dee, were walked in 2018 and 2019. They are flat terrace surfaces, mapped on BGS Geoindex as alluvium (ie the Maryculter Terrace equivalent). This is likely to be in error because GE imagery shows Fields KON1 and KON2 to have ploughed-out north/south trending medial bars that probably comprised parts of a braided river system. The one civil engineering borehole (British Geological survey reference: NO59NE10; http://scans.bgs.ac.uk/sobi scans/boreholes/15941296/images/16229044.html) records coarse gravel to the surface. The terrace is probably the Camphill Terrace equivalent. The lithics are scattered fairly uniformly across the fields, with a slightly higher concentration to the east in KON1. A total of 278 pieces was found (Tables 6.9, $6.10 \& 6.11)$, distributed across the surface of the field (Illus 6.14). In general, there are few retouched pieces, and the assemblages are dominated by flakes, though KON1 also has a high proportion of blades to flakes. Though chronologically specific pieces are lacking, the assemblages suggest activity predominantly in the Neolithic with, perhaps, some Mesolithic elements. 


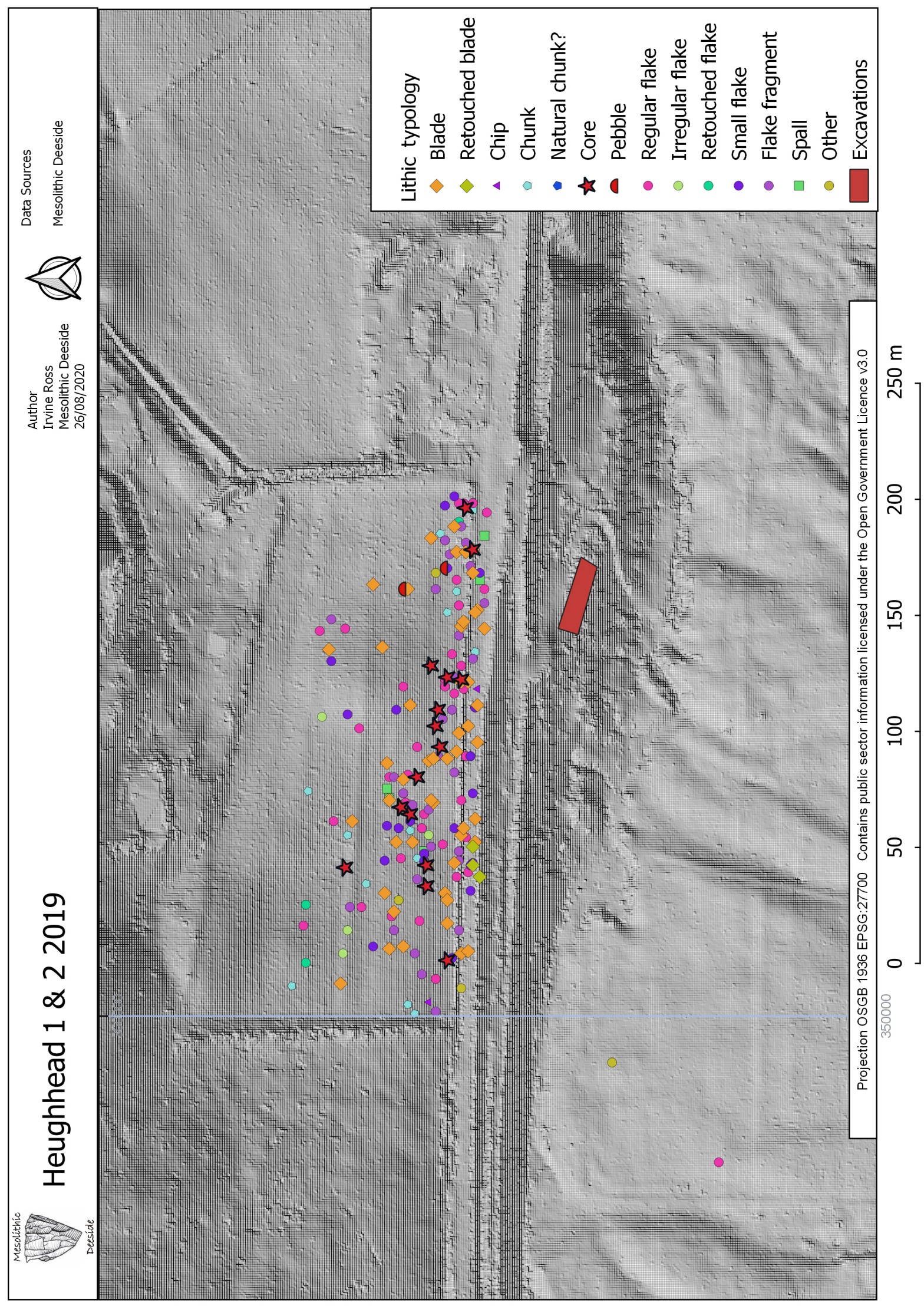

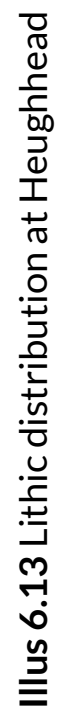




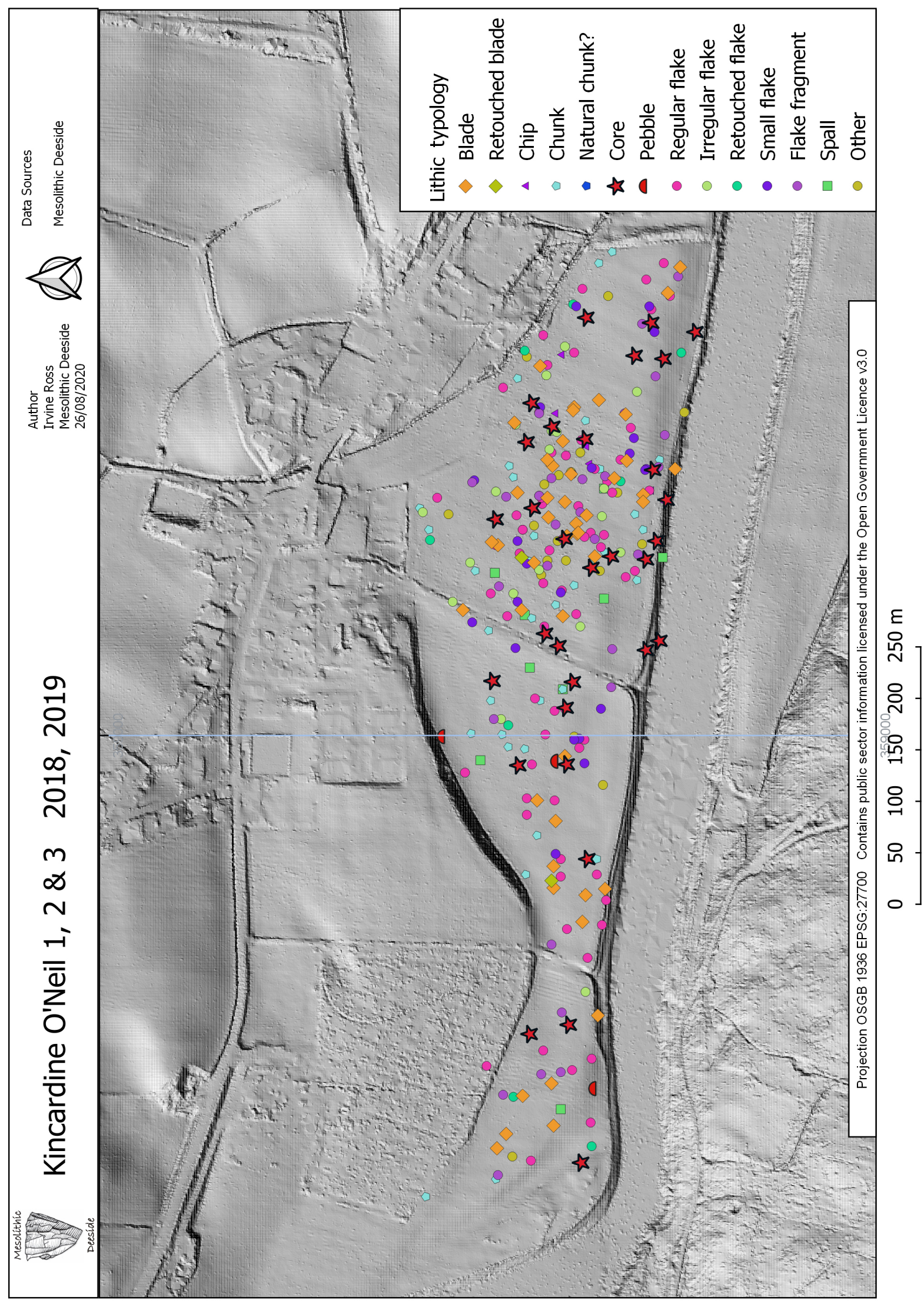

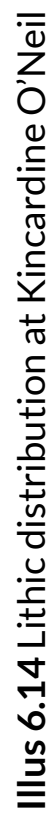


Table 6.9 Lithics from Kincardine O'Neil 1

\begin{tabular}{lcl} 
Kincardine O'Neil 1 (KON1) & Flint & $\begin{array}{l}\text { Type } \\
\text { Core }\end{array}$ \\
& 22 & $\begin{array}{l}\text { Single-platform 8 } \\
\text { Multi-platform 2 } \\
\text { Opposed-platform 2 } \\
\text { Bipolar 1 } \\
\text { Core fragment 9 }\end{array}$ \\
& & \\
\hline Retouched tools & 0 & \\
\hline Flakes & 86 & \\
\hline Blades & 32 & \\
\hline Chunks & 36 & \\
\hline Small flakes & 14 & \\
\hline Spalls & 0 & \\
\hline Pebbles & 0 & \\
\hline Total & 190 & \\
\hline Calcined (burnt) & 12 & \\
Burnt/frost shatter & 3 & \\
\hline Other & 0 &
\end{tabular}

Table 6.10 Lithics from Kincardine O'Neil 2

\begin{tabular}{lcl} 
Kincardine O'Neil 2 (KON2) & Flint & $\begin{array}{l}\text { Type } \\
\text { Core }\end{array}$ \\
& 6 & $\begin{array}{l}\text { Single-platform 2 } \\
\text { Core fragment 3 } \\
\text { Bipolar 1 }\end{array}$ \\
\hline Retouched tools & 22 & Scraper 2 \\
\hline Flakes & 5 & \\
\hline Blades & 11 & \\
\hline Chunks & 7 & \\
\hline Small flakes & 3 & \\
\hline Spalls & 1 & \\
\hline Pebbles & 57 & \\
\hline Total & 9 \\
Calcined (burnt) & 1 \\
Burnt/frost shatter & Agate: knife form \\
\hline Other & Chalcedony: \\
& pebble 1, blade 1
\end{tabular}


Table 6.11 Lithics from Kincardine O'Neil 3

\begin{tabular}{lcl} 
Kincardine O'Neil 3 (KON3) & Flint & $\begin{array}{l}\text { Type } \\
\text { Core }\end{array}$ \\
& 3 & $\begin{array}{l}\text { Single-platform 1 } \\
\text { Core fragment 1 } \\
\text { Bipolar 1 }\end{array}$ \\
\hline Retouched tools & 2 & Scraper 2 \\
\hline Flakes & 12 & \\
\hline Blades & 6 & \\
\hline Chunks & 2 & \\
\hline Small flakes & 1 & \\
\hline Spalls & 1 & \\
\hline Pebbles & 1 & \\
\hline Total & 28 & \\
\hline Calcined (burnt) & 6 & \\
Burnt/frost shatter & 0 & \\
\hline Other & 0 &
\end{tabular}

\subsection{Knappach (KNP1)}

NGR: NO 7262996142

c $43 \mathrm{~m}$ OD

5.84 hectares, 6 pieces per hectare

Walked 15 March 2017, dry sunny, well weathered, 12-15 walkers

Existing records: Dr Grieve recorded a flint scatter at Birkwood to the west, NO 71802 96195; a cist burial containing a late $3 \mathrm{rd}$-millennium $\mathrm{BC}$ Beaker and other artefacts including fragments of a copper awl, is also recorded as having been ploughed up, and excavated, on the south bank of this field (Lelong 2019).

Canmore: NO79NW 12; NO79NW 79

Aberdeenshire Historic Environment Record: NO79NW0009; NO79NW0081; NO79NW0122

Knappach lies to the east of Balbridie, to the south of the river, on a narrow surface of the Camphill Terrace (Illus 6.15). The end rigs and western section of the field were walked for prospection purposes. Thirty-two lithics were recovered (Illus 6.16; Table 6.12), suggesting activity in the Late Neolithic, as well as other periods. There were three cores, and three retouched pieces.

\subsection{Mosside 1 (MS1)}

NGR: NO 8025999116

$35-37 \mathrm{~m}$ OD

3.89 hectares, 2 pieces per hectare

NB: A pipeline runs through this field

Walked 19 April 2018, dry, sunny, well weathered, 1 walker

Aberdeenshire Historic Environment Record: NO89NW0100

The field at Mosside lies to the north of the river, about a kilometre to the east of East Park. Most of the field is in a kettled surface of the Lochton Terrace. The western end rig was walked for prospection purposes and eight pieces of flint were recovered including a single blade and the fragment of a core (Table 6.13). There was also a single quartz flake. The assemblage was not diagnostic to a particular period.

\subsection{Nether Balfour (NB1)}

NGR: NO 7789396829

44-45m OD

9.81 hectares, 29.66 pieces per hectare (only 33\% of the field surface was walked)

Walked in winter 2001, 17 January 2002, January 2003, 24 January 2003, 26 January 2003, 7, 14 and 


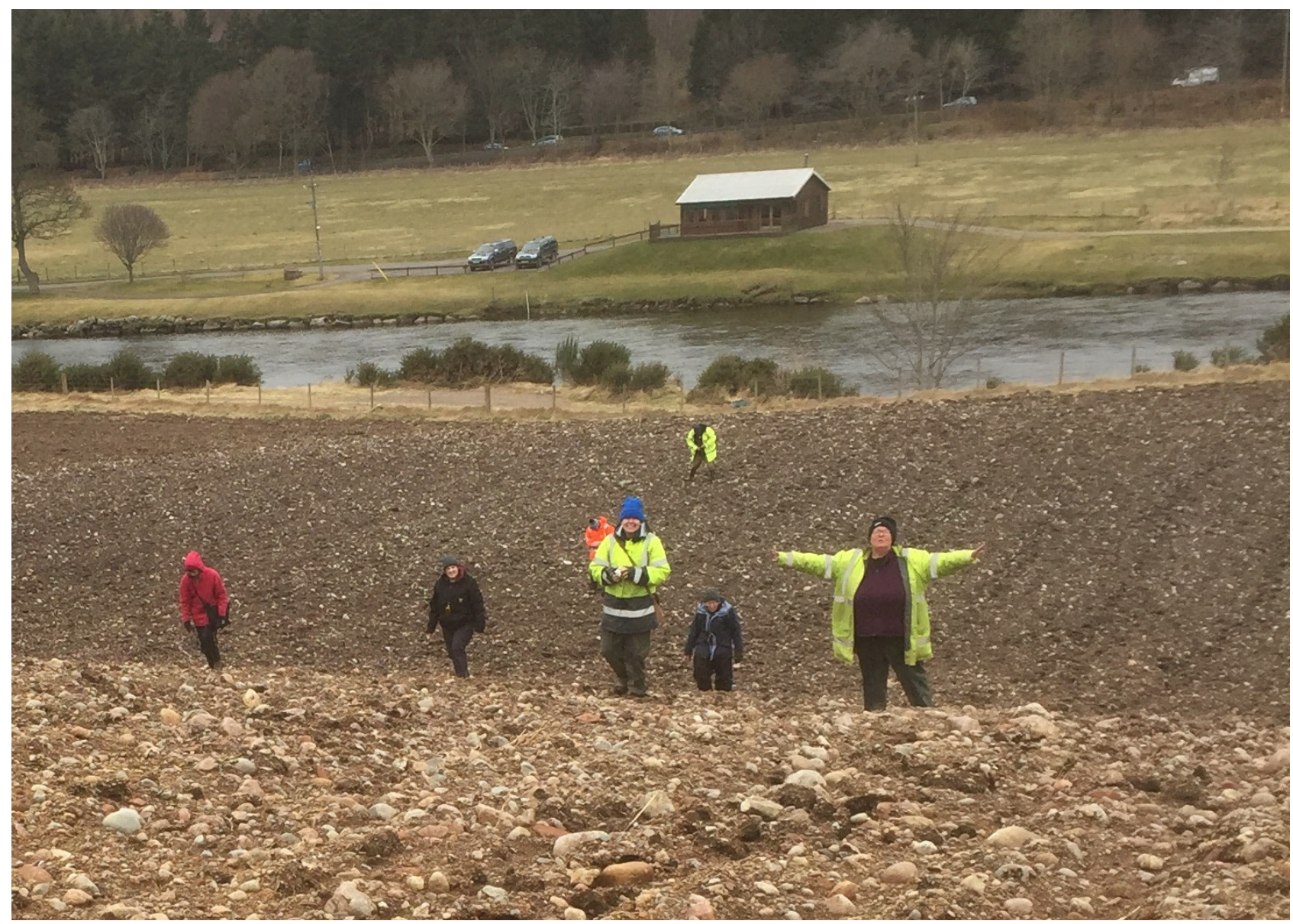

Illus 6.15 Fieldwalking at Knappach on the south bank of the River Dee

Table 6.12 Lithics from Knappach

\begin{tabular}{lll}
$\begin{array}{l}\text { Knappach (KNP1) } \\
\text { Core }\end{array}$ & Flint & $\begin{array}{l}\text { Type } \\
\text { Retouched tools }\end{array}$ \\
\hline Flakes & 3 & $\begin{array}{l}\text { End scraper 2 } \\
\text { Edge retouched 1 }\end{array}$ \\
\hline Blades & 11 & \\
\hline Chunks & 3 & \\
\hline Small flakes & 2 & \\
\hline Spalls & 4 & \\
\hline Pebbles & 4 & \\
\hline Total & 2 & \\
\hline Calcined (burnt) & 32 & \\
Burnt/frost shatter & 4 & \\
\hline Other & 4 &
\end{tabular}




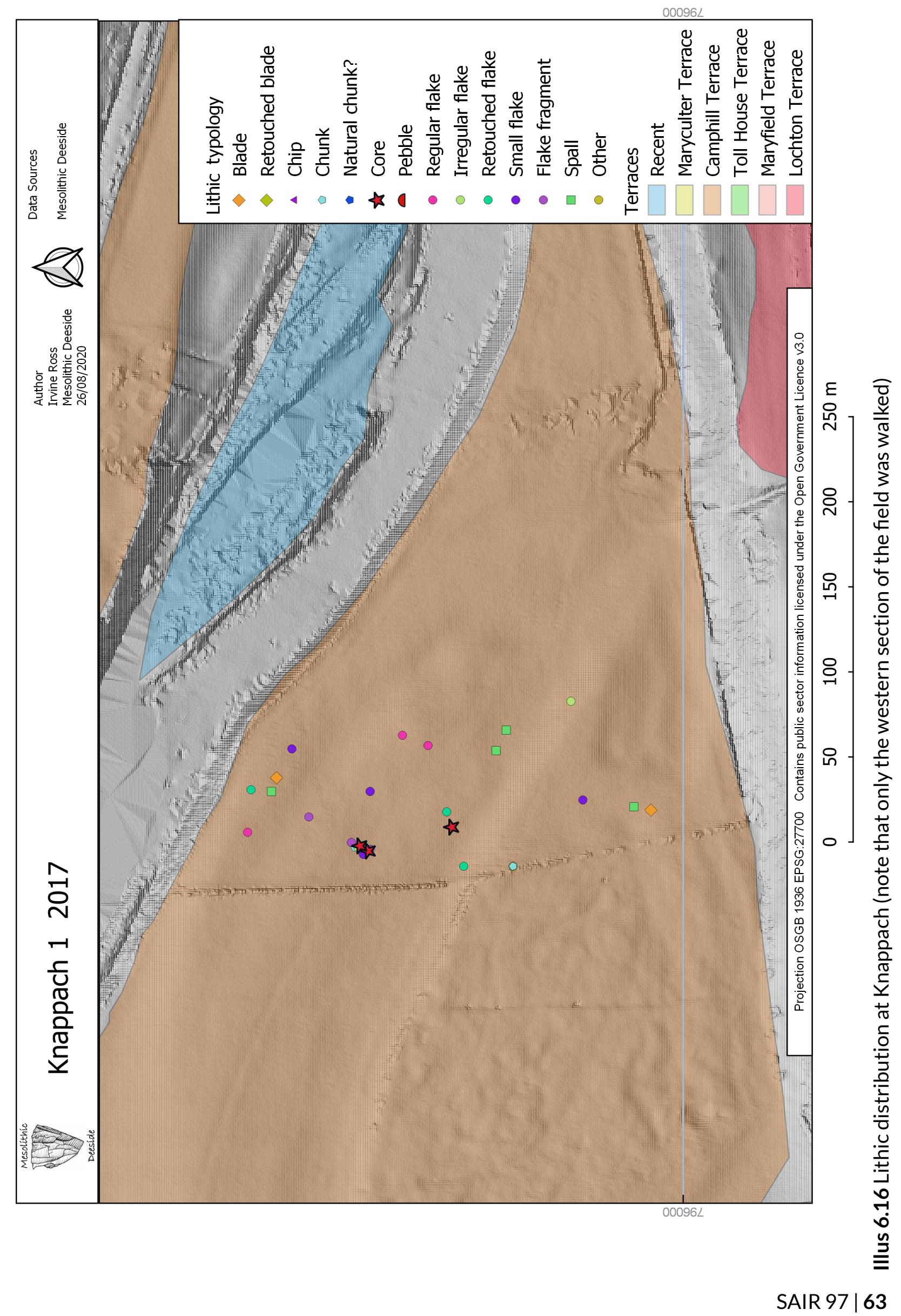


Table 6.13 Lithics from Mosside

\begin{tabular}{lcl} 
Mosside 1 Drumoak & Flint & Type \\
Core & 1 & Core fragment 1 \\
\hline Retouched tools & 0 & \\
\hline Flakes & 1 & \\
\hline Blades & 1 & \\
\hline Chunks & 1 & \\
\hline Small flakes & 4 & \\
\hline Spalls & 0 & \\
\hline Pebbles & 0 & \\
\hline Total & 8 & 0 \\
\hline Calcined (burnt) & 0 \\
\hline Burnt/frost shatter & Quartz: flake
\end{tabular}

22 February 2003, 1 and 16 March 2003. Ploughed and well weathered, 1 walker, $6-7 \mathrm{~m}$ transects

Existing records: a motte, Castle Hill, Durris, is recorded adjacent to the field

Canmore: NO79NE 1

Aberdeenshire Historic Environment Record: NO79NE0001

Nether Balfour lies on the south side of the river (Illus 6.17). As at adjacent Cairnballoch (see 6.3 'Cairnballoch (CNB)'), the southern part of this field occupies a large fragment of the Lochton Terrace, but the northern part is on steep ground in the Lochton Sand and Gravel Formation, sloping to the river. It was walked on several occasions, and a total of 97 flaked lithics was found (though not plotted by dGPS); in addition, there was a bead of black glass. The adjoining fields at Nether Balfour and Cairnballoch yielded very similar assemblages which are likely to form part of a single spread. The assemblages are flake dominated (Table 6.14), and this, together with the retouched pieces, suggests activity from the Neolithic into the Bronze Age.

\subsection{Nethermills Farm}

\subsubsection{Nethermills Farm 1 and 2 (NM1; NM2)}

NM1

NGR: NO 7517996056

7.43 hectares, 24 pieces per hectare

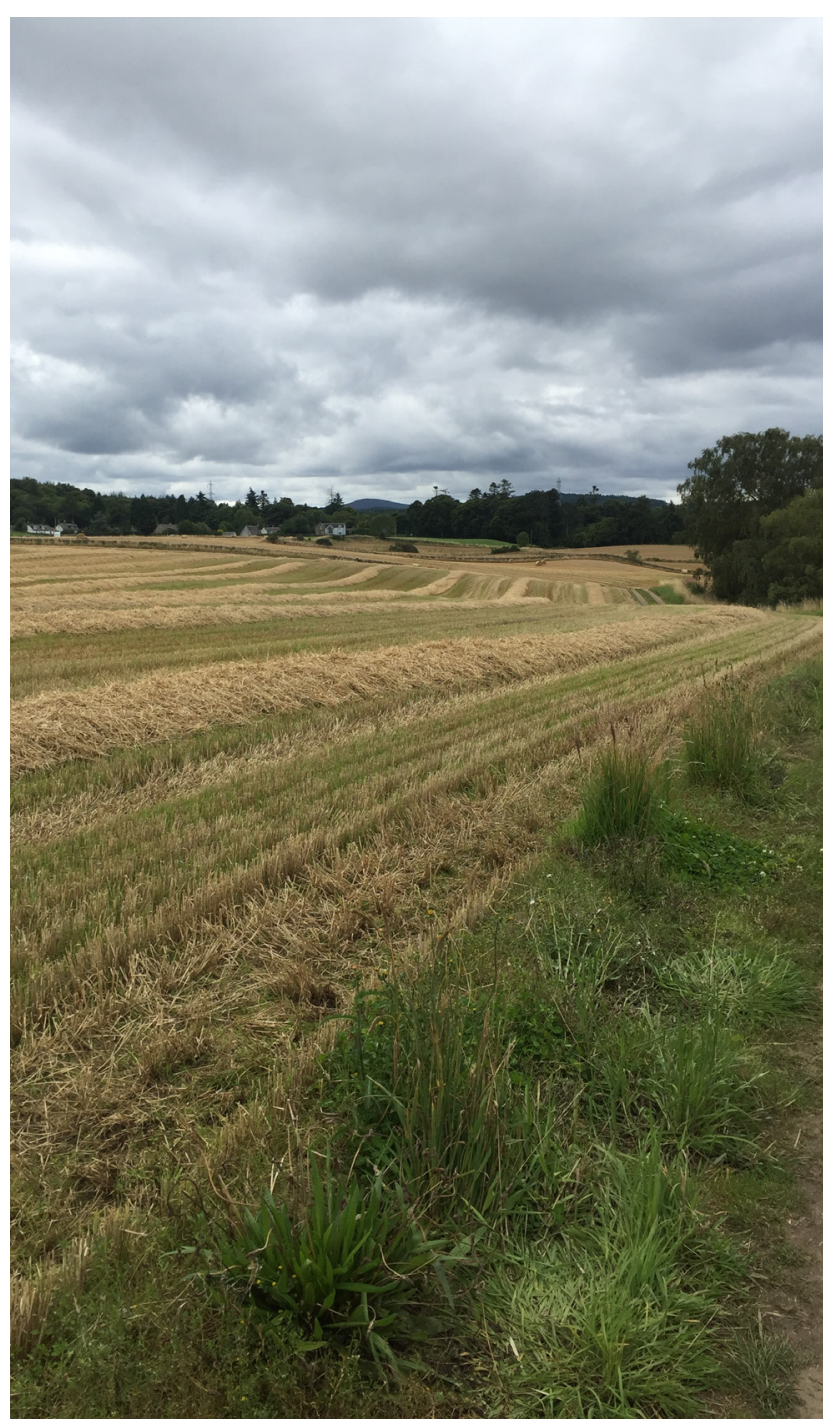

Illus 6.17 Nether Balfour: field view 
Table 6.14 Lithics from Nether Balfour

\begin{tabular}{|c|c|c|}
\hline Nether Balfour 1 & Flint & Type \\
\hline \multirow[t]{6}{*}{ Core } & 9 & Single-platform 1 \\
\hline & & Opposed-platform 1 \\
\hline & & Multi-platform 3 \\
\hline & & Bipolar 2 \\
\hline & & Core fragment 1 \\
\hline & & Flaked pebble 1 \\
\hline \multirow[t]{7}{*}{ Retouched tools } & 12 & Leaf point 1 \\
\hline & & Awl 1 \\
\hline & & Edge retouched 3 \\
\hline & & Scraper 4 \\
\hline & & Knife 1 \\
\hline & & Strike-a-light 1 \\
\hline & & Notched 1 \\
\hline Flakes & 26 & \\
\hline Blades & 6 & \\
\hline Chunks & 29 & \\
\hline Small flakes & 13 & \\
\hline Spalls & 2 & \\
\hline Pebbles & 2 & \\
\hline Total & 99 & \\
\hline Calcined (burnt) & 6 & \\
\hline Burnt/frost shatter & 4 & \\
\hline Other & of rhy & \\
\hline
\end{tabular}

Walked 25 January 2003 and August 2006, 1 walker Existing records: flint scatter, named Durris Bridge by Canmore, and Crathes Mains by the Aberdeenshire Historic Environment Record Canmore: NO79NE 24; NO79NE 94

Aberdeenshire Historic Environment Record: NO79NE0022

NM2

NGR: NO 7533196244

8.1 hectares, 67 pieces per hectare

Walked 5 January 2004, 25 October 2017, 18 and 24 February 2018

Existing records: flint scatter Canmore: NO79NE 23; NO79NE 29

Aberdeenshire Historic Environment Record: NO79NE0028; NO79NE0099
Field NM1 (Illus 6.18) is immediately downstream of Milton Cottage (field MC, previously walked by OFARS). The northern part of the field lies on the Camphill Terrace, reduced here to a width of $c 60 \mathrm{~m}$. It has east/west trending palaeochannels. The wider $(c 150 \mathrm{~m})$ southern part lies on the Maryculter Terrace. Channels on this terrace surface cut across the floodplain to the north-east. Field NM1 is Grieve's Site A (as recorded by Roger Daly in an unpublished transcript of Grieve's handwritten notes held by Aberdeen City Museums). Grieve associated the densest concentrations of lithics with small mounds of sand and gravel rising above the terrace surface. These have not been mapped but may be gravel bars. The most recent fieldwalking at Nethermills Farm 1 yielded 181 


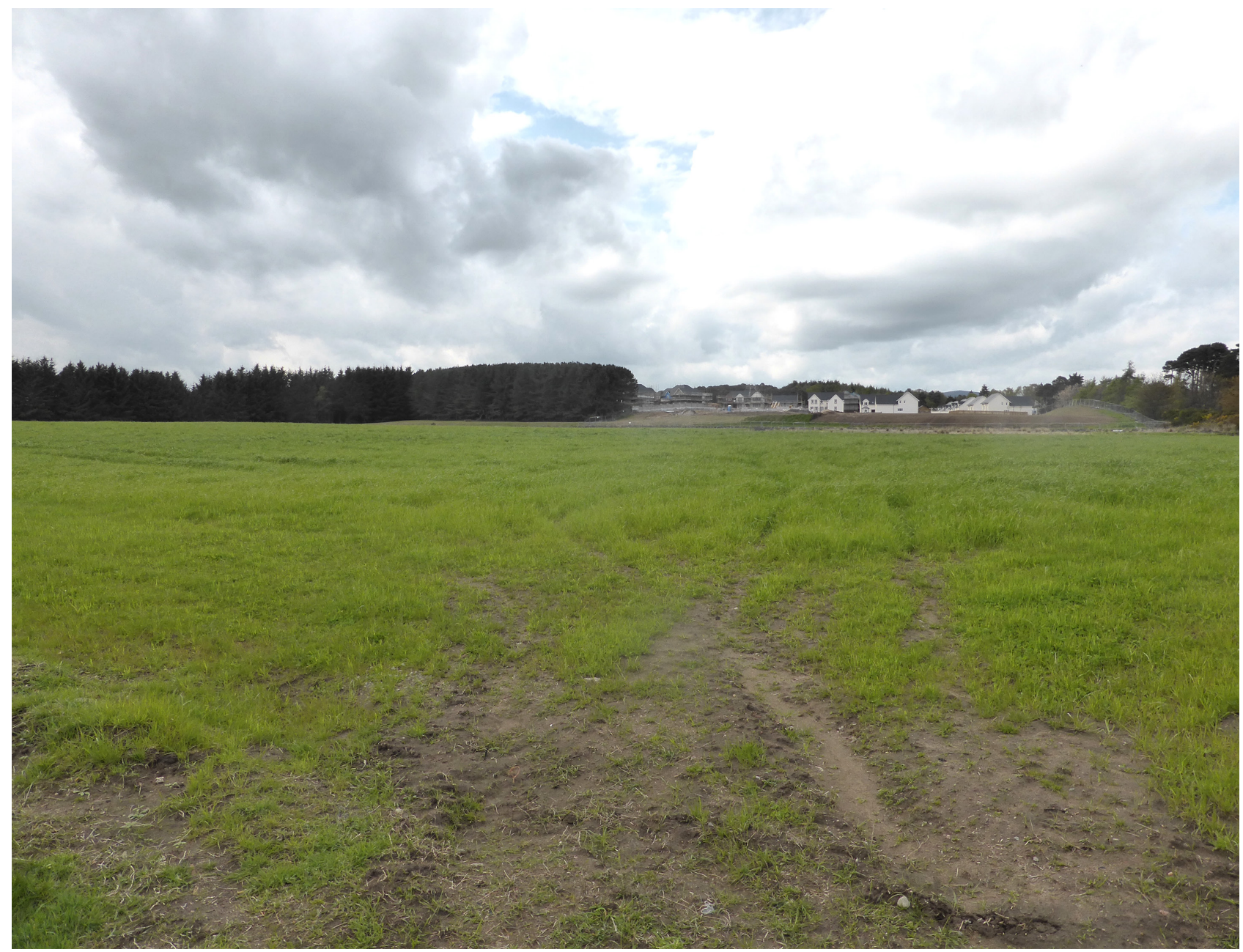

Illus 6.18 Nethermills Farm, NM1, from the south

lithics (Table 6.15), almost entirely confined to the Camphill Terrace (Illus 6.19), with a few scattered across the surface of the Maryculter Terrace surface.

On Nethermills Farm 2 (Illus 6.20), to the east of Durris Bridge, the spatial distribution of lithics on the surface of the ground reflects the river terrace stratigraphy. The field is $c 400 \mathrm{~m}$ long north to south and contains three terrace surfaces. Furthest north, Maryfield Terrace gravels at $c 42.5 \mathrm{~m}$ OD surround and partly erode a ridge of unmodified glacial debris. A break of slope falls to the Camphill Terrace at $37 \mathrm{~m}$ OD. A further break of slope falls to a thin spread of sand in the Maryculter Terrace at around $35.5 \mathrm{~m}$ OD, $2.5 \mathrm{~m}$ above the present surface of the Dee. Nethermills Farm 2 yielded 470 lithics (Table 6.16). Assuming that all parts of the field have been walked equally, the great majority of lithics in several campaigns of fieldwalking have been recovered in ploughed soil from the Camphill Terrace (Illus 6.21). Very few pieces have been recovered from the higher and older Maryfield Terrace. A few lithics have been retrieved from the steep slope separating the Camphill and Maryculter Terraces, and on the Maryculter Terrace, although colluvial processes probably associated with plough-disturbance may have been responsible for this lower spread.

\subsubsection{Nethermills Farm 3 \& 4 (NM3; NM4)}

\section{NM3}

NGR: NO 7575796362

$35 \mathrm{~m}$ OD

8.68 hectares, 2 pieces per hectare

Walked in May 2002, 1 walker

NM4

NGR: NO 7606996524

$35 \mathrm{~m}$ OD

8.54 hectares, $>300$ pieces per hectare 


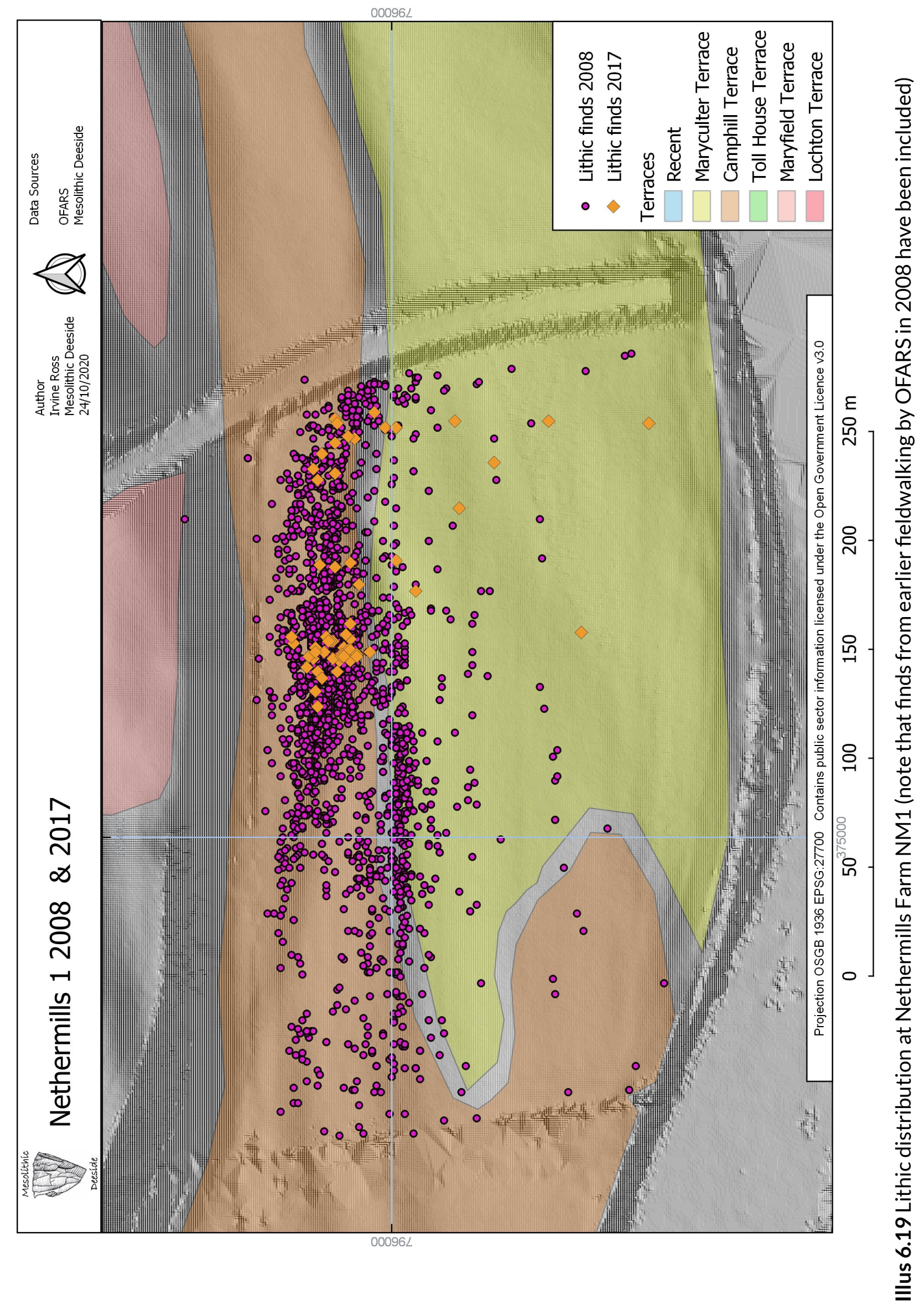




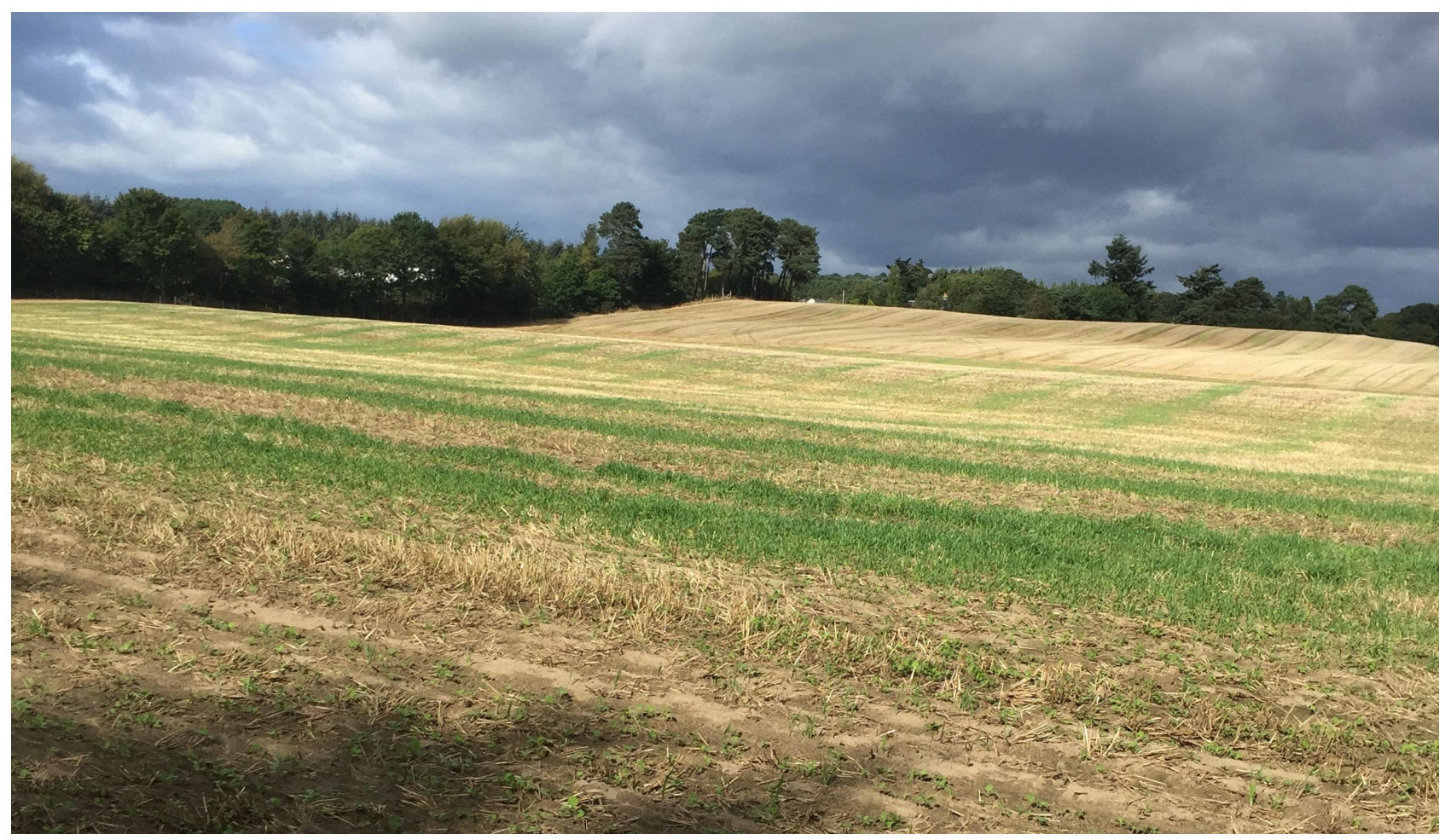

Illus 6.20 Nethermills Farm NM2, from the south-east. The Maryfield Terrace surface lies at the rear of the field, falling to the Camphill Terrace in the centre and down to the Maryculter Terrace in the foreground

Table 6.15 Lithics from Nethermills Farm 1

\begin{tabular}{lcl} 
NM1 & Flint & $\begin{array}{l}\text { Type } \\
\text { Core }\end{array}$ \\
& 11 & $\begin{array}{l}\text { Single-platform 7 } \\
\text { Core fragment 1 } \\
\text { Bipolar 1 } \\
\text { Flaked pebble 2 }\end{array}$ \\
\hline Retouched tools & 9 & $\begin{array}{l}\text { Knife 1 } \\
\text { Scraper 2 } \\
\text { Edge retouched 2 } \\
\text { Awl 2 } \\
\text { Strike-a-light 2 }\end{array}$ \\
& & \\
\hline Flakes & & \\
\hline Blades & 87 & \\
\hline Chunks & 43 & \\
\hline Small flakes & 10 & \\
\hline Spalls & 17 & \\
\hline Pebbles & 4 & \\
\hline Total & 0 & \\
\hline Calcined (burnt) & 181 & \\
Burnt/frost shatter & 21 & \\
\hline Other & 0 & \\
\hline
\end{tabular}




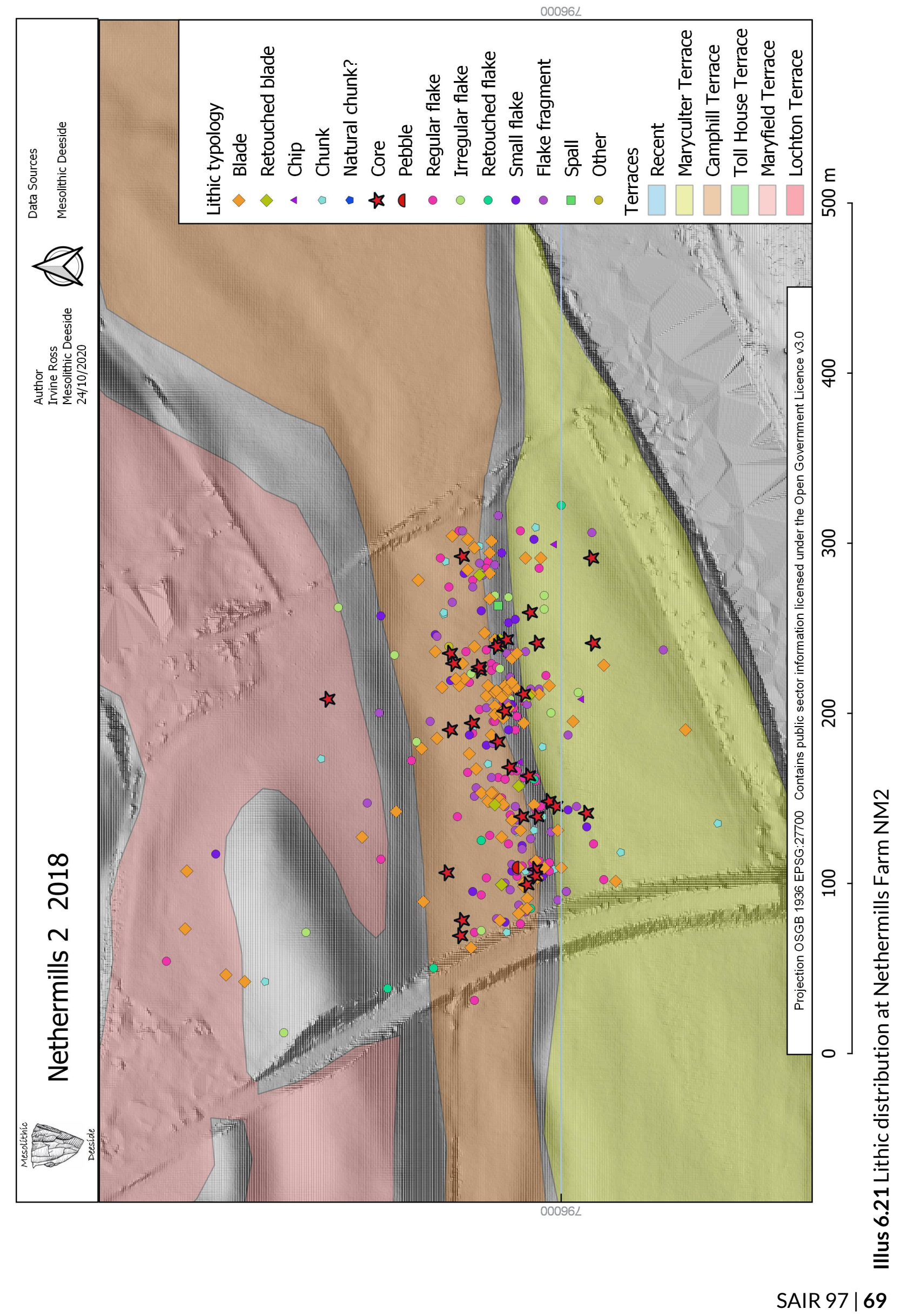


Table 6.16 Lithics from Nethermills Farm 2

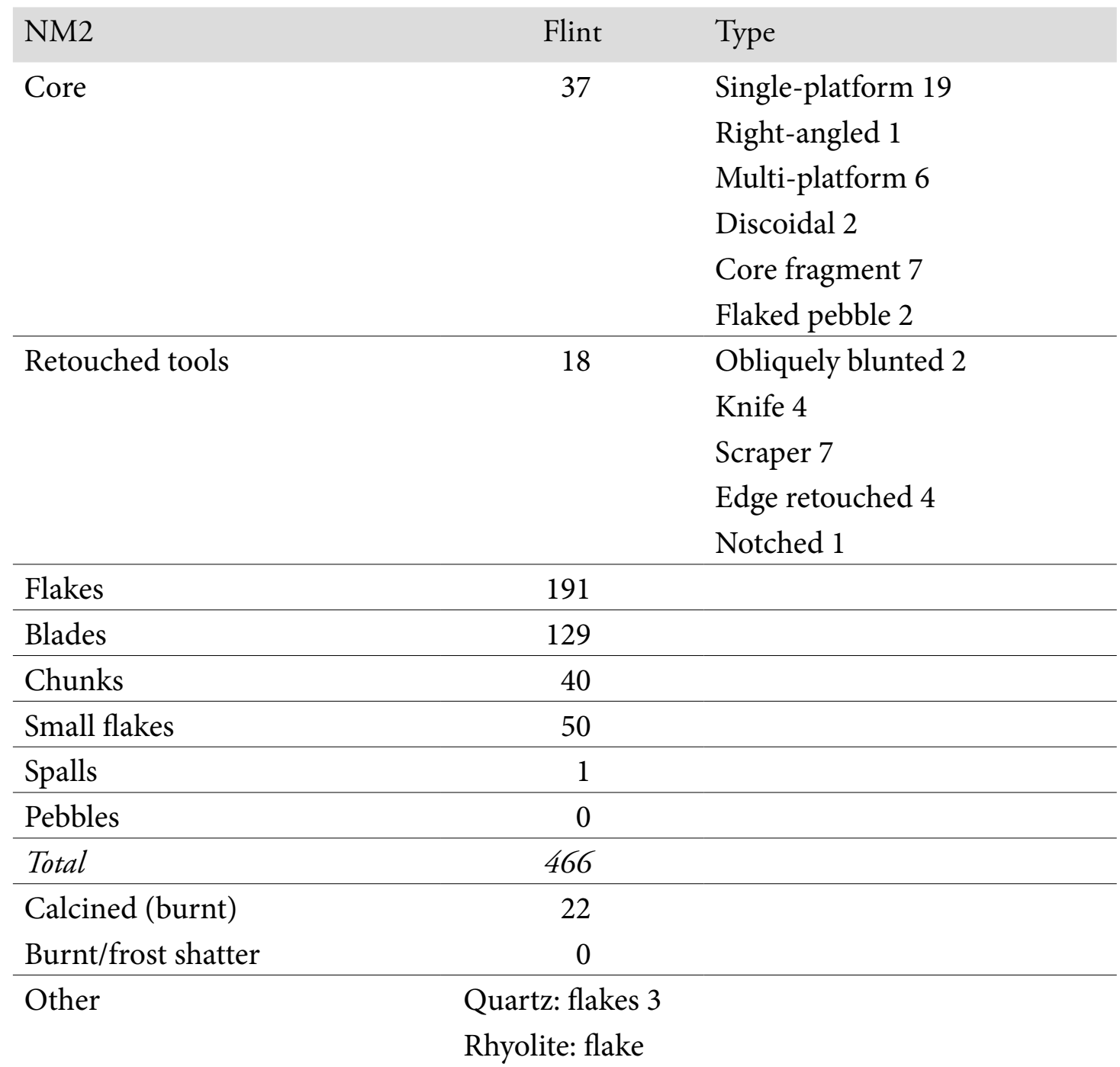

Walked 18 March 2017, 10 and 24 March 2018, 1 and 7 April 2018. Wet weather with rain and snow at first; dry sunshine in April

Existing records: a lithic scatter

Canmore: NO79NE 23

Aberdeenshire Historic Environment Record: NO79NE0021

Both Nethermills Farm 3 (Illus 6.22) and Nethermills Farm 4 (Illus 6.23) lie on a broad section of Camphill Terrace coarse gravel that lies slightly lower than the general trend along the reach. The gravel in field NM4, where test pitting was undertaken, is partially covered by sand, in two broad bands separated by a subdued gravel ridge, likely to be a river bar. The sand may date to deglaciation, but it may represent postglacial, Late Devensian, fluvial sediment. Ten test pits were excavated and sampled in February 2019 for luminescence (OSL) profiling and the interpretation of these for understanding the geomorphology is discussed below (see 7.1.1 'Geomorphology'). Several palaeochannels cross the terrace surface, cutting into the sand. At least two, in the northern parts of the fields, are filled with peat. Pollen-analytical investigation of one channel suggests the basal peat is Early Holocene in date (Ewan 1981; Tipping 2007; Wickham-Jones et al 2017) and thus that the channels were not active by then. Local woodland indicates dry conditions throughout the Holocene, able to support Corylus and later Quercus (Ewan 1981), and it seems that only the highest floods deposited sediment on the terrace surface.

Field NM3 was walked by Grieve in the 1970s, who regarded it as a prolific location but combined 


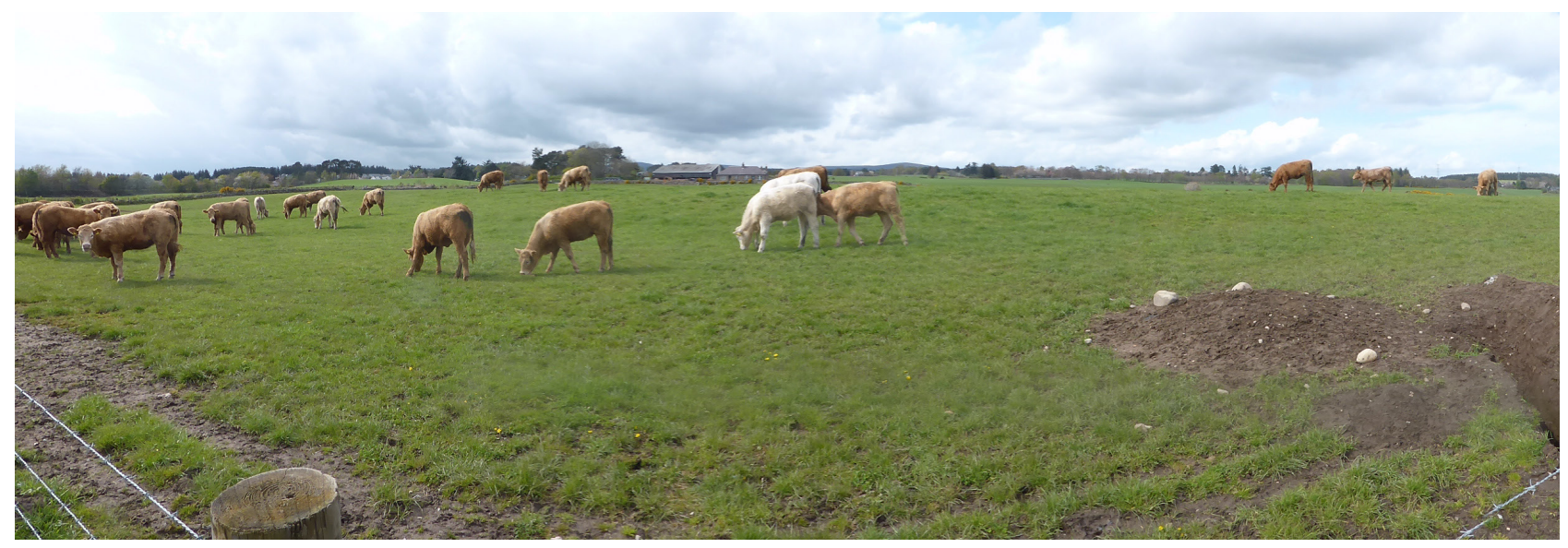

Illus 6.22 Nethermills Farm NM3 from the south

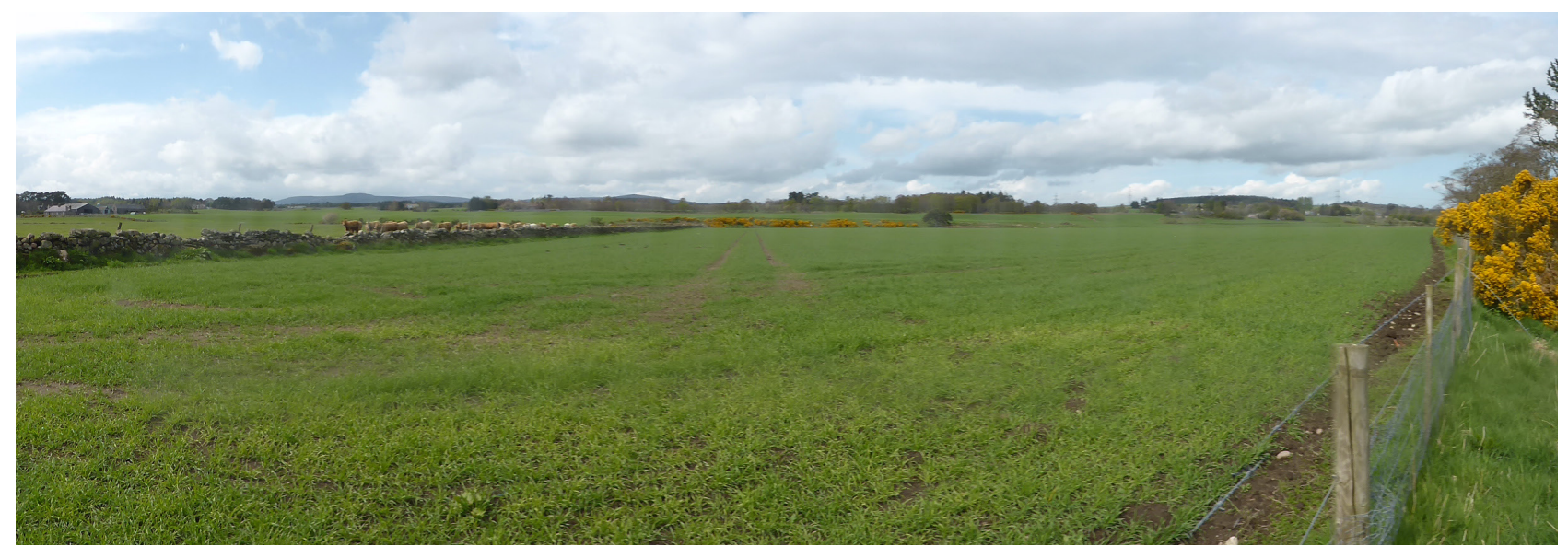

Illus 6.23 Nethermills Farm NM4 from the south-west; the older, higher Maryfield Terrace can be seen running along the centre of the photograph at the back of the lower field surface

the lithics he recovered from NM3 and NM4 into one collection. It has also been walked by OFARS and in 2002 by Duthie of Mesolithic Deeside, who recovered 16 pieces, all blades, flakes and chunks (Table 6.17). It has not, so far, been walked by Mesolithic Deeside. In field NM4, the excavation 1978-81 and test pitting in 2019 (below) indicate that the surface of the field has become increasingly truncated between these two episodes, so that few, if any, features of the sort recorded in the excavation now survive. The archaeological significance of the site has thus declined with time. A total of 3,159 pieces were recovered by fieldwalking in NM4 in 2017 and 2018 (Illus 6.24) and are listed here (Table 6.18); in addition, there is a small assemblage of 433 pieces which was recovered during the test pitting in 2019 and these are covered below in the discussion of the test pitting exercise (see 7.1
'Nethermills Farm (NM4)'). It should be noted that there are other lithic assemblages from these fields and a publication to bring together the whole collection is in preparation (Wickham-Jones 2020a; Wickham-Jones in prep).

These fields have been extensively walked since the 1970s (Wickham-Jones 2020a). It is not possible to plot the density of every collection, but, in general, higher densities reflect the subtle topographic variation with particular concentrations on the gravel bar across the middle of the Camphill Terrace (Illus 6.24). In some instances, lithics occur along the edges of the palaeochannels. Though there is undoubtedly scope for some of the lithics to have been moved during fluvial activity, the recording of surviving Mesolithic and later features below the ploughsoil during excavation between 1978 and 1981 (Wickham-Jones et al 2017) indicates that 


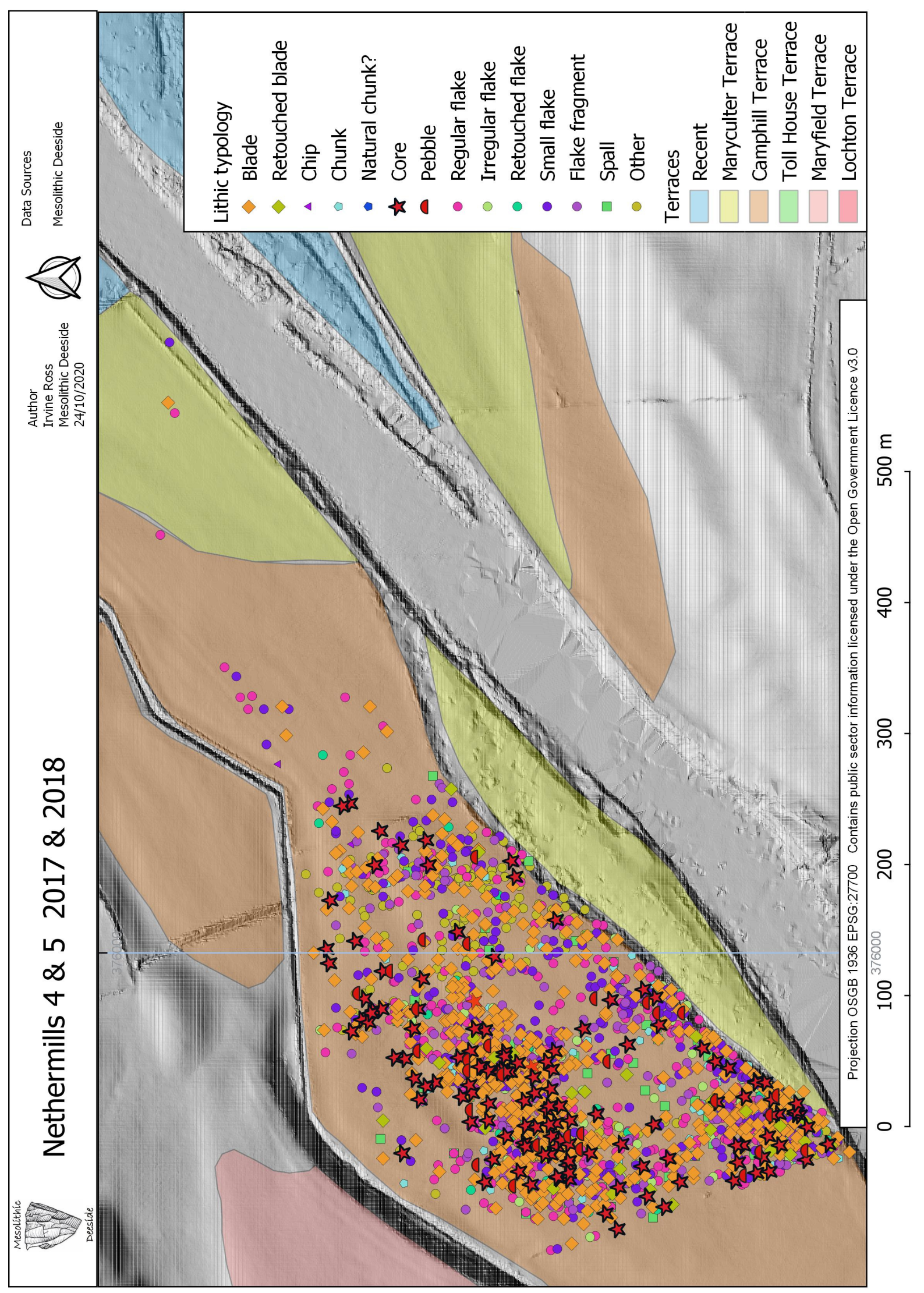

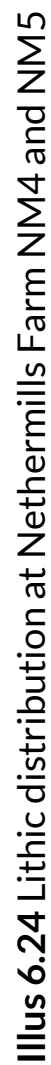


Table 6.17 Lithics from Nethermills Farm 3

\begin{tabular}{lcl} 
NM3 & Flint & Type \\
Core & 0 & \\
\hline Retouched tools & 0 \\
\hline Flakes & 7 \\
\hline Blades & 4 \\
\hline Chunks & 5 \\
\hline Small flakes & 0 \\
\hline Spalls & 0 \\
\hline Pebbles & 0 \\
\hline Total & 16 \\
\hline Calcined (burnt) & 0 \\
Burnt/frost shatter & 0 \\
\hline Other & 0
\end{tabular}

at that time parts of the site were preserved with little disturbance. It may be that human activity in the Mesolithic was focused along the surface of the river bar, which formed a drier island within the braided river channel, itself demarcated by the palaeochannels on either side.

\subsubsection{Nethermills Farm 5 (NM5)}

\section{NGR: NO 7636496771}

7.47 hectares, 7-10 pieces per hectare

Walked 7 April 2018. Warm, dry weather, 20 walkers, $5 \mathrm{~m}$ transects

Existing records: a lithic scatter; a ditch Canmore: NO79NE 99

Aberdeenshire Historic Environment Record: NO79NE0131

Nethermills Farm 5 lies to the east of Nethermills Farm 4 and, though a continuation of the Camphill Terrace, is slightly lower than it. Because it is lower, it is mapped as the Maryculter Terrace. The farmer reports the impact of extensive flooding at times on this field, which has resulted in the erosion of topsoil to the extent that soil had to be imported from elsewhere. Forty-five lithics were recorded (Table 6.19), primarily in the western (higher) part of the field. These included a relatively high percentage of blades to flakes and other indicators of Mesolithic activity.

\subsubsection{Nethermills Farm 6 \& 7 (NM6; NM7)}

c $45 \mathrm{~m} \mathrm{OD}$

NM6

NGR: NO 7636496978

3.44 hectares, $0-10$ pieces per hectare

NM7

NGR: NO 7604996872

3.10 hectares, $10-20$ pieces per hectare

Walked 28 January 2017, 12-15 walkers, $2 \mathrm{~m}$ transects

Existing records: three possible ring ditches and a series of pits

Canmore: NO79NE 48

Aberdeenshire Historic Environment Record: NO79NE0055; NO79NE0145

Fields NM6 and NM7 are set back from the river to the north of NM5, above the Camphill Terrace on a highly dissected surface of the Lochton Sand and Gravel Formation, at their highest point about $50 \mathrm{~m}$ OD. Satellite imagery (Illus 6.25) shows that the surface of the gravel ridge in NM7 and to the west is cut by a series of gullies running downslope towards the river. The slope of these channels indicates that they are postglacial in date. They have not been dated but the Coy Burn, in the centre of the image, lies in a deep gully which extends north to the moraines that mark the maximum extent of the Loch of Park (Illus 4.4). It is likely that the only time the gullies etching into the gravels west of the Coy Burn were active was during the maximum extent of the Loch of Park, during deglaciation: the gullies are essentially overflow channels draining across country to the Dee.

A total of 66 lithics were recorded across these fields (Tables $6.20 \& 6.21$; Illus 6.25) in a distribution that, in NM7, reflects the location of one of the gullies. These assemblages are not large and do not contain material indicative of specific periods; they could reflect activity at any time from Mesolithic through to the Bronze Age. The uniform size distribution of lithics along the gully suggests that this reflects a focus of human activity, in contrast to the pattern in NM6 which is spread more widely. Recent excavation at Nether Park, immediately to the east of NM7, uncovered evidence for activity from the Mesolithic to the Bronze Age, probably in the form of a series of unrelated short-term visits by small groups (Murray \& Murray 2021). 
Table 6.18 Lithics from Nethermills Farm 4

\begin{tabular}{|c|c|c|}
\hline NM4 & Flint & Type \\
\hline \multirow[t]{8}{*}{ Core } & 178 & Single-platform 80 \\
\hline & & Right-angled 9 \\
\hline & & Opposed-platform 8 \\
\hline & & Multi-platform 24 \\
\hline & & Discoidal 1 \\
\hline & & Core fragment 21 \\
\hline & & Bipolar 9 \\
\hline & & Flaked pebble 26 \\
\hline \multirow[t]{8}{*}{ Retouched tools } & 94 & Microlith 17 \\
\hline & & Obliquely blunted blade 14 \\
\hline & & Scraper 32 \\
\hline & & Edge retouched 16 \\
\hline & & Knife form 4 \\
\hline & & Notched 3 \\
\hline & & Awl 5 \\
\hline & & Microburin 3 \\
\hline Flakes & 1,198 & \\
\hline Blades & 769 & \\
\hline Chunks & 230 & \\
\hline Small flakes & 556 & \\
\hline Spalls & 133 & \\
\hline Pebbles & 0 & \\
\hline Total & 3,158 & \\
\hline Calcined (burnt) & 180 & \\
\hline Burnt/frost shatter & 89 & \\
\hline
\end{tabular}

Other

Rhyolite: pebble 
Table 6.19 Lithics from Nethermills Farm 5

\begin{tabular}{lcl} 
NM5 & Flint & Type \\
Core & 2 & Single-platform 2 \\
\hline Retouched tools & 4 & $\begin{array}{l}\text { Scraper 2 } \\
\text { Obliquely blunted blade 1 } \\
\text { Bifacial 1 }\end{array}$ \\
\hline Flakes & 16 & \\
\hline Blades & 9 & \\
\hline Chunks & 1 & \\
\hline Small flakes & 12 & \\
\hline Spalls & 1 & \\
\hline Pebbles & 0 & \\
\hline Total & 45 & \\
\hline Calcined (burnt) & 1 & \\
Burnt/frost shatter & 0 & \\
\hline Other & 0 &
\end{tabular}

Table 6.20 Lithics from Nethermills Farm 6

\begin{tabular}{lrl} 
NM6 & Flint & Type \\
Core & 1 & Core fragment \\
\hline Retouched tools & 3 & Scraper 3 \\
\hline Flakes & 13 & \\
\hline Blades & 1 & \\
\hline Chunks & 0 & \\
\hline Small flakes & 2 & \\
\hline Spalls & 2 & \\
\hline Pebbles & 1 & \\
\hline Total & 23 & \\
\hline Calcined (burnt) & 2 & \\
Burnt/frost shatter & 2 & \\
\hline Other & 0 &
\end{tabular}




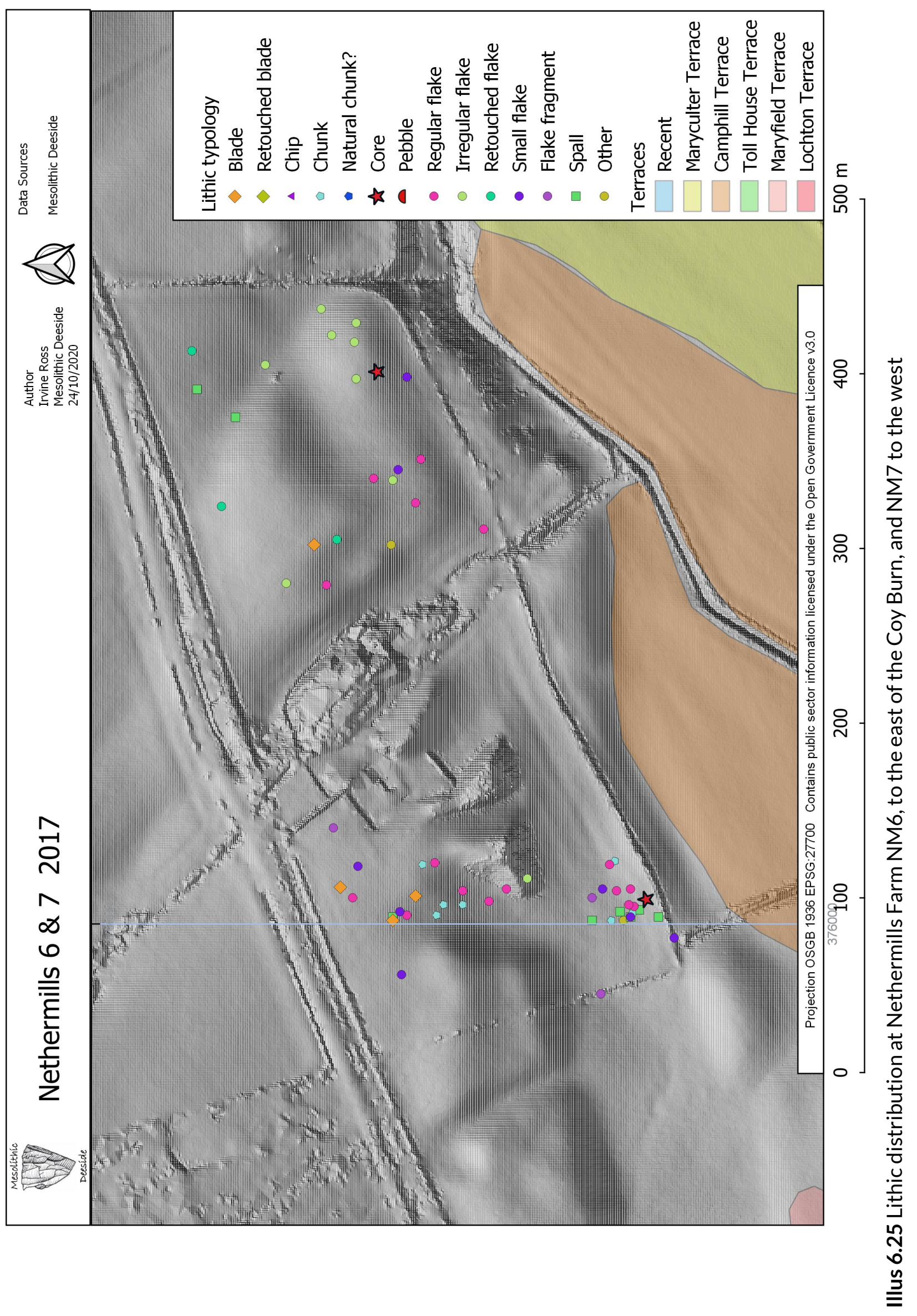


Table 6.21 Lithics from Nethermills Farm 7

\begin{tabular}{lcl} 
NM7 & Flint & Type \\
Core & 1 & Single-platform \\
\hline Retouched tools & 0 & \\
\hline Flakes & 15 & \\
\hline Blades & 5 & \\
\hline Chunks & 7 & \\
\hline Small flakes & 7 & \\
\hline Spalls & 7 & \\
\hline Pebbles & 0 & \\
\hline Total & 42 & \\
\hline Calcined (burnt) & 9 & \\
Burnt/frost shatter & 5 & \\
\hline Other & Quartz flake
\end{tabular}

\subsubsection{Nethermills Farm 9 (NM9)}

NGR: NO 7549996624

c $45 \mathrm{~m}$ OD

11.32 hectares, $<1$ piece per hectare

Walked 30 August 2017

Nethermills Farm 9 lies on the Lochton Terrace surface between Nethermills Farm 2 and Upper Mills 1 . The surface is uneven due to a high number of meltwater channels which criss-cross it. One flint flake was collected.

\subsection{Park Smiddy (PS1; PS2)}

\section{5-50m OD}

PS1

NGR: NO 77841 97846;

4.01 hectares, $10-20$ pieces per hectare

PS2

NGR: NO 7756197641

2.25 hectares, $10-20$ pieces per hectare

Walked 4 and 10 February 2018, bright sunny weather, 14 walkers, $2 \mathrm{~m}$ transects

Aberdeenshire Historic Environment Record: NO79NE0132

Park Smiddy 1 and 2 are two fields set back some $500 \mathrm{~m}$ to the north of the river, on an eroded surface of the Maryfield Terrace. A total of 102 lithics were recovered, scattered mainly across the central and higher part of the fields (Tables $6.22 \&$
6.23; Illus 6.26), on the least eroded fragments. The assemblages are dominated by flakes and there is only one retouched piece, a scraper. The presence of bipolar cores is generally indicative of flint working in the Late Neolithic, though bipolar working also occurred in small quantity on some Early Neolithic sites along the Dee, as at Warren Field, Crathes (Warren 2009: 102).

\subsection{Potarch (PT1)}

NGR: NO 6061097436

3.38 hectares, 26 pieces per hectare

Walked 12 and 29 May 2017, 2 June 2017. Dry and sunny, late ploughed and late sown but well weathered, 1 walker, 3-4m transects

Aberdeenshire Historic Environment Record: NO69NW0065

The field at Potarch lies on the south bank of the Dee (Illus 6.27), around $2.5 \mathrm{~km}$ downstream of the Kincardine O'Neil fields but in a contrasting setting, within a narrow bedrock-dominated gorge of the river, $c 100 \mathrm{~m}$ upstream of the rapids of Jock Young's Leap. The field, just over $400 \mathrm{~m}$ long and around $100 \mathrm{~m}$ wide, was mapped by the British Geological Survey (1996) as a lateral equivalent of the Camphill Terrace. Eighty-eight lithics were recovered (Table 6.24), mainly indicative of activity in the Mesolithic. LiDAR data and Google Earth imagery, particularly from 2007 when the field was ploughed, show the 


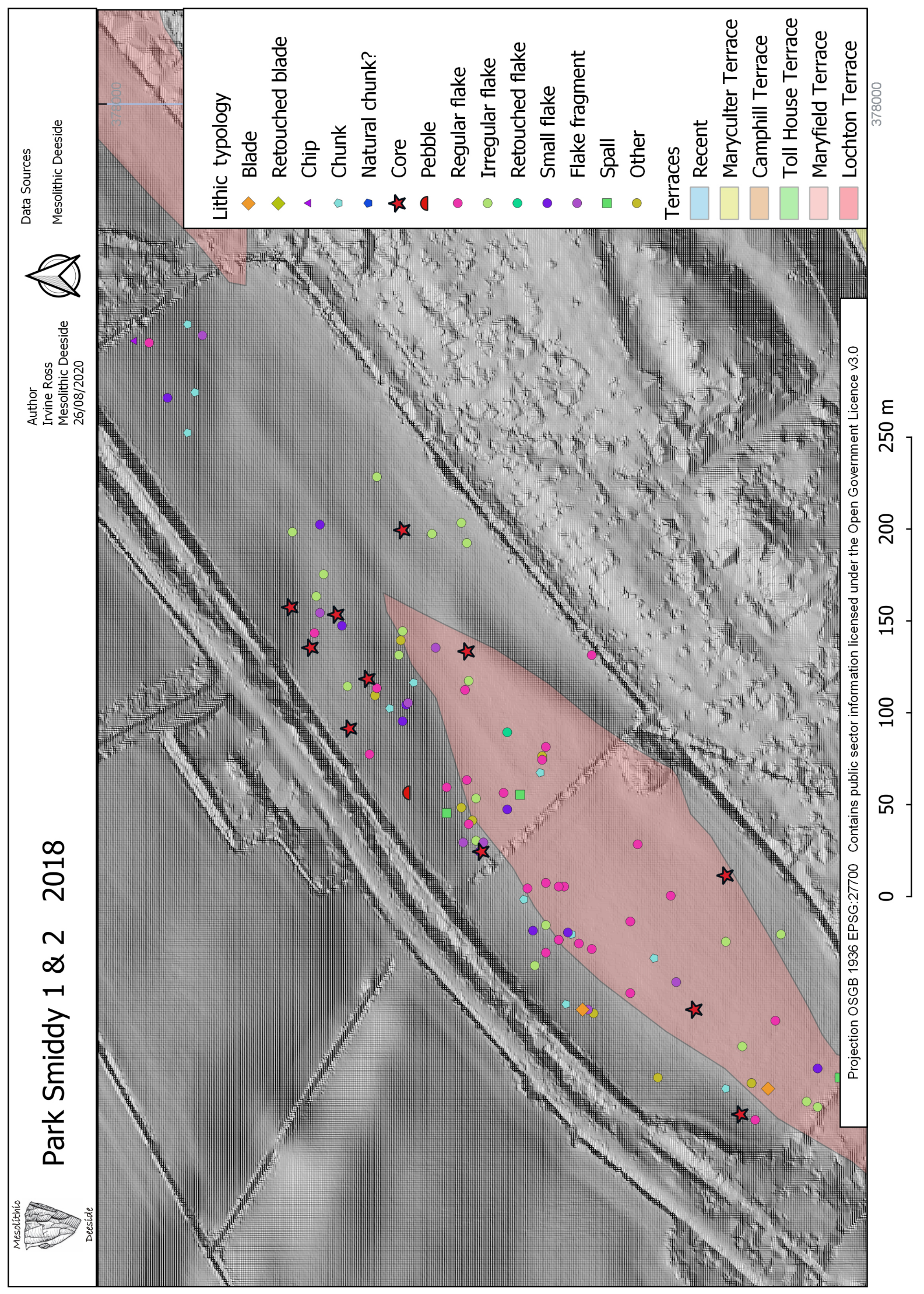

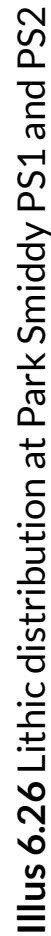


Table 6.22 Lithics from Park Smiddy 1

\begin{tabular}{lcl} 
Park Smiddy 1 (PS1) & Flint & $\begin{array}{l}\text { Type } \\
\text { Core }\end{array}$ \\
& 9 & $\begin{array}{l}\text { Single-platform 4 } \\
\text { Multi-platform 2 } \\
\text { Core fragment 2 } \\
\text { Flaked pebble 1 }\end{array}$ \\
\hline Retouched tools & 1 & Scraper \\
\hline Flakes & 28 & \\
\hline Blades & 4 & \\
\hline Chunks & 8 & \\
\hline Small flakes & 7 & \\
\hline Spalls & 3 & \\
\hline Pebbles & 1 & \\
\hline Total & 61 & \\
\hline Calcined (burnt) & 0 & \\
Burnt/frost shatter & 3 & \\
\hline Other & 0 &
\end{tabular}

Table 6.23 Lithics from Park Smiddy 2

\begin{tabular}{lcl} 
Park Smiddy 2 (PS2) & Flint & $\begin{array}{l}\text { Type } \\
\text { Core }\end{array}$ \\
& 3 & $\begin{array}{l}\text { Multi-platform 1 } \\
\text { Core fragment 1 } \\
\text { Bipolar 1 }\end{array}$ \\
\hline Retouched tools & 0 & \\
\hline Flakes & 27 & \\
\hline Blades & 3 & \\
\hline Chunks & 5 & \\
\hline Small flakes & 3 & \\
\hline Spalls & 0 & \\
\hline Pebbles & 0 & \\
\hline Total & 41 & \\
\hline Calcined (burnt) & 0 & \\
Burnt/frost shatter & 3 & \\
\hline Other & 0
\end{tabular}




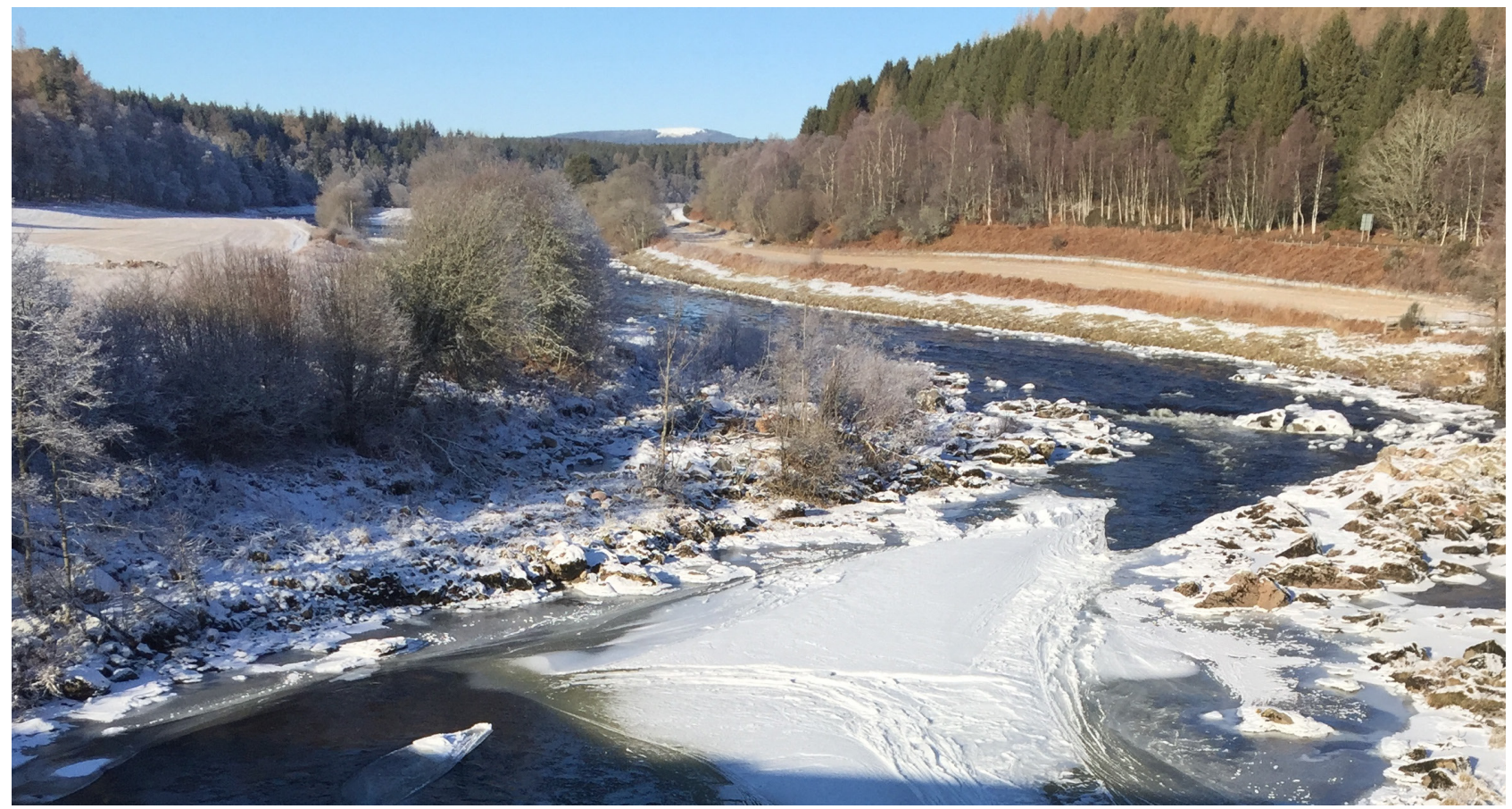

Illus 6.27 The field at Potarch, seen on the left of the photograph, from the east. The rapids at Jock Young's Leap lie in the foreground

strongly linear distribution of the lithic scatter to border, to the south, a single, nearly continuous c $9 \mathrm{~m}$ wide palaeochannel parallel to the present Dee, black in colour and almost certainly peat-filled (Illus 6.28). A relation between the lithics and the palaeochannel seems clear, although soil colour changes might suggest that sediment north of the channel is different, probably younger and perhaps burying artefacts. In addition, a line of roughly circular anomalies is visible on satellite images such as Google Earth (Illus 6.29), along the lower edge of the terrace.

\subsection{Upper Balfour (UB)}

Various locations have been fieldwalked at Upper Balfour and are combined below. All lie on a slope in glacial till. The site comprises several fields lying to the south of the site at Nether Balfour. All were walked by a single walker as reconnaissance exercises and this fieldwalking did not involve the use of dGPS to plot finds.

\subsubsection{Upper Balfour 30 acre (UB1)}

NGR: NO 7926797073

12.56 hectares

\subsubsection{Upper Balfour Middle East (UB2)}

NGR: NO 7897896595

8.09 hectares

Walked 24 March 2002 and 12 May 2003

6.15.3 Upper Balfour Steading (UB3)

NGR: NO 7881196677

4.82 hectares

Walked 30 March 2002, 1 and 2 April 2002

\subsubsection{Upper Balfour Dam Park (UB4)}

NGR: NO 7858596477

7.27 hectares

Walked in winter 1999, spring 2000, November 2000, 17 November 2001, 27 January 2002, 5 April 2002, 1 May 2002, 17 May 2003

Existing records: two areas of darkened earth, bronze axe

Aberdeenshire Historic Environment Record: NO79NE0134; NO79NE0020

\subsubsection{Upper Balfour 22 Acre (UB5)}

NGR: NO 7834996379

9.46 hectares 


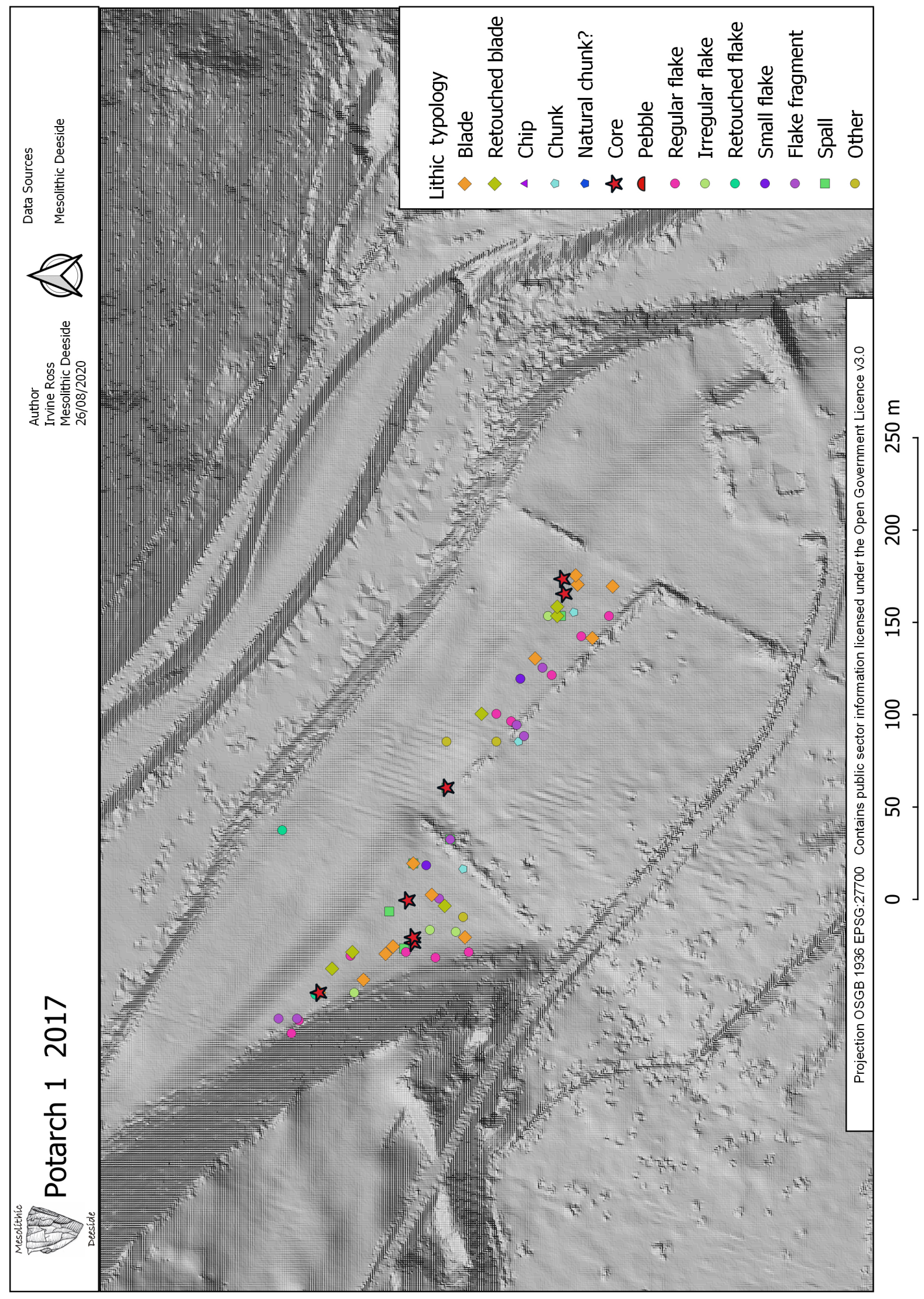

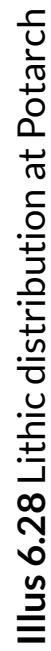



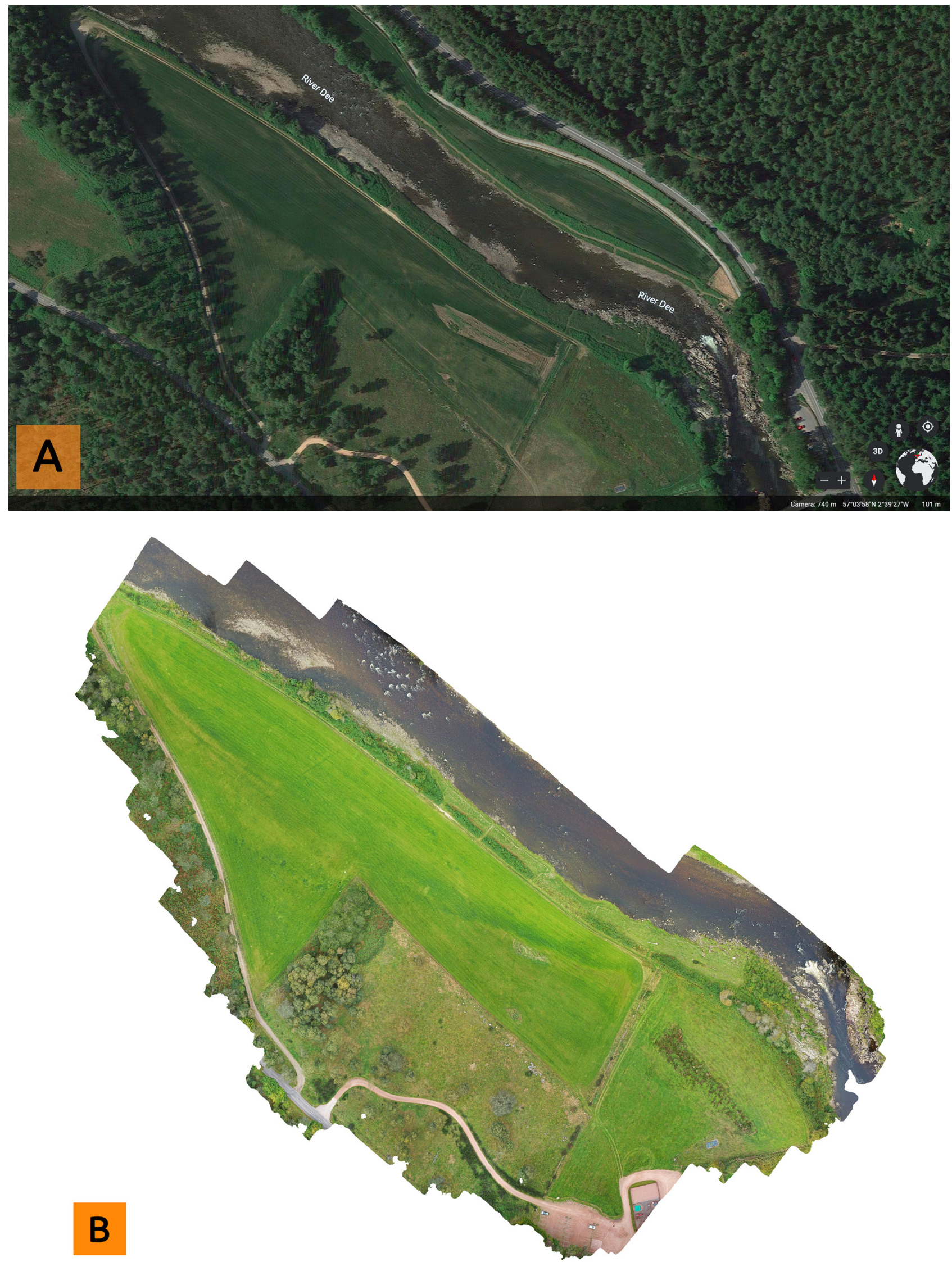

Illus 6.29 Aerial imagery of the field at Potarch shows the palaeochannels and the circular anomalies. A Google Earth imagery 2020 (c) CNES/Airbus Getmapping plc Maxar Technologies; B Drone image September 2020 
Table 6.24 Lithics from Potarch

\begin{tabular}{lcl} 
Potarch (PT1) & Flint & $\begin{array}{l}\text { Type } \\
\text { Core }\end{array}$ \\
& 7 & $\begin{array}{l}\text { Single-platform 3 } \\
\text { Core fragment 3 } \\
\text { Bipolar 1 }\end{array}$ \\
\hline Retouched tools & 11 & $\begin{array}{l}\text { Obliquely blunted blade 2 } \\
\text { Notched blade } 4 \\
\text { End scraper 2 } \\
\text { Edge retouched 2 } \\
\text { Awl 1 }\end{array}$ \\
& & \\
\hline Flakes & 38 & \\
\hline Blades & 13 & \\
\hline Chunks & 10 & \\
\hline Small flakes & 3 & \\
\hline Spalls & 6 & \\
\hline Pebbles & 0 & \\
\hline Total & 88 & \\
\hline Calcined (burnt) & 22 & \\
Burnt/frost shatter & 3 & \\
\hline Other & 0 &
\end{tabular}

Walked 17, 20, 24, 26 June 2000, 28 July 2001 field then in grass -26 and 29 June 2006

\subsubsection{Upper Balfour Woodlands (UB6)}

NGR: NO 7871896198

7.23 hectares

Walked May 2001, 20 April 2002, May 2002, May 2003, March 2014

Existing records: polished stone axe and possible Mesolithic blades were found in this field (and not as recorded by Canmore)

Canmore: NO79NE 102

Aberdeenshire Historic Environment Record: NO79NE0124

\subsubsection{Upper Balfour Football Pitch (UB7)}

NGR: NO 7829895848

0.73 hectares

2 lithics collected when football pitch was being reseeded, 1 July 2000

The assemblage of 92 pieces from Upper Balfour is mainly indicative of activity in the Late Neolithic and Early Bronze Age (Table 6.25).

\subsection{Upper Mills $1 \& 2$ (UM1; UM2)}

c $50 \mathrm{~m} \mathrm{OD}$

UM1

NGR: NO 7541996657

2.35 hectares, $0-10$ pieces per hectare

Walked 25 February 2017, 12-15 walkers, $2 \mathrm{~m}$ transects Aberdeenshire Historic Environment Record: NO79NE0129

UM2

NGR: NO 7556897112

5.91 hectares, $0-10$ pieces per hectare

Walked 27 January 2018. Sunny but with a cold wind and muddy underfoot. 15 walkers, $2 \mathrm{~m}$ transects across $70 \%$ of the field working from the eastern end

Existing record: cup marked stone

Canmore: NO79NE 16

Aberdeenshire Historic Environment Record: NO79NE0133 
Table 6.25 Lithics from Upper Balfour

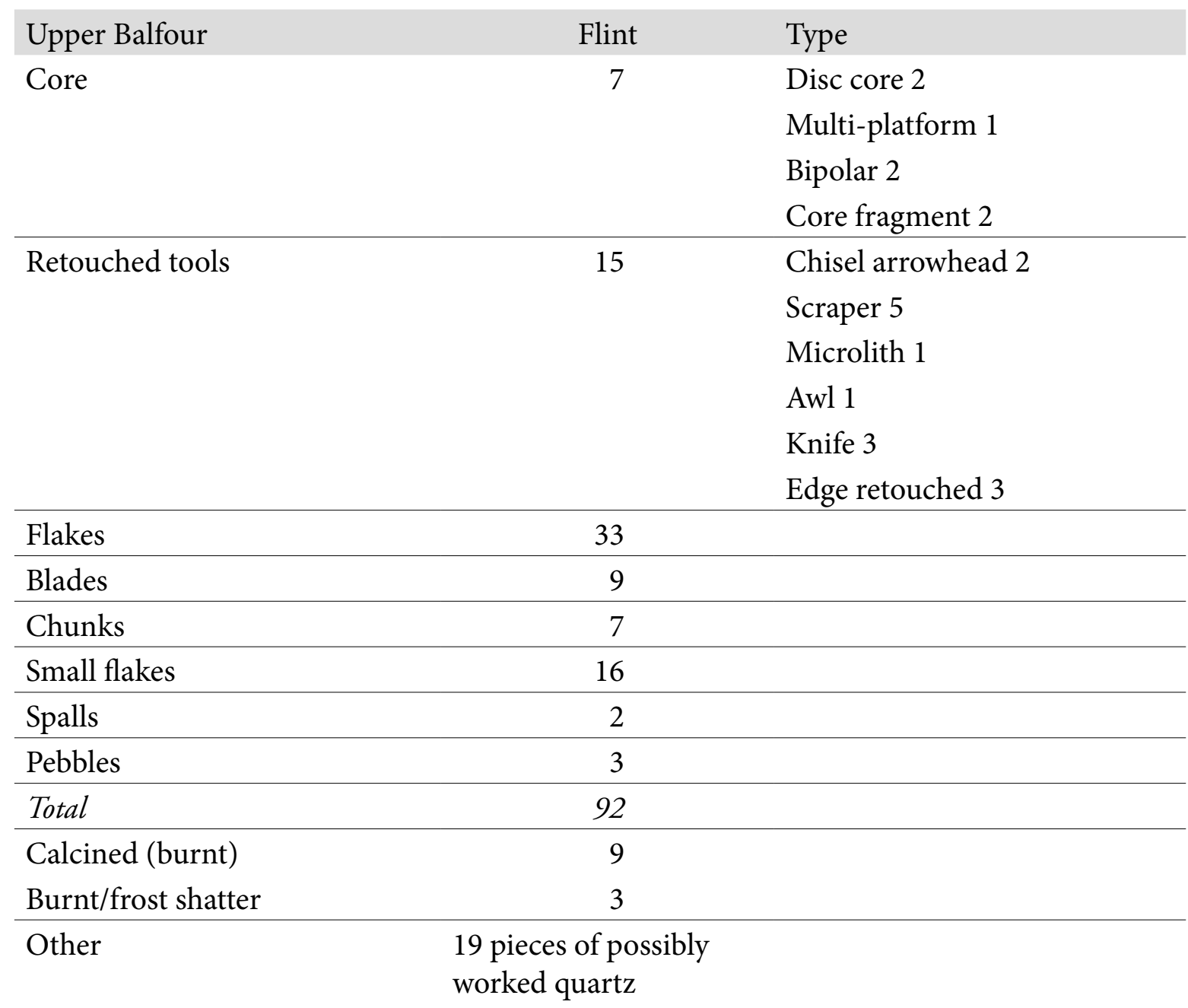

The field at Upper Mills 1 lies to the east of Candieshill on the surface of the Lochton Terrace which is hummocky and uneven here. Five lithics were collected (Table 6.26). Upper Mills 2 lies slightly higher, in till, and 15 lithics were collected (Table 6.27), spread across the field (Illus 6.30).

\subsection{Wester Durris (WD)}

\section{NGR: NO 7641396325}

48.56 hectares, $10-20$ pieces per hectare in WD1 and WD2

Walked August 2000, September 2000, January 2001, January 2002, March 2002, March 2003, March 2005, March 2017, 12 and 20 January 2019, mixed weather. 15-20 walkers in 2019, $2 \mathrm{~m}$ transects

Aberdeenshire Historic Environment Record: NO79NE0127; NO79NE0128
The site at Wester Durris occupies 11 fields on the south side of the River Dee, opposite Nethermills Farm. These fields adjoin those of Cairnballoch and Nether Balfour which lie immediately to the east. The surface of the Wester Durris fields falls some $17 \mathrm{~m}$ towards the river. Together they cover a variety of superficial deposits. The southern parts of fields WD1 and WD2 slope because they are in heavily channelled and hummocky till. At the base of this slope, around $35.5 \mathrm{~m} \mathrm{OD}$, is a narrow sliver of the Camphill Terrace, $c 60 \mathrm{~m}$ wide at most. This narrows eastward, cut out by a shallow palaeochannel which forms the southern edge of an extensive fragment of the Maryculter Terrace and, next to the Dee, recent vegetated point bar deposits. Most of field WD3, and all of field GLCh are in hummocky glaciofluvial deposits of the Lochton Sand and Gravel Formation. Field GLHF is a terrace on the Sheeoch Burn and 
Table 6.26 Lithics from Upper Mills 1

\begin{tabular}{|c|c|}
\hline Upper Mills 1 (UM1) & Flint Type \\
\hline Core & 0 \\
\hline Retouched tools & 0 \\
\hline Flakes & 3 \\
\hline Blades & 0 \\
\hline Chunks & 1 \\
\hline Small flakes & 0 \\
\hline Spalls & 1 \\
\hline Pebbles & 0 \\
\hline Total & 5 \\
\hline Calcined (burnt) & 2 \\
\hline Burnt/frost shatter & 0 \\
\hline Other & 0 \\
\hline
\end{tabular}

Table 6.27 Lithics from Upper Mills 2

\begin{tabular}{lcl} 
Upper Mills 2 (UM2) & Flint & Type \\
Core & 1 & Bipolar 1 \\
\hline Retouched tools & 0 & \\
\hline Flakes & 9 & \\
\hline Blades & 1 & \\
\hline Chunks & 2 & \\
\hline Small flakes & 1 & \\
\hline Spalls & 0 & \\
\hline Pebbles & 1 & \\
\hline Total & 15 & \\
\hline Calcined (burnt) & 1 & \\
Burnt/frost shatter & 0 & \\
\hline Other & 0
\end{tabular}

cannot strictly be correlated with the Dee terraces, although the British Geological Survey mapped this as equivalent to the Camphill Terrace.

A general scatter of 186 lithics runs across the fields (Tables 6.28, 6.29, 6.30 \& 6.31; Illus 6.31; note early fieldwalking did not plot finds by dGPS). They are common, unusually, on the till as well as on the Camphill Terrace; few are found on the Maryculter Terrace, and these lie at the break of slope leading to the Camphill Terrace, probably deposited in colluvium. The scatter is dominated by later elements, suggestive of Late Neolithic and Bronze Age activity. An unusual end scraper provides a notable exception, likely to date to the Late Upper Palaeolithic and fashioned on a broad blade of distinctive banded flint. Many of the other pieces from WD would be more at home in a Late Neolithic context, however, and the assemblage included pieces made of a grey flint that is likely to have been imported to the area at this period. 


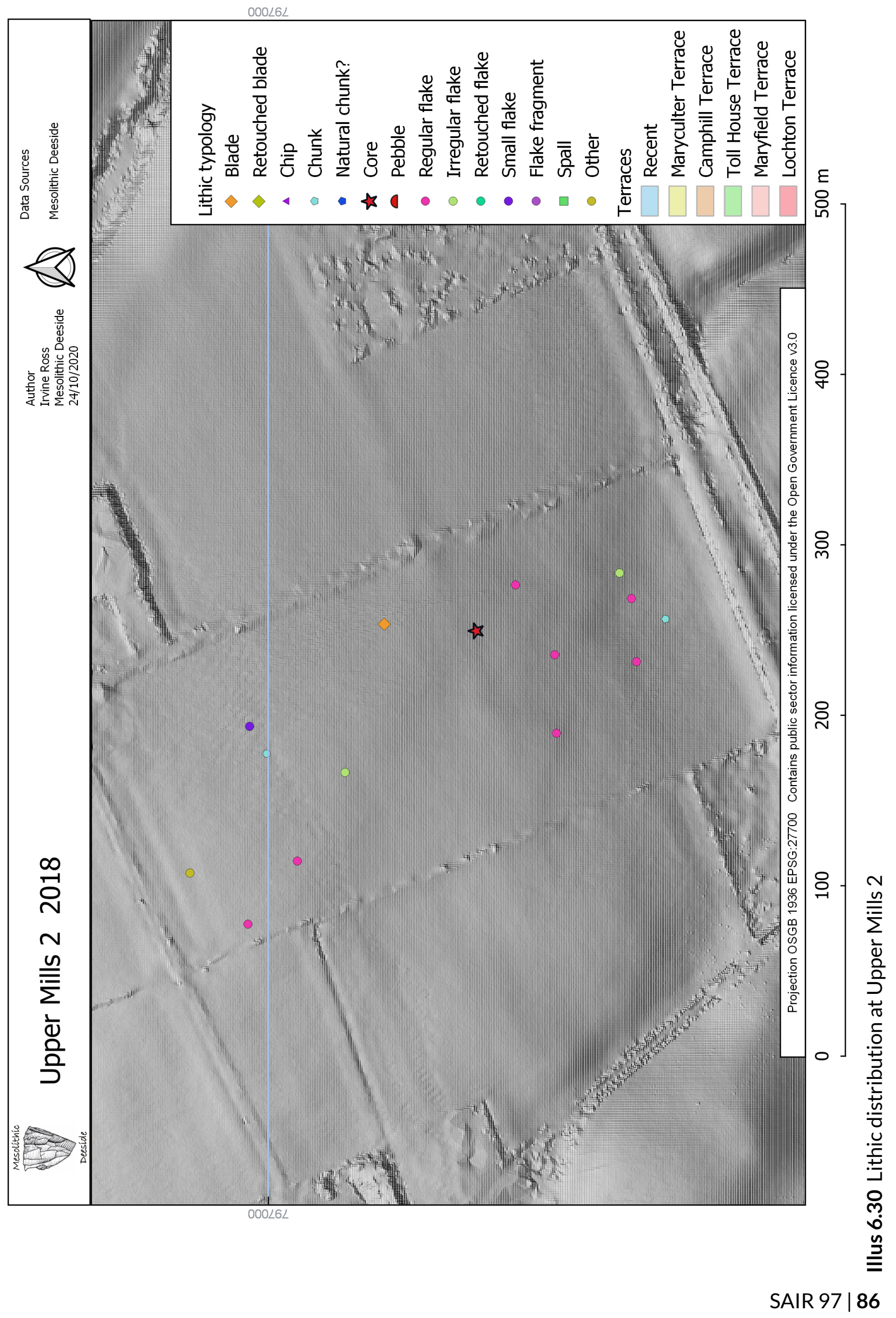




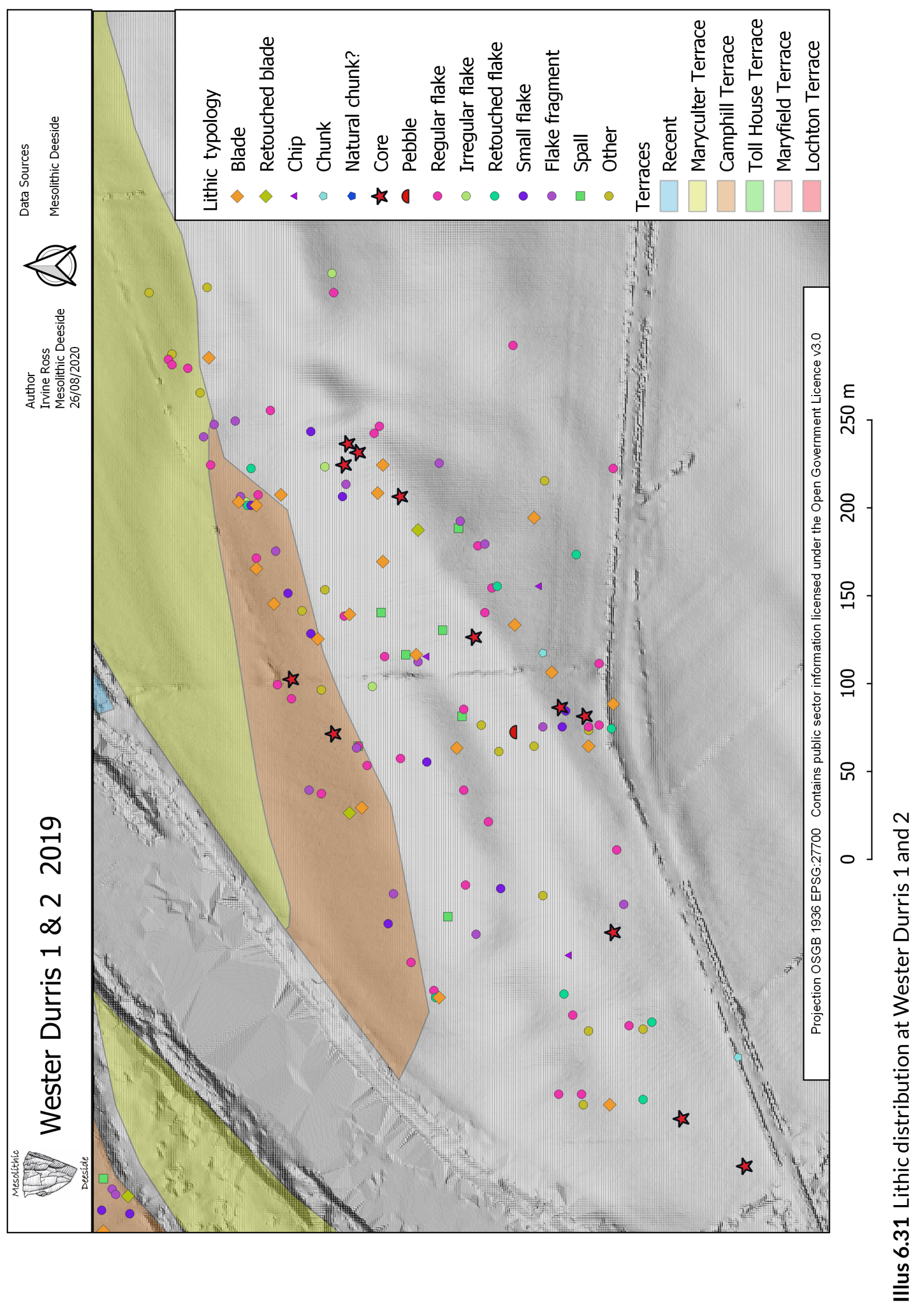


Table 6.28 Lithics from Wester Durris

\begin{tabular}{|c|c|c|}
\hline $\begin{array}{l}\text { Wester Durris (WD, GLHF, } \\
\text { GLCh) }\end{array}$ & Flint & Type \\
\hline \multirow[t]{3}{*}{ Core } & 3 & Single-platform 1 \\
\hline & & Bipolar 1 \\
\hline & & Core fragment 1 \\
\hline \multirow[t]{6}{*}{ Retouched tools } & 8 & Awl 1 \\
\hline & & Knife form 2 \\
\hline & & Edge retouched 2 \\
\hline & & End scraper 1 \\
\hline & & Spokeshave 1 \\
\hline & & Strike-a-light 1 \\
\hline Flakes & 16 & \\
\hline Blades & 3 & \\
\hline Chunks & 5 & \\
\hline Small flakes & 3 & \\
\hline Spalls & 2 & \\
\hline Pebbles & 5 & \\
\hline Total & 45 & \\
\hline Calcined (burnt) & 3 & \\
\hline Burnt/frost shatter & 1 & \\
\hline Other & oal fr & \\
\hline
\end{tabular}


Table 6.29 Lithics from Wester Durris 1

\begin{tabular}{lcl} 
Wester Durris 1 & Flint & $\begin{array}{l}\text { Type } \\
\text { Core }\end{array}$ \\
& 6 & $\begin{array}{l}\text { Single-platform 2 } \\
\text { Bipolar 1 } \\
\text { Multi-platform 2 } \\
\text { Flaked chunk 1 }\end{array}$ \\
\hline Retouched tools & 7 & $\begin{array}{l}\text { Knife form 1 } \\
\text { Scraper 2 } \\
\text { Edge retouched 2 } \\
\text { Invasively flaked piece 1 } \\
\text { Knife reused as bipolar core 1 }\end{array}$ \\
& & \\
\hline Flakes & & \\
\hline Blades & 27 & \\
\hline Chunks & 7 & \\
\hline Small flakes & 3 & \\
\hline Spalls & 5 & \\
\hline Pebbles & 3 & \\
\hline Total & 1 & \\
\hline Calcined (burnt) & 59 & \\
Burnt/frost shatter & 3 & \\
\hline Other & 2 & \\
\hline
\end{tabular}


Table 6.30 Lithics from Wester Durris 2

\begin{tabular}{lcl} 
Wester Durris 2 & Flint & $\begin{array}{l}\text { Type } \\
\text { Core }\end{array}$ \\
& 6 & $\begin{array}{l}\text { Single-platform 2 } \\
\text { Multi-platform 1 } \\
\text { Core fragment 2 } \\
\text { Flaked pebble 1 }\end{array}$ \\
\hline Retouched tools & 5 & $\begin{array}{l}\text { Scraper 3 } \\
\text { Knife form 1 } \\
\text { Leaf point 1 }\end{array}$ \\
\hline Flakes & & \\
\hline Blades & 32 & \\
\hline Chunks & 14 & \\
\hline Small flakes & 6 & \\
\hline Spalls & 5 & \\
\hline Pebbles & 4 & \\
\hline Total & 0 & \\
\hline Calcined (burnt) & 72 & \\
Burnt/frost shatter & 9 & \\
\hline Other & 1 & \\
\hline
\end{tabular}

Table 6.31 Lithics from Wester Durris E

\begin{tabular}{lcl} 
Wester Durris E (Kirkton Fields) & Flint & Type \\
Core & 1 & Core fragment \\
\hline Retouched tools & 0 & \\
\hline Flakes & 2 & \\
\hline Blades & 2 & \\
\hline Chunks & 4 \\
\hline Small flakes & 0 \\
\hline Spalls & 0 \\
\hline Pebbles & 0 \\
\hline Total & 9 \\
\hline Calcined (burnt) & 1 \\
\hline Burnt/frost shatter & 0 \\
\hline Other & Rhyolite: fragment of \\
& spherulitic rhyolite? \\
& Quartz: chunks 2
\end{tabular}




\section{TEST PITTED SITES}

\subsection{Nethermills Farm (NM4)}

NGR: NO 7606996524

Test pitting took place at Nethermills Farm, in field NM4, over four days at the end of February 2019, during a period of unusually warm sunny weather. The team comprised members of Mesolithic Deeside together with students from the University of Aberdeen. The aim of the test pitting was to assess the preservation of Mesolithic and other archaeology across the field in order to inform future planning and land management decisions as well as archaeological potential and priorities.

\subsubsection{Geomorphology}

\section{Tim Kinnaird \& Richard Tipping}

Nethermills Farm 4 (Illus 7.1) lies on a broad section of the Camphill Terrace comprising coarse gravels that lie slightly lower than the general trend along this reach of the river. The gravel here is partially covered by sand, in two broad bands that run roughly south-west/north-east and are separated by a subdued gravel ridge, likely to be a river bar. The sand may date to deglaciation, but it may represent postglacial, Late Devensian, fluvial sediment, laid down when the river crossed this surface. Ten of the test pits were sampled for optically stimulated luminescence (OSL) profiling (Munyikwa et al 2020) to test whether these sands across the terrace surface were of different relative ages: five OSL profiles are depicted in Illus 7.2 in relation to the southern and northern sand sheets and the intervening gravel ridge. Luminescence results from energy retained in certain minerals, typically quartz and feldspar, as a consequence of naturally occurring ionising radiation in both the sample and their environment. Luminescence grows in situ: so, net signal intensities may act as a proxy for age, with older materials having larger signal intensities.

The detail of the interpretation is complex, but it is possible to conclude that the northern sand sheet on the terrace began to accumulate first,

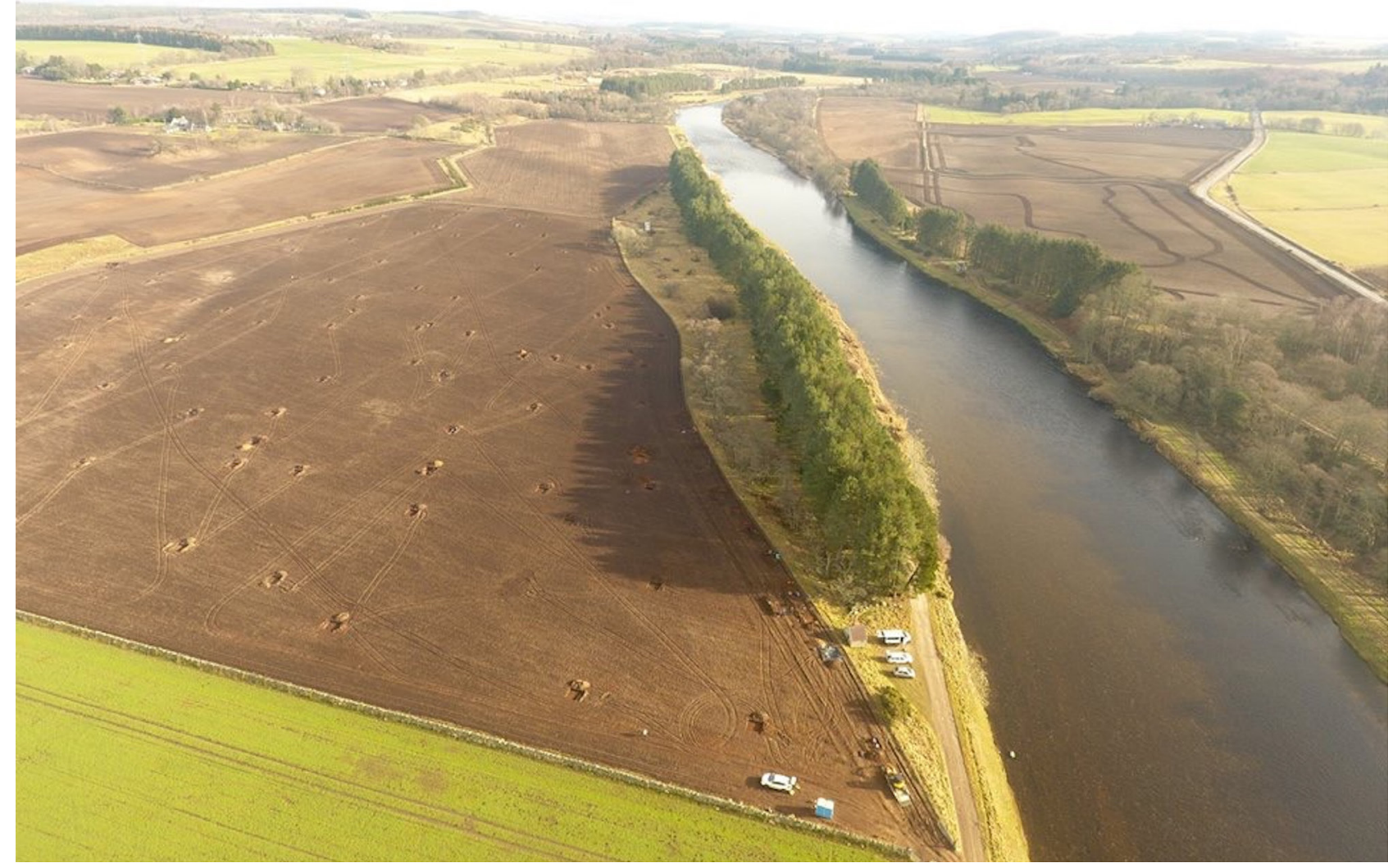

Illus 7.1 Nethermills Farm, NM4, during test pitting from the west 

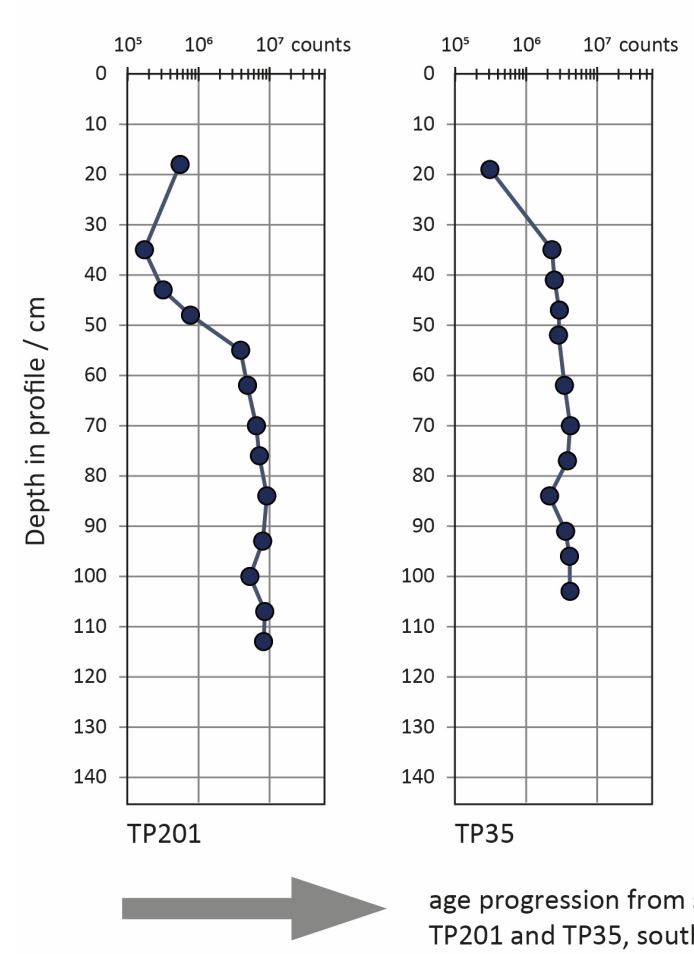

OSL net signal intensities
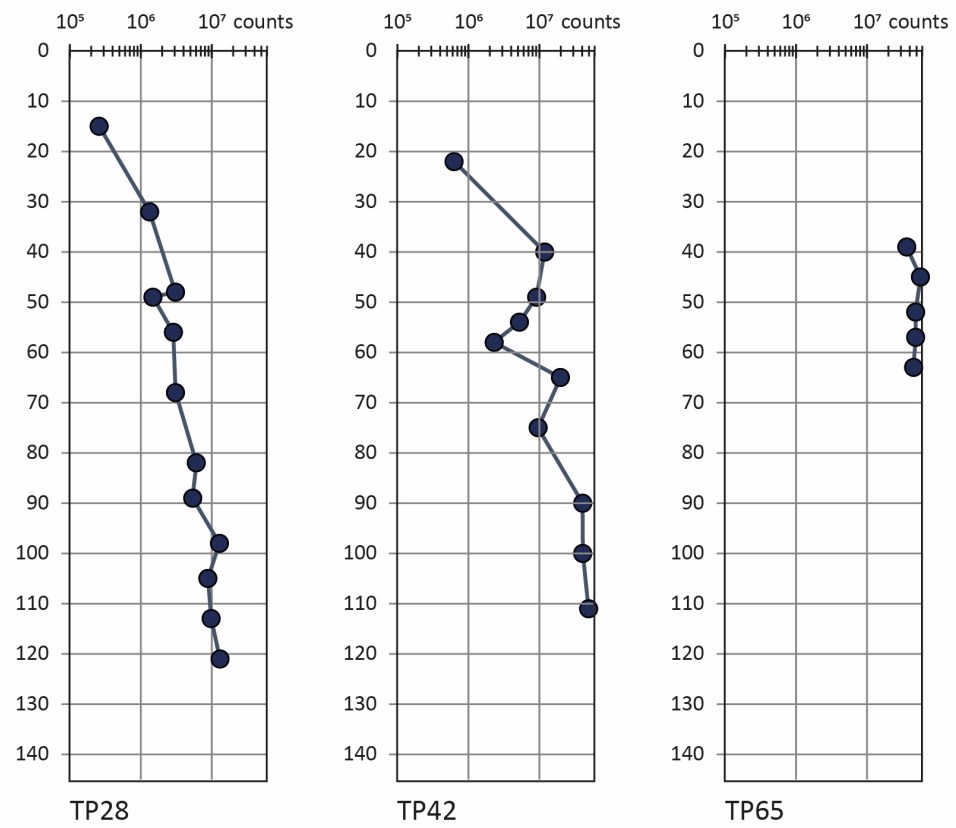

age progression from south to north across Camphill Terrace

TP201 and TP35, southern sands; TP28, gravel ridge; TP42 and TP65, northern sands

Illus 7.2 Nethermills Farm, NM4, pOSL photon counts across the site from the south (river) to the north (northern palaeochannel) with depth in $\mathrm{cm}$

probably just before or during the Early Holocene (before $c 9700 \mathrm{BC}$ ), from an active channel running to the north of the gravel ridge. It is probable, though unproven, that sand also accumulated in the southern sand sheet at this time, being fed by a channel close to, if not in, the position still occupied by the River Dee today. However, given that much of the sediment in the southern sand sheet accumulated much later, it is likely that by the time of Mesolithic occupation, activity at Nethermills took place on a terrace surface that was only rarely inundated by floods.

This interpretation is supported by other investigation in the northern channel. While Ewan's pollen-analytical study indicated that the basal peat is Early Holocene in date (before $c 9700$ вC; Ewan 1981; Tipping 2007; Wickham-Jones et al 2017), the radiocarbon determination of Betula (birch) charcoal in TP69 (from the loam fill of the same palaeochannel) yielded a date of $c 3900$ вС (SUERC 93098; see Table 7.2 below). It would seem, therefore, that this channel had begun to dry early on in the Holocene and, though conditions remained damp, only the highest floods deposited sediment on the terrace surface by this stage. The wider analysis of the local woodland indicates that generally dry conditions persisted throughout the Holocene, able to support Corylus and later Quercus (Ewan 1981).

\subsubsection{Excavation results}

A full Data Structure Report of the Nethermills test pitting has been submitted to the Aberdeenshire Historic Environment Record and Historic Environment Scotland.

Test pit locations were identified prior to excavation (Illus 7.3) from a stratified random sample across the field in order to provide unbiased coverage across the field. A total of 150 pits were laid out, each measuring $2 \mathrm{~m} \times 2 \mathrm{~m}$, of which 102 were dug with a mini-digger (Illus 7.4), under archaeological supervision, in order to remove the upper layer of the ploughsoil (labelled upper topsoil), down to an arbitrary layer about $100 \mathrm{~mm}$ above the subsoil (estimated with a probe or from 


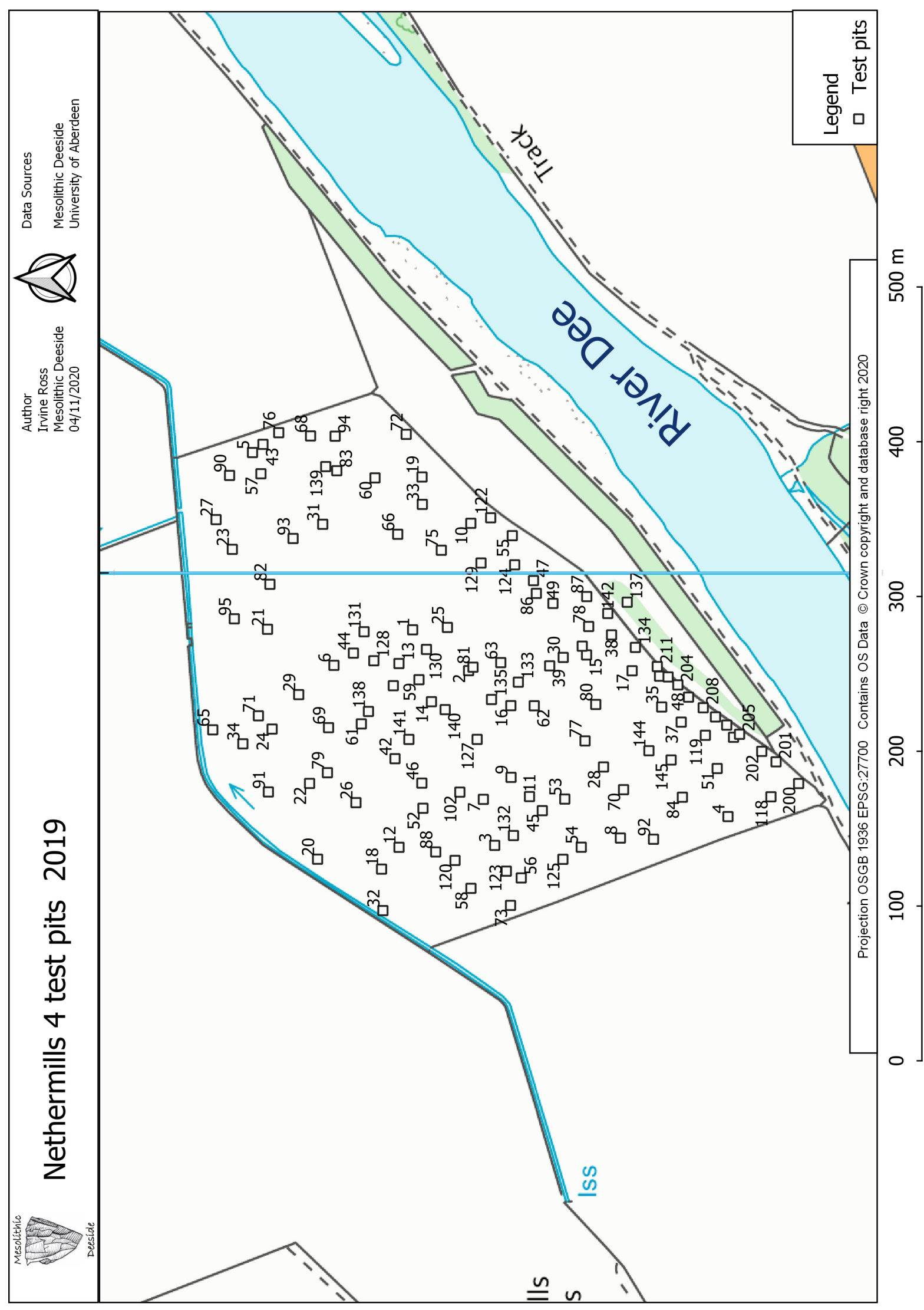

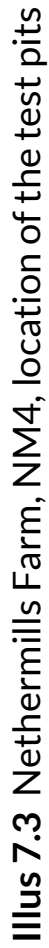




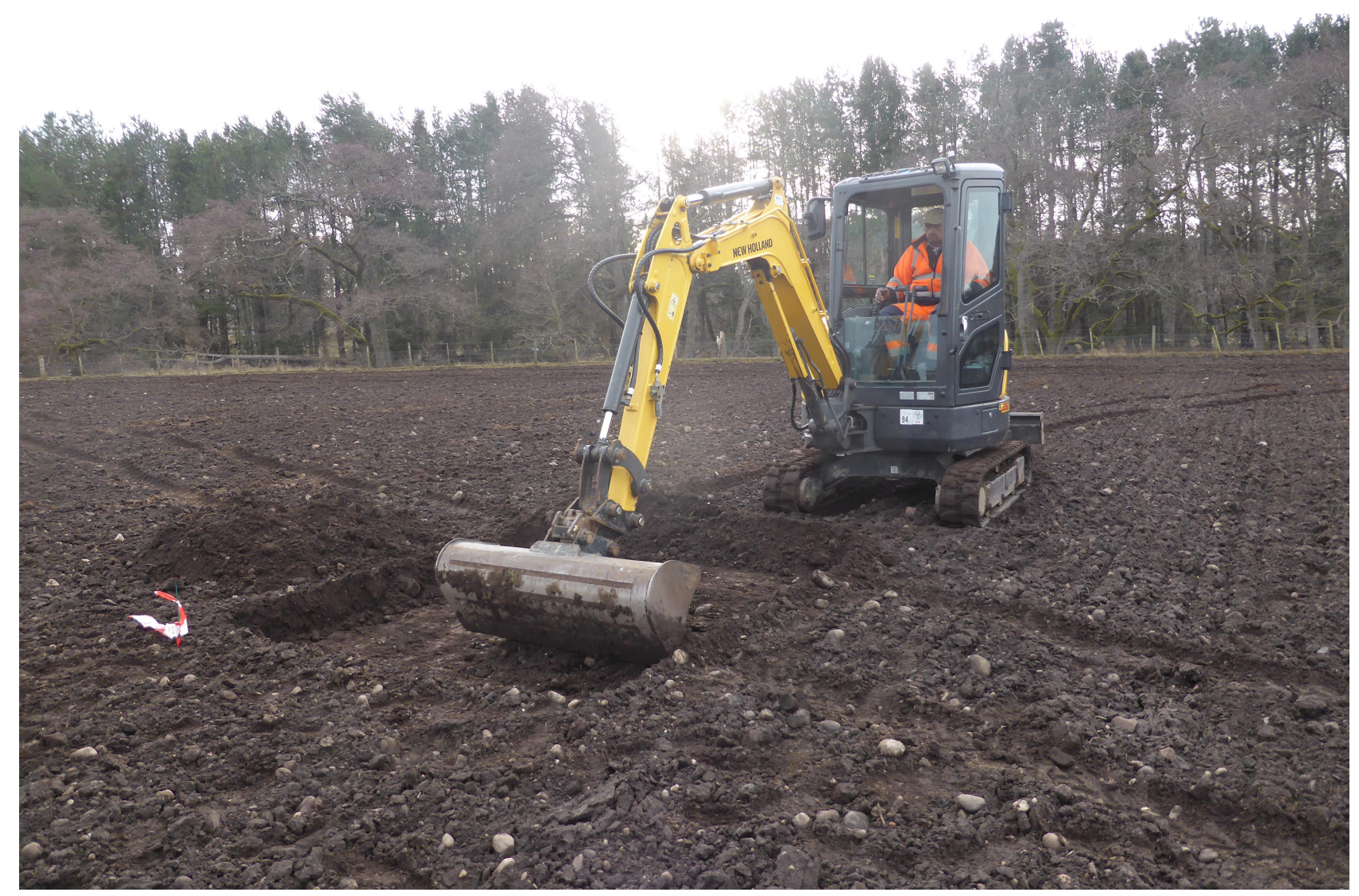

Illus 7.4 Nethermills Farm, NM4, digger opening a test pit

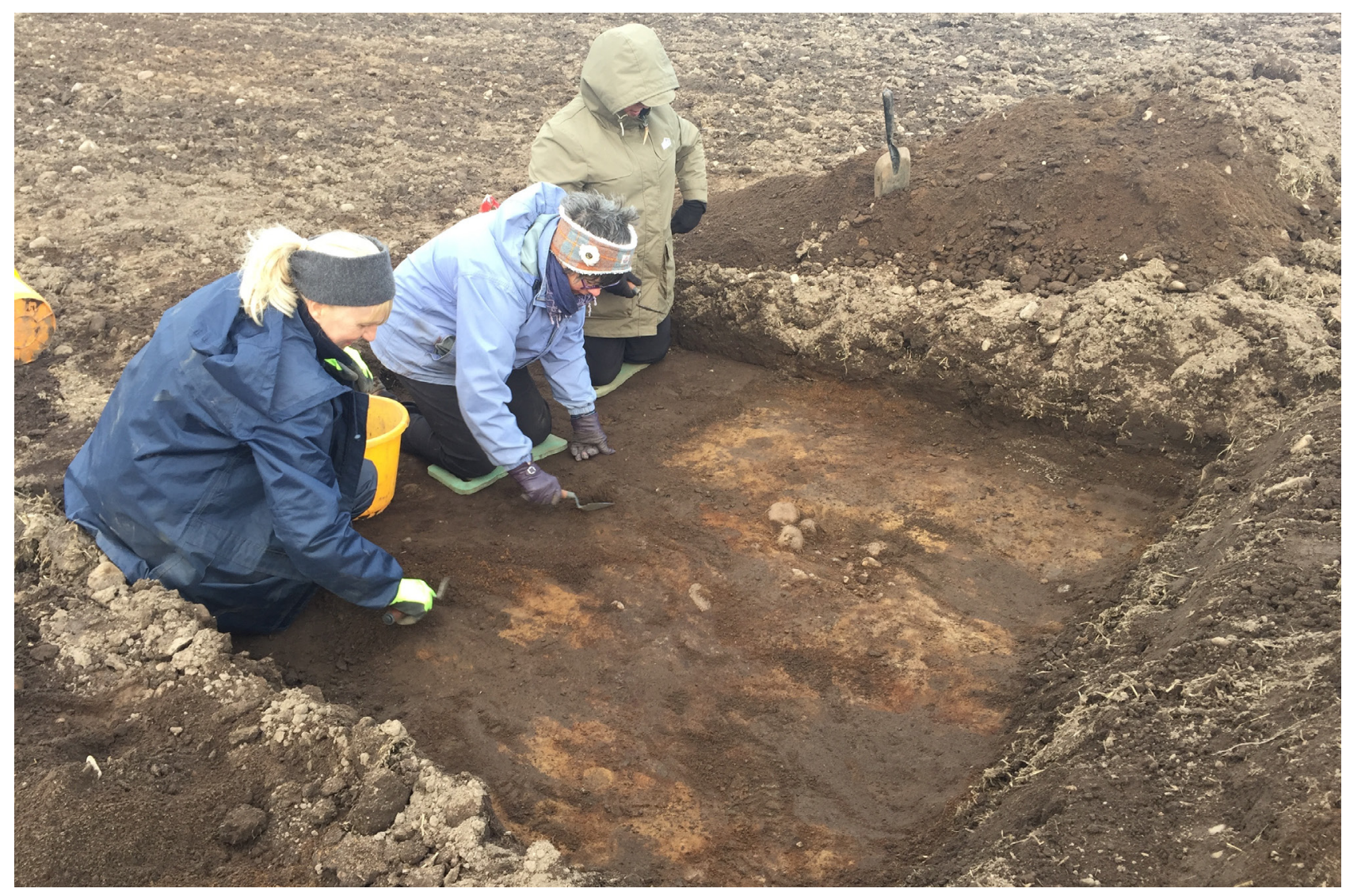

Illus 7.5 Nethermills Farm, NM4, cleaning down to the bottom of the ploughsoil 
adjacent pits). After this each test pit was hand cleaned (labelled lower topsoil) down to the bottom of the ploughsoil (Illus 7.5). Two standard buckets (roughly 28 litres in total) from both upper and lower topsoil within each test pit were dry sieved through a $5 \mathrm{~mm}$ mesh, and any worked lithics and other finds removed. Finds were catalogued and then returned to the test pit to be buried with the backfill. Only exceptional material was retained; defined as typologically distinctive material such as pieces possibly indicative of a Late Upper Palaeolithic date.

Once the surface of the subsoil had been identified and cleaned, all possible features were half-sectioned and excavated by hand. All spoil was dry sieved. Features not deemed to be natural or animal in origin were planned and photographed. Finds were catalogued and retained. Test pits were extended where it was deemed necessary in order to explore the subsoil features. One larger trench $(202,12 \mathrm{~m} \times 3 \mathrm{~m})$ was opened in the south of the site to examine a series of possible features (Illus 7.6) and, in addition, ten deeper pits were excavated into stratified sediment for geoscience purposes.
Many test pits revealed evidence of intense agricultural activities at their base. Much of this comprised modern (20th- and 21st-century) plough marks (Illus 7.7) but older (possibly medieval) evidence of rig and furrow cultivation was also present (Illus 7.8). Other features were often agricultural in origin. In TP202, the larger trench opened to investigate a cluster of lithic finds, all of the anomalies were animal or agricultural in origin. Nevertheless, five test pits revealed potentially older features which were all halfsectioned, sampled and recorded (Illus 7.9, 7.10, $7.11 \& 7.12$; Table 7.1). This excavation resulted in the selection of three samples for radiocarbon assay, two from TP68 and one from TP69 (Table 7.2).

TP68 lay towards the eastern edge of the field, near the boundary with NM5. A small cut feature (6801; Illus 7.10), visible below the lower ploughsoil, and itself $0.1 \mathrm{~m}$ deep (Illus 7.13), yielded a single piece of Salix (willow) and some Betula (birch) charcoal from flotation and this has been dated to 6830-6640 cal вс (SUERC-93093, 7868 \pm 31 вр;

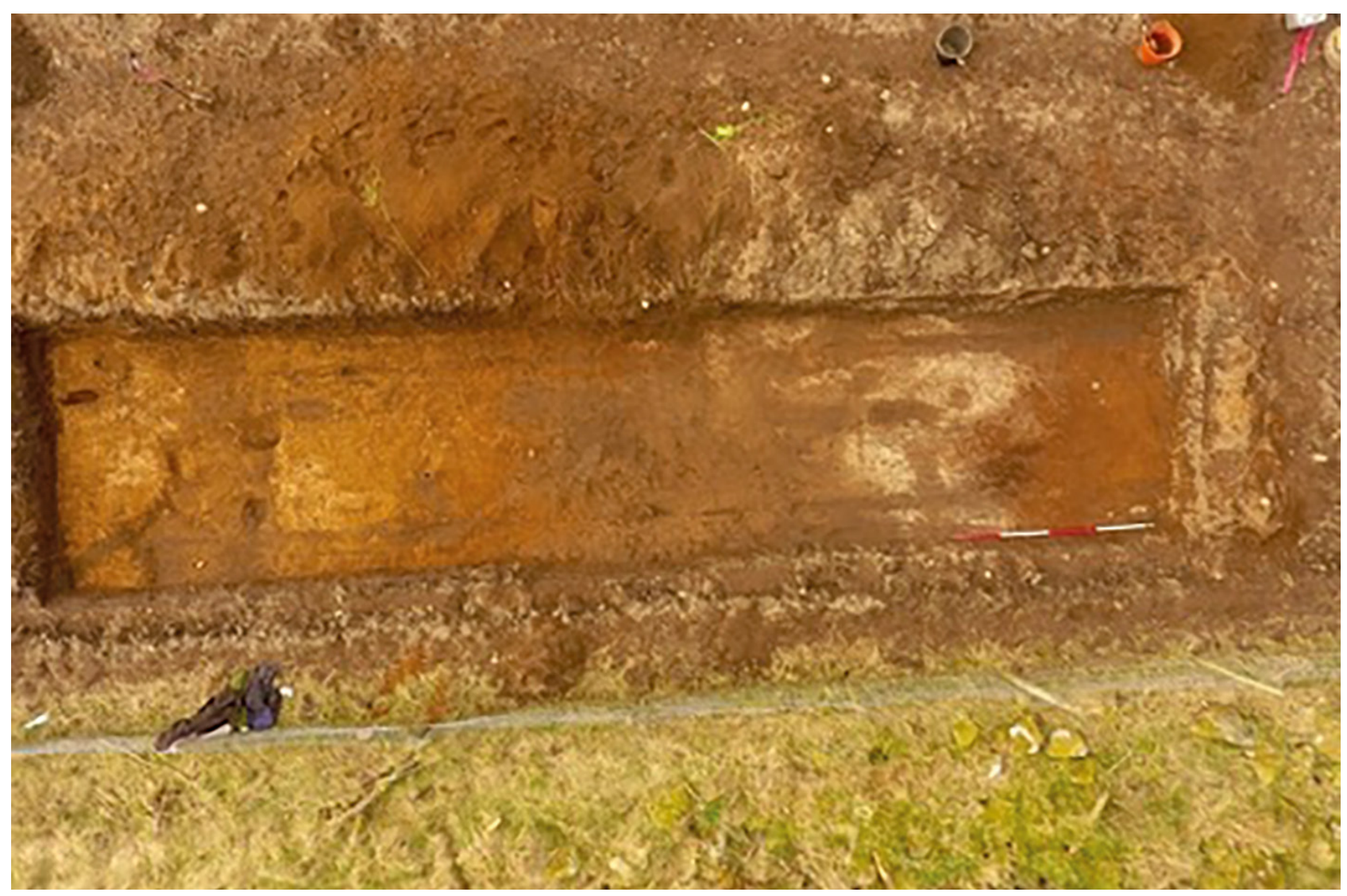

Illus 7.6 Nethermills Farm, NM4: TP202 opened as a larger trench at the south of the field to investigate the location of a cluster of lithics 
Table 7.1 Nethermills Farm 4, test pits with features of interest. Further information on the radiocarbon determinations is given in Table 7.2

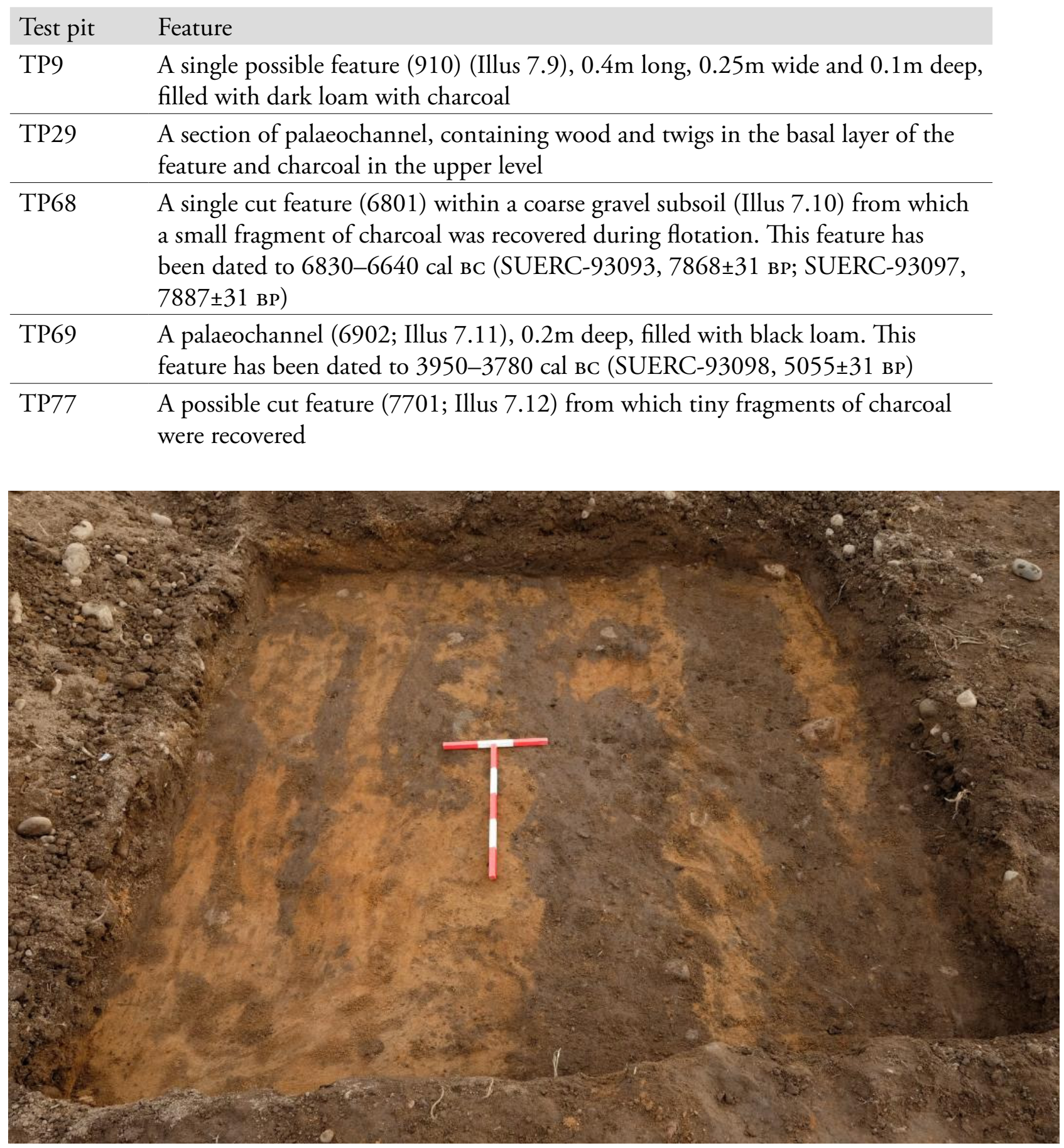

Illus 7.7 Nethermills Farm, NM4: TP10, modern plough marks in the sandy natural subsoil, from the north

SUERC-93097, 7887 \pm 31 вр). While it was not possible to interpret Feature 6801, this is a classic date for a narrow-blade Mesolithic lithic assemblage such as that from Nethermills Farm and it was reassuring to note that some indication of Mesolithic deposits had survived in addition to the stone tools.
TP69 was cut across the edge of a palaeochannel towards the north of the field (Illus 7.3, $7.11 \&$ 7.13), and a sample of Betula (birch) charcoal from the black loam fill has been dated to 3950-3780 cal вс (SUERC-93098, 5055 \pm 31 вP). This date lies within the Early Neolithic and suggests that the palaeochannel was accumulating peat at this time. 


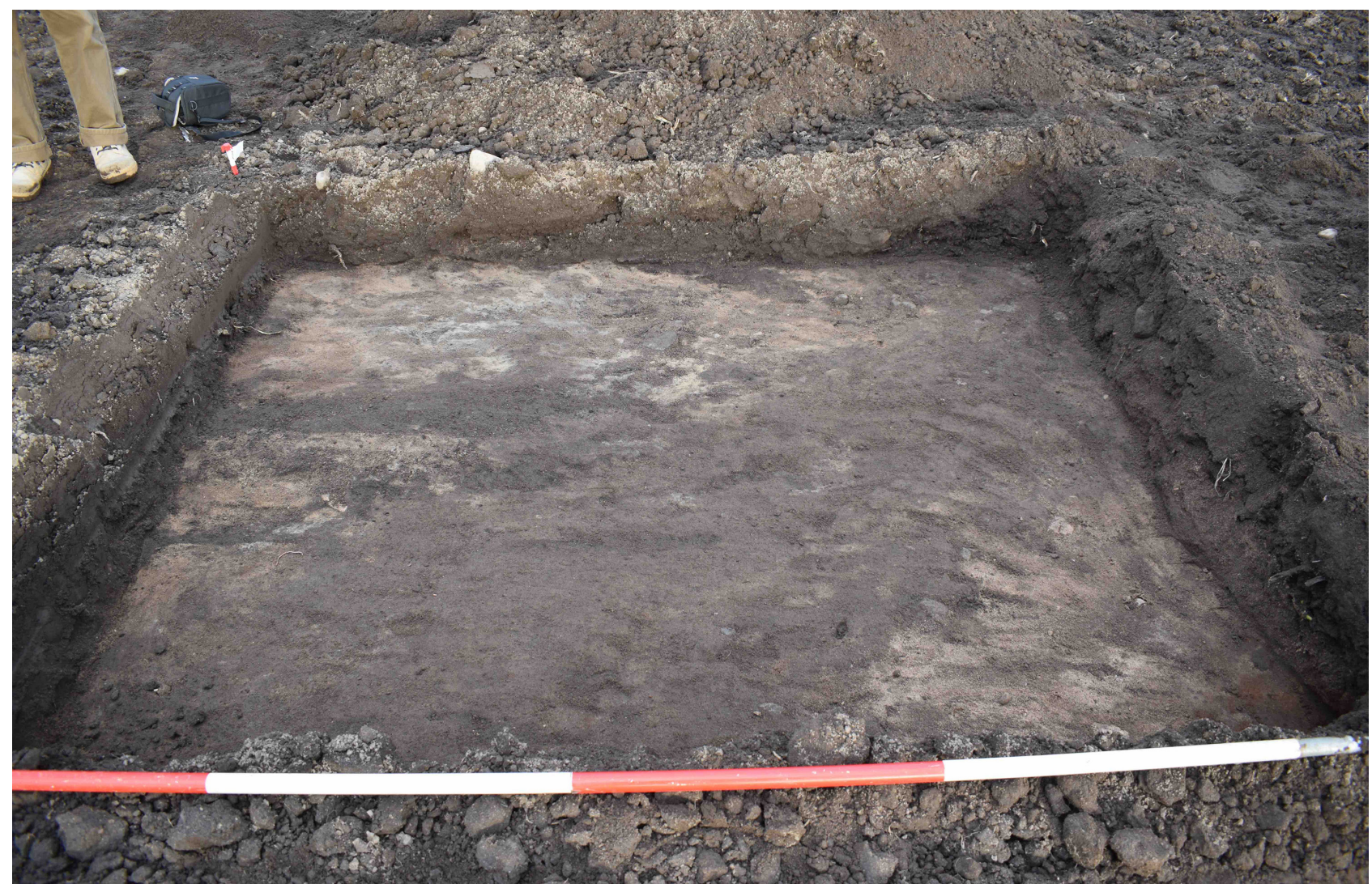

Illus 7.8 Nethermills Farm, NM4: TP37, south-east/north-west furrow from the west

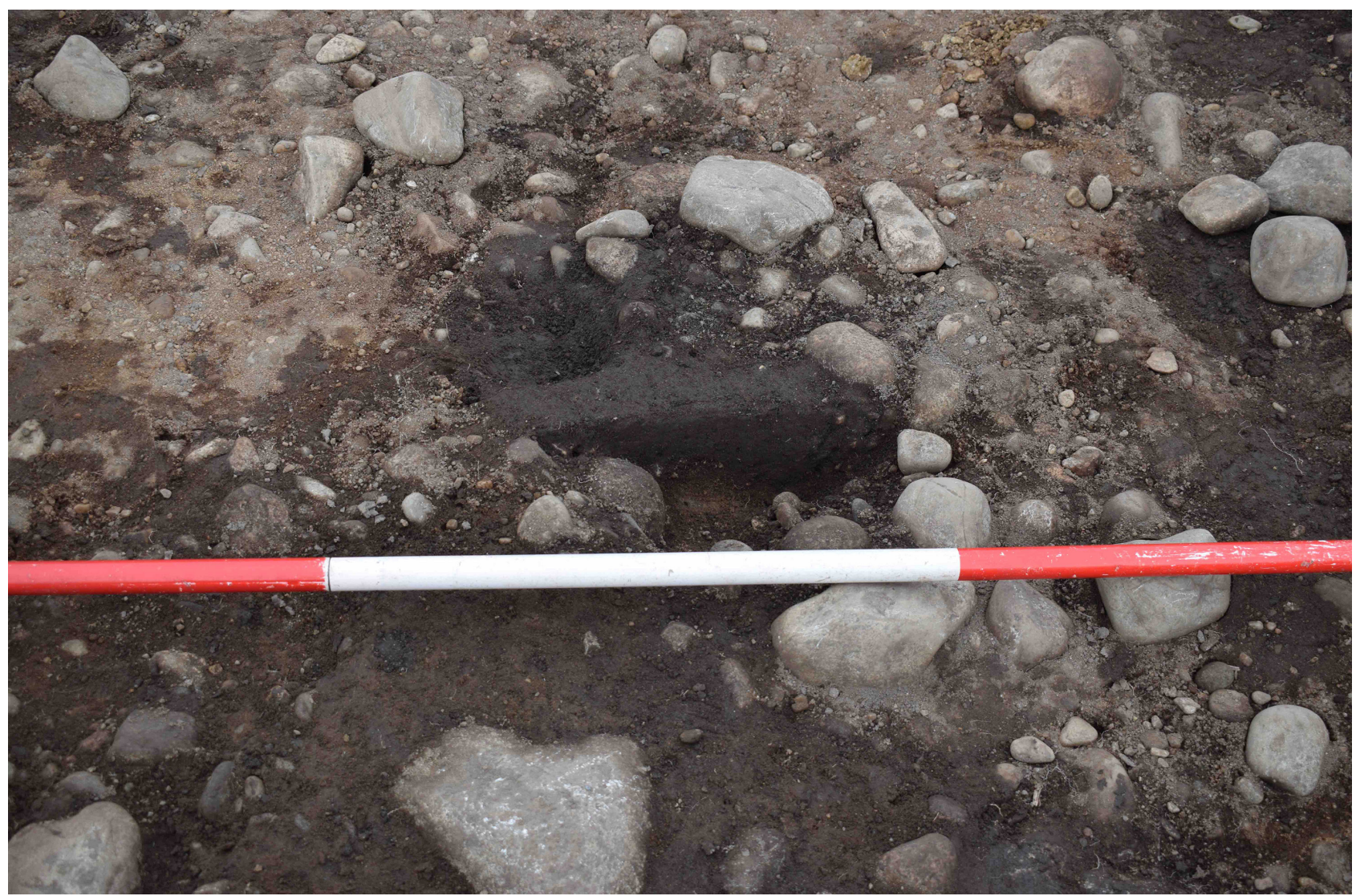

Illus 7.9 Nethermills Farm, NM4: TP9, Feature 910, from the west 


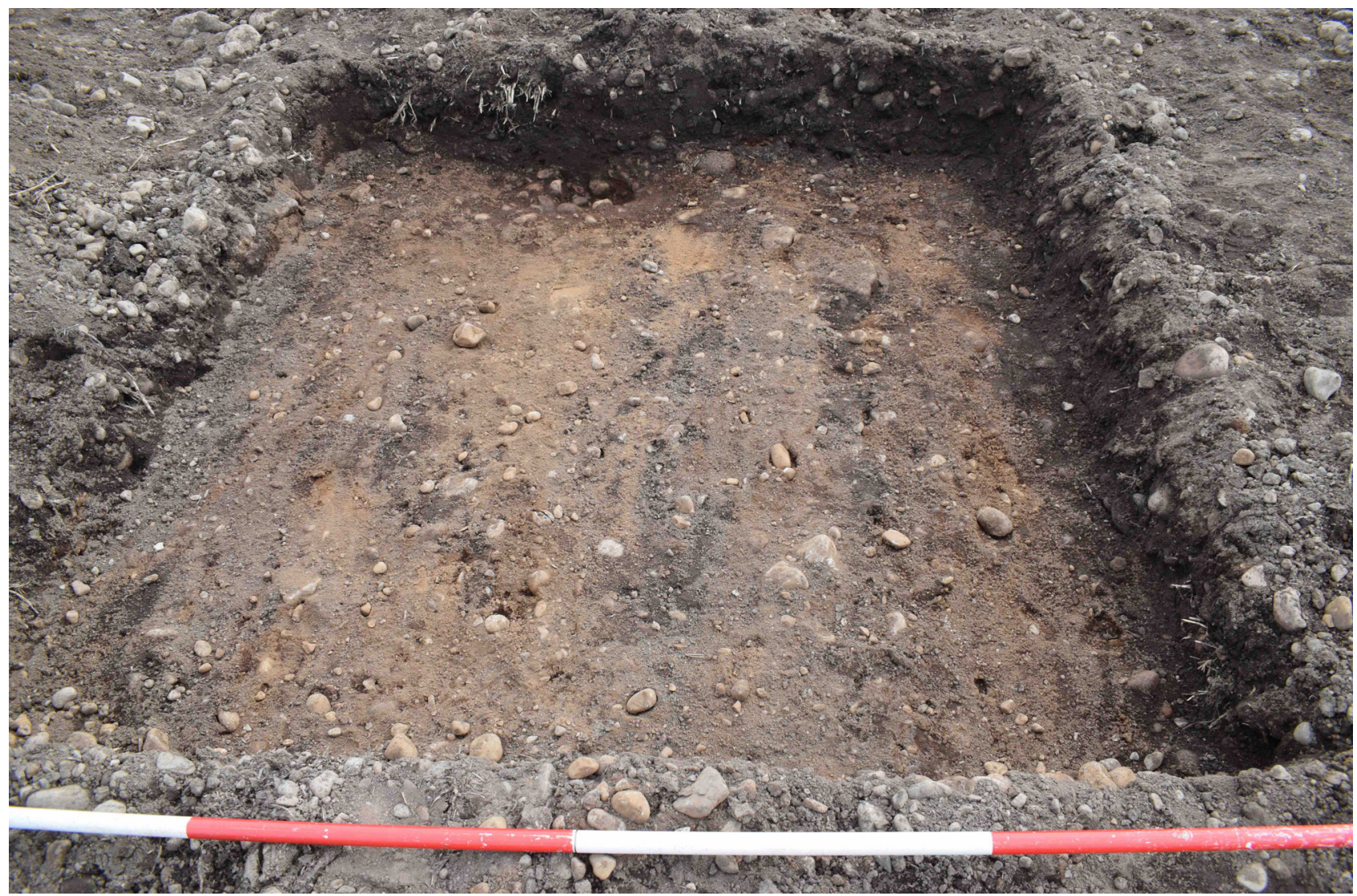

Illus 7.10 Nethermills Farm, NM4: TP68, gravel subsoil with Feature 6801, from the north



Illus 7.11 Nethermills Farm, NM4: TP69, palaeochannel from the south-east 


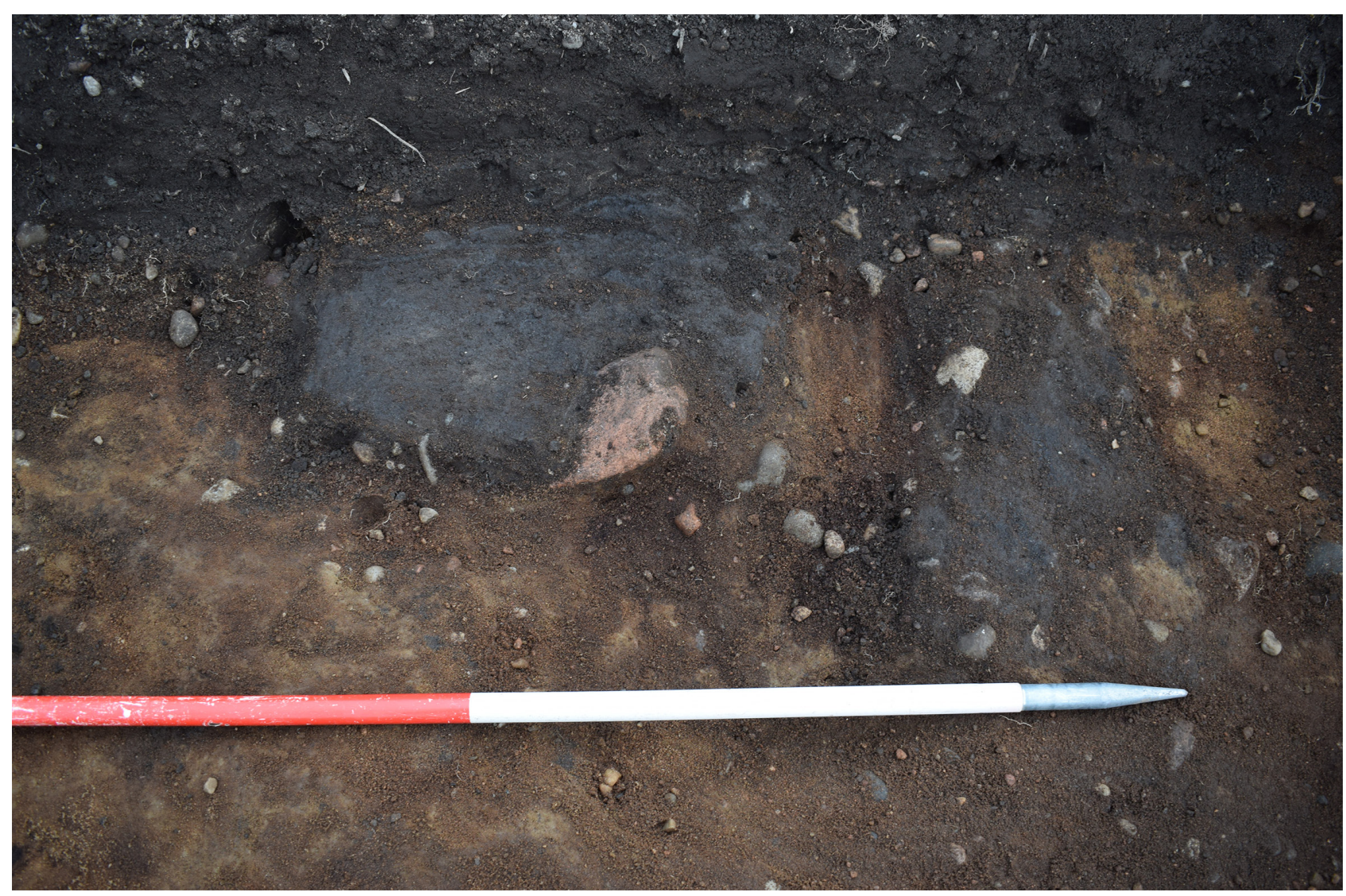

Illus 7.12 Nethermills Farm, NM4: TP77, possible Feature 7701, from the north

Table 7.2 Nethermills Farm 4: radiocarbon determinations

\begin{tabular}{|c|c|c|c|c|c|c|}
\hline Lab no. & Material & Context/sample & $\begin{array}{c}\text { Radiocarbon } \\
\text { age (BP) }\end{array}$ & $\begin{array}{l}\delta^{13} \mathrm{C} \\
(\% o)\end{array}$ & $\begin{array}{l}\text { Calibrated date } \\
\text { range }(95 \% \\
\text { confidence) } \\
\text { (cal BC) }\end{array}$ & $\begin{array}{l}\text { Calibrated date } \\
\text { range }(68 \% \\
\text { confidence) } \\
\text { (cal вс) }\end{array}$ \\
\hline $\begin{array}{l}\text { SUERC-93093 } \\
\text { (GU55100) }\end{array}$ & $\begin{array}{l}\text { Charcoal: } \\
\text { Betula sp }\end{array}$ & $\begin{array}{l}\text { TP } 68, \text { fill } 6802 \\
\text { of cut feature } \\
6801\end{array}$ & $7868 \pm 31$ & -24.8 & 6830-6640 & $6750-6650$ \\
\hline $\begin{array}{l}\text { SUERC-93097 } \\
\text { (GU55101) }\end{array}$ & $\begin{array}{l}\text { Charcoal: } \\
\text { Salix sp }\end{array}$ & $\begin{array}{l}\text { TP } 68, \text { fill } 6802 \\
\text { of cut feature } \\
6801\end{array}$ & $7887 \pm 31$ & -24.7 & $7000-6640$ & $6770-6660$ \\
\hline $\begin{array}{l}\text { SUERC-93098 } \\
\text { (GU55102) }\end{array}$ & $\begin{array}{l}\text { Charcoal: } \\
\text { Betula sp }\end{array}$ & $\begin{array}{l}\text { TP69, loam } \\
\text { fill } 6902 \text { of } \\
\text { palaeochannel }\end{array}$ & $5055 \pm 31$ & -29.6 & $3950-3780$ & $3940-3800$ \\
\hline
\end{tabular}




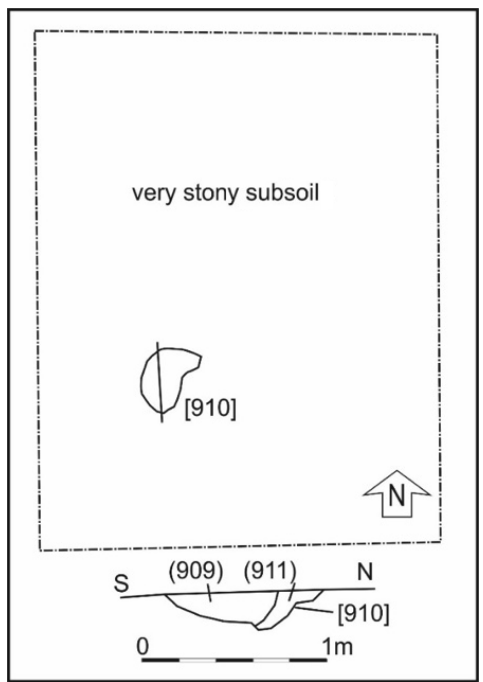

TP9 Feature 910, and section

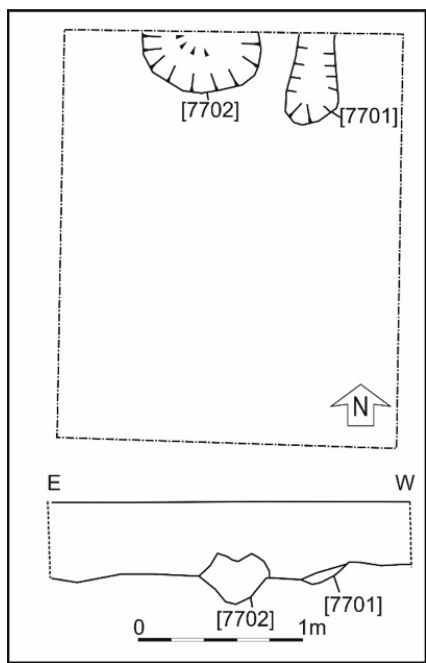

TP77 Possible features 7701 and 7702 and sections

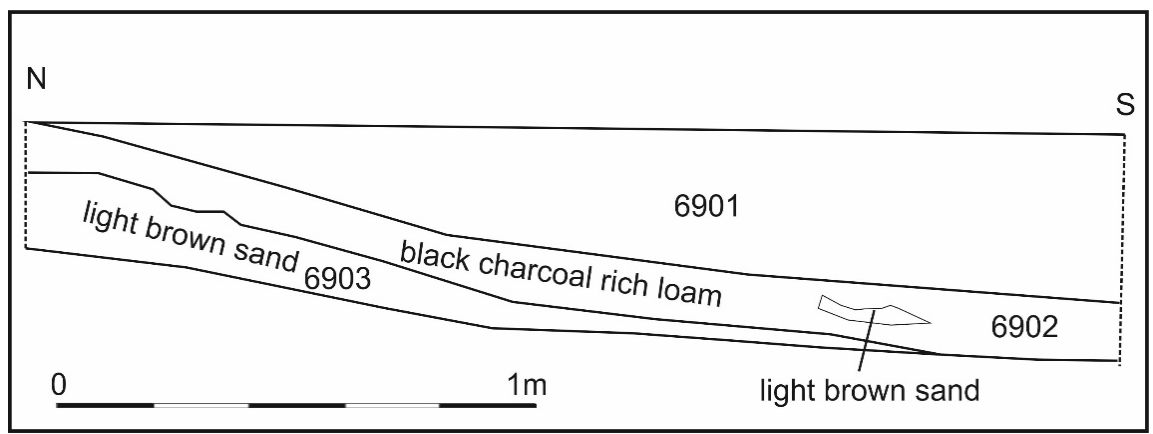

TP69, Section through the palaeochannel

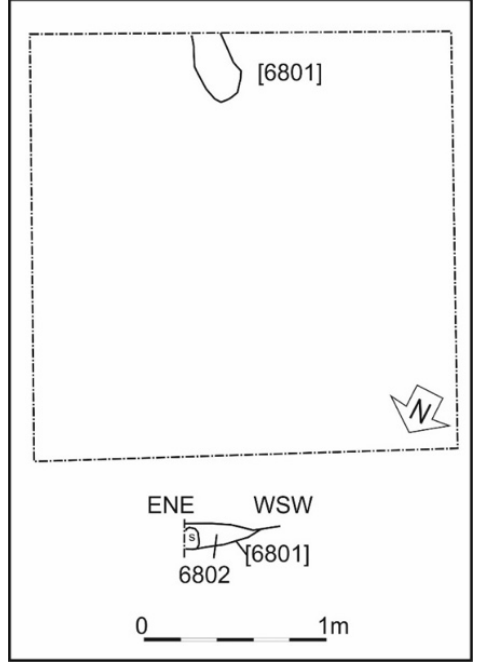

TP68, Feature 6801, and section 